PII: S0301-0082(98)00033-1

\title{
EXPERIMENTAL STRATEGIES TO PROMOTE AXONAL REGENERATION AFTER TRAUMATIC CENTRAL NERVOUS SYSTEM INJURY
}

\author{
CHRISTINE C. STICHEL* and HANS WERNER MÜLLER \\ Molecular Neurobiology Laboratory, Department of Neurology, University of Düsseldorf, Moorenstraße 5, \\ 40225 Düsseldorf, Germany
}

(Received 20 January 1998)

\begin{abstract}
A damage or pathological process that destroys the continuity of axons in the mature central nervous system (CNS) has devastating consequences and produces lasting functional deficits. One of the major challenges in this field is to stimulate the regrowth of severed axons and reconstruction of pathways. Recent progress in molecular and cell biology has resulted in an explosion of knowledge on factors in the adult CNS being nonsupportive or even actively inhibitory to axonal regrowth. The new findings have a strong impact on the development of new therapeutic concepts directed to stimulate axonal regeneration. They give rise to cautious optimism, showing that under some circumstances repair of a CNS lesion is possible. In this review the authors summarize the current knowledge on the factors and mechanisms involved in regeneration failure and provide an overview of the current therapeutic approaches that may enable effective CNS regeneration in the future. (C) 1998 Elsevier Science Ltd. All rights reserved
\end{abstract}

\section{CONTENTS}

1. Introduction

2. Molecular and cellular changes at the lesion site

2.1. Molecular changes

2.2. Responses of nonneuronal cells

2.3. Response of neurons

3. Hypotheses to explain failure of axonal regeneration in the adult mammalian CNS

3.1. Intrinsic determinants

3.2. Extrinsic determinants

4. Requirements for the structural and functional recovery of injured axons

5. Experimental approaches to promote axonal regeneration

5.1. Overexpression of neurite-growth associated proteins

5.2. Delivery of neurotrophic substances

5.3. Grafting

5.3.1. Acellular bridges

5.3.2. Fetal CNS tissue

5.3.3. Peripheral nerve/Schwann cells

5.3.4. Astroblasts

5.3.5. Olfactory bulb ensheathing cells

5.3.6. Microglial cells

5.4. Neutralization of neurite growth inhibitors

5.5. Reduction of scarring

5.6. Electric fields

5.7. Combined strategies

6. Clinical perspectives

Acknowledgements

References 


\section{ABBREVIATIONS}

$\begin{array}{ll}\text { BDNF } & \text { Brain-derived neurotrophic factor } \\ \text { CNS } & \text { Central nervous system } \\ \text { CNTF } & \text { Ciliary neuronotrophic factor } \\ \text { CSPG } & \text { Chondroitin sulphate proteoglycan } \\ \text { ECM } & \text { Extracellular matrix } \\ \text { FGF } & \text { Fibroblast growth factor } \\ \text { GABA } & \gamma \text {-Aminobutyric acid } \\ \text { GAP-43 } & \text { Growth associated protein } 43 \mathrm{kDa} \\ \text { GFAP } & \text { Glial fibrillary acidic protein } \\ \text { HSPG } & \text { Heparan sulphate proteoglycan } \\ \text { IGF } & \text { Insulin-like growth factor } \\ \text { KSPG } & \text { Keratan sulphate proteoglycan } \\ \text { MAG } & \text { Myelin-associated glycoprotein }\end{array}$

1. INTRODUCTION

Mechanical injury to adult mammalian central nervous system (CNS) may result in widespread functional losses and in permanent neurological deficits. Spinal cord injury is one of the prominent examples of such a traumatic insult leading to permanent disability with loss of sensory, motor and reflex activities [for reviews see Adams and Victor (1985) and Schwab and Bartholdi (1996)]. The severe clinical consequences are due to the fact that, in contrast to most other tissues, the CNS lacks the ability to reconstitute itself by neuronal cell proliferation and fails to regrow severed axons. Axotomized nerve fibers within the CNS show an initial growth response but after a short distance this regrowth ceases. The poor axonal regeneration in mammalian CNS stands in sharp contrast with the situation observed in fish, amphibia or mammalian peripheral nervous system (PNS) and immature mammalian CNS. The latter systems possess significant regenerative capacities and are able to restore neuronal function after lesion (Ramón y Cajal, 1928; Gaze, 1970; Kiernan, 1979; Cohen et al., 1988; Stürmer et al., 1992; Sharma et al., 1993; Davis and McCellan, 1994; Lang et al., 1995; Li et al., 1995).

At the beginning of this century, the regeneration failure of CNS was a dogma and differentiated mammalian CNS neurons were considered inherently incapable of regrowth. However, since the pioneering studies of Ramón y Cajal (1928) and those of Aguayo and colleagues (David and Aguayo, 1981; Duncan et al., 1981) it has been well established that CNS neurons have the capacity to regrow axons given a suitable environment. The latter authors have shown that lesioned CNS axons grow successfully into a peripheral nerve (PN) implant but cease growing as they enter the CNS tissue. These PNS-CNS grafting experiments have been instrumental in reversing the previous dogma. A more optimistic outlook began to evolve during the last two decades and a number of studies were performed to identify inhibiting factors responsible for axonal regeneration failure and to develop effective experimental strategies to stimulate structural and functional repair of lesioned CNS.

The present review briefly summarizes fundamental molecular and cellular reactions to traumatic injury and their putative involvement in regener-

$\begin{array}{ll}\text { MBP } & \text { Myelin basic protein } \\ \text { MHC } & \text { Major histocompatibility complex } \\ \text { NCAM } & \text { Neural cell adhesion molecule } \\ \text { NGF } & \text { Nerve growth factor } \\ \text { NI35/250 } & \text { Neurite growth inhibitor } 35 / 250 \mathrm{kDa} \\ \text { NT } & \text { Neurotrophin } \\ \text { NTF } & \text { Neurotrophic factor } \\ \text { PDGF } & \text { Platelet-derived growth factor } \\ \text { PN } & \text { Peripheral nerve } \\ \text { PNS } & \text { Peripheral nervous system } \\ \text { TEN } & \text { Tenascin C } \\ \text { TGF } & \text { Transforming growth factor } \\ \text { WGA-HRP } & \text { Wheat germ agglutinin horseradish } \\ & \text { peroxidase }\end{array}$

ation failure, reviews recent progress in the development of regeneration promoting strategies and discusses their possible therapeutic application.

\section{MOLECULAR AND CELLULAR CHANGES AT THE LESION SITE}

\subsection{Molecular Changes}

Traumatic injuries of the CNS initiate a complex sequence of pathophysiological responses at the lesion site [for reviews see Hall (1989); Hilton (1994); McIntosh (1994); Schwab and Bartholdi (1996); Tymianski and Tator (1996)]. The first gross observation immediately after injury is the extravasation of blood into the lesion site due to disruption of blood vessels. The lesion site becomes filled with a plug of haematogenous material, including monocytes, lymphocytes and inflammatory mediators. As a result of vascular spasm and disruption there is local ischemia, hypoxemia and hypoglycaemia. Vasogenic edema becomes evident and contributes to necrosis of cells. Likewise at this very early time after lesion a profound change in the composition of the extracellular fluid is observed. Excitatory amino acids like glutamate and aspartate are secreted; iron is released from intracellular storage proteins and catalyzes the generation of oxygen radicals; excess of calcium and potassium appears and growth factors as well as proteases accumulate within the wound. All these factors form an interactive reaction cascade leading to the death of neurons and glial cells and the degeneration of axons at the site of injury.

Besides these acute changes in the extracellular milieu the lesion-induced transition of glial cells from the resting to the activated state (see later) is associated with the expression of new molecules as well as the upregulation of factors that are found at lower levels in normal brain [for reviews see Brodkey et al. (1993) and Eddleston and Mucke (1993)]. Astrocytes are particularly very active early after injury, and among the first molecular changes are the increase in glial fibrillary acidic protein (GFAP) (Schiffer et al., 1986; Condorelli et al., 1990) and the induction of major histocompatibility complex (MHC) antigens (Lee et al., 1990; Neumann et al., 1996). Further, astrocytic molecules 
expressed after injury comprise diffusible polypeptide factors, membrane-associated macromolecules, extracellular adhesion molecules and membrane proteins. Prominent examples of such lesion-induced molecules [for review see Brodkey et al. (1993)] are the glycoproteins laminin (Liesi et al., 1984; Giftochristos and David, 1988; Sosale et al., 1988) and fibronectin (Egan and Vijayan, 1991), different types of collagen (Feringa et al., 1980; Maxwell et al., 1984), proteoglycans (Giftochristos and David, 1988; Bovolenta et al., 1993; Lips et al., 1995; Stichel et al., 1995a; Levine, 1996), tenascin C (TEN-C) (Chuong and Chen, 1991; Laywell et al., 1992; Ajemian et al., 1994; Lips et al., 1995; Zhang et al., 1995) and neurotrophic factors (NietoSampedro et al., 1983; Needels et al., 1986; Asada et al., 1996). These molecules differ largely in their extracellular distribution. Laminin and collagen type IV, which are generally considered to provide a particularly attractive substratum for axonal elongation (Carbonetto et al., 1983; Edgar et al., 1984), are mainly organized as basal lamina (basement membrane) (Timpl and Brown, 1996) around lesioninduced blood vessels (Giftochristos and David, 1988; Hagg et al., 1989; Shigematsu et al., 1989; Stichel and Müller, 1994b) and as part of the glia limitans (Risling et al., 1993) in the wound, while TEN-C and proteoglycans are widespread in the extracellular matrix (ECM) and within astrocytes (Bartsch et al., 1992; Laywell et al., 1992; Pindzola et al., 1993; Ajemian et al., 1994; Mitrovic et al., 1994; Lips et al., 1995). Following lesion astrocytes also remodel the composition and architecture of their cellular membrane. The expression of the neural cell adhesion molecule (NCAM) (Chuong and Chen, 1991; Nait Oumesmar et al., 1995) and the number of orthogonal arrays and gap junctions (Wolburg and Kästner, 1984), that are determinants of cell-cell communication, are significantly increased.

Besides astrocytes, activated microglia and monocytes/macrophages also exhibit strong secretory properties. They secrete a variety of cytokines, degradative enzymes, such as proteases, and small bioactive molecules, such as leukotrienes and superoxide [for reviews see Nathan (1987); Perry and Gordon (1988); Auger and Ross (1992) and Banati et al. (1993)].

The molecular response to injury is complex and results in a complete reorganization of the ECM. The composition of the ECM is highly dynamic, depends on the type of injury and changes continuously. Whether and how the ECM components contribute to the neuronal response has to be evaluated and will add to our understanding of lesion-induced neuronal degeneration and regeneration processes.

\subsection{Responses of Nonneuronal Cells}

The acute phase of molecular changes of the extracellular environment is accompanied by a rapid activation of neuroglial and other nonneural cell types. Among the neuroglial cells, astrocytes and microglia/macrophages have received considerable attention in recent years. Both glial cell types exhibit a vigorous response to traumatic injury with marked hypertrophy, proliferation, migration and transition to a different morphological phenotype [for reviews see Maxwell et al. (1990a); Hatten et al. (1991); Landis (1994); Norenberg (1994); Moore and Thanos (1996); Ridet et al. (1997)]. Reactive gliosis is the result of this very early response to injury and is characterized by a dense web of interlacing glial processes that forms within a lesioned area. It is a hallmark of CNS lesion and a central element of the lesion scar which includes, in addition, invading fibroblasts, endothelial cells, oligodendrocytes, neutrophil granulocytes, lymphocytes and various ECM proteins (Lindsay, 1986; Reier and Houle, 1988). Several features of the postlesion glial responses are common to different lesion types and independent of the site of CNS lesion, such as:

1. the rapidity of the glial response (Maxwell et al., 1990a,b; Matsumoto et al., 1992; Stichel and Müller, 1994a);

2. the spatial distribution (Takamiya et al., 1988; Schmidt-Kastner et al., 1990; Berry et al., 1996b);

3 . the sequential activation of microglia/macrophages and subsequently astrocytes (Maxwell et al., 1990a; Schmidt-Kastner et al., 1990; Matsumoto et al., 1992; Stichel and Müller, 1994a); and

4. the transient absence of activated astrocytes in the perilesion area (Dusart and Schwab, 1994; Stichel and Müller, 1994a,b; Frank and Wolburg, 1996).

The first structural responses of endogenous glial cells have been already observed between 5 and 20 min postlesion (Phillips and Turner, 1991). This activation is a dynamic process and spreads from the epicenter of the lesion into the surrounding neuropil. Glial reactions peak at $c a$ 2-3 weeks postlesion, but macrophages as well as prominent phenotypic astrocytic changes are found up to 2 years after lesion (Stoll et al., 1989; Miklossy and Van der Loos, 1991; Stichel and Müller, 1994a,b). Such a long-term presence of activated glial cells indicates the persistence of metabolic changes, that might, in turn, influence the physiological properties of the affected brain area.

It is important to mention that besides these similarities in gliotic responses formation there are differences in the composition and molecular profile that vary according to the site of injury and the age of the animal [Wilkin et al. (1990); Hatten et al. (1991); Milligan et al. (1991); Alonso and Privat (1993); Fernaud-Espinosa et al. (1993); Hill et al. (1996); for review see Ridet et al. (1997)]. Dense gliosis is usually seen in areas of white matter, while gliosis in gray matter tends to be variable. Another interesting observation is that astroglial response to injury is much more moderate or even absent in neonates (Gearhart et al., 1979; Maxwell et al., 1990b; Trimmer and Wunderlich, 1990). Thus, the gliotic response to CNS lesion is surprisingly divers. Even within the same gliositic reaction the individual responses of reactive astrocytes, such as the expression of glycoproteins or proteoglycans, vary according to the relative position of the cell to the lesion center (Giftochristos and David, 1988; Bartsch et al., 1992; Laywell et al., 1992; Stichel and 
Müller, 1994a,b; Lips et al., 1995; Stichel et al., 1995a; Ridet et al., 1997).

Brain endothelial cells also take part in the cellular response to lesion and start to migrate actively and to proliferate (Shigematsu et al., 1989; Landis, 1994). Numerous blood capillaries with increased diameter and surrounded by basal laminae appear within the wound and constitute a dense vascular network (Sosale et al., 1988; Hagg et al., 1989; Blight, 1991; Stichel and Müller, 1994a,b). As a result blood circulation within the lesioned area is re-established. Vascular repair coincides with a permanent increase in the number of capillary profiles in the lesion area and with long-term changes of the blood-brain barrier including reduced astrocyte-endothelial cell association, expansion of perivascular space and prominent ECM deposits (Jaeger and Blight, 1997).

\subsection{Response of Neurons}

Lesions directly affecting gray matter may cause neuronal death either by direct physical insult (primary cell death) or indirectly by changes in the local environment (secondary cell death) and axonal lesion close to the cell body (retrograde cell death), respectively. However, if the lesion affects the white matter and occurs at some distances from the cell body most adult neurons survive axotomy. Since the present review focuses on strategies to promote axonal regeneration, we summarize the principle features of pathophysiological axon reactions (see Fig. 1).

When axons are completely severed or simply compressed (crush injury) they are essentially divided into two cytoplasmic compartments; the proximal and distal segment. The cut ends retract after injury leaving an intervening gap. Between 1 and 8 days after lesion the axoplasm begins to assume a more granular and dark appearance due to breakdown of cytoskeletal components. Shrinkage of axons, distension with multivesicular bodies as well as myelin retraction and disintegration are common pathological features after axonal lesion [Ramón y Cajal (1928); Steward et al. (1973); Richardson et al. (1982) and Maxwell et al. (1990a); for reviews see Povlishock et al. (1992) and Povlishock and Christman (1995)]. These axonal changes spread in a centrifugal fashion into anterograde and retrograde directions. The remaining axonal and myelin debris is phagocytosed by macrophages, activated microglia and astrocytes (Bignami and Eng, 1973; Bignami et al., 1981; Noske et al., 1982; Vinores and Herman, 1993), but normally removal of debris in the CNS is much slower than in the PNS (Bignami et al., 1981; Perry et al., 1987; Avellino et al., 1995). While the distal axonal stump disappears gradually, the proximal end exhibits morphological changes that lead to the emergence of growth cones. Within the first three weeks after lesion adult mammalian CNS axons show an initial growth response. However, sprouting axons extend only for very short distances, $\mathrm{ca}$ $1 \mathrm{~mm}$, before they cease growing and either degenerate (Richardson et al., 1982) or end locally at the lesion border (Reier et al., 1983; Stichel and Müller, 1994a; Anders and Hurlock, 1996). Although there are some exceptions of the rule (Wendt and Ayyad, 1987; Frisén et al., 1993), most sprouting axons in the adult mammalian CNS fail to enter the lesion site. However, from the latter observations it is clear that the lesion area itself is of prime importance in the context of regeneration failure.

\section{HYPOTHESES TO EXPLAIN FAILURE OF AXONAL REGENERATION IN THE ADULT MAMMALIAN CNS}

The key question of regeneration research since many years is for the mechanisms that are responsible for regeneration failure in adult mammalian CNS. Studies by Tello (1911) have already demonstrated the intrinsic capacity of mature CNS neurons to sustain long-distance axonal regeneration provided that their growth cones are placed in a favorable environment. Indeed, later investigations succeeded in identification of extrinsic factors and/ or structures that might arrest axonal regrowth. However, besides these extrinsic influences on regeneration it has become increasingly clear in the last years that intrinsic growth properties of the neurons are likely to be as important [for reviews see Fawcett (1992) and Caroni (1997)]. There is now evidence for differences in growth potentials of various neuronal types (Rossi et al., 1995) and a decline in regenerative axonal response with neuronal age (Chen et al., 1995; Li et al., 1995; Dusart et al.,

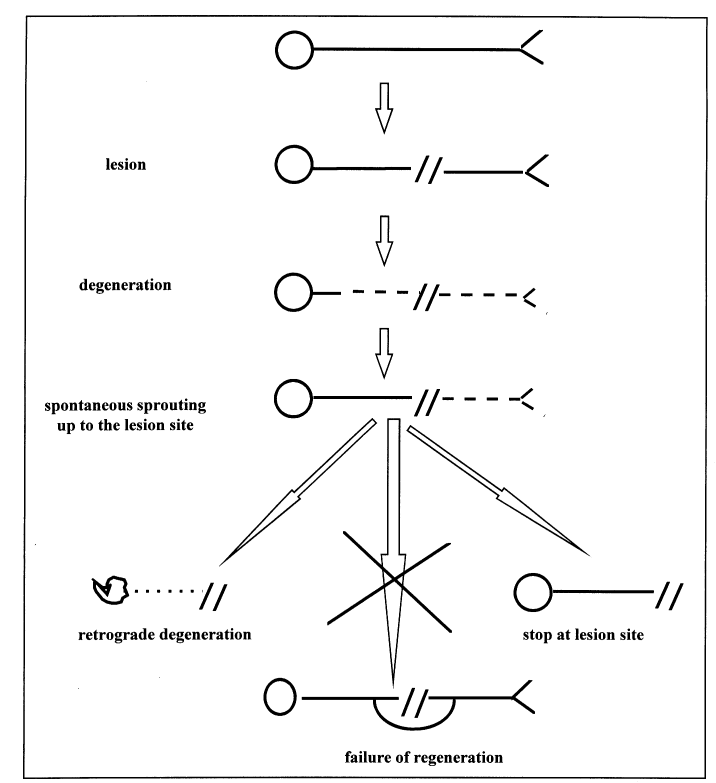

Fig. 1. Pathological changes of lesioned axons in adult mammalian CNS. This figure summarizes the lesioninduced changes after axonal disruption in the adult mammalian CNS. Axons first degenerate in the antero- and retrograde direction. Following, axons of the proximal stump spontaneously sprout up to the lesion site, where they stop abruptly. They never succeed in crossing or bypassing the lesion site but persist at the lesion border or degenerate secondarily. 
1997). While the characterization of determinants for regeneration failure is still not brought to an end, the concept emerges that axonal regeneration depends on the interplay between extrinsic cues and intrinsic properties of the lesioned neuron. Whether or not a mature neuron re-extends an axon depends on:

1. the ability to reexpress growth-related genes;

2 . the availability of neurotrophic factors and substrate molecules to which growing neurites may attach and extend;

3. the presence of growth-inhibiting molecules; and/ or

4. the formation of a glial scar.

\subsection{Intrinsic Determinants}

Neurons undergo changes in gene expression following axonal injury. Several studies have shown that the period of regrowth in axonal regeneration is characterized by the selective expression of a set of growth-associated proteins, immediate early genes and transcription factors, such as cfos, c-jun and KROX 24 (Jenkins et al., 1993; Robinson, 1994; Hayes et al., 1995; Honkaniemi et al., 1995; Wu, 1996; Herdegen et al., 1997), tubulin and actin (Bisby and Tetzlaff, 1992; Fournier and McKerracher, 1995) and the growth-associated protein GAP-43 (B-50/pp46/P-57) (Skene, 1989; Benowitz and Routtenberg, 1997). Clearly, nerve regrowth is controlled by the expression of specific proteins and implicates that the regulation of the corresponding genes might provide a basis for the stimulation of axonal regeneration. Especially, three proteins that are known to be upregulated after injury and/or downregulated at the end of the regeneration-permissive period have been considered to play a prominent competence role in neurite outgrowth, GAP-43 [Doster et al. (1991); Schaden et al. (1994); Aigner et al. (1995); Vaudano et al. (1995); for review see Benowitz and Routtenberg (1997)], a transcription factor of the immediate early gene family c-jun (Hüll and Bähr, 1994; for review see Herdegen et al., 1997) and the proto-oncogene bcl-2 [Chen et al. (1997); for review see Kroemer (1997)]. Overexpression of these genes supports regeneration of CNS axons at least during early perinatal period (Aigner et al., 1995; Chen et al., 1997), suggesting a function as intrinsic determinants for neurite regrowth. However, since neurons with $b c l-2$ overexpression or sustained c-jun expression may fail to exhibit axonal regeneration in mature CNS (Hüll and Bähr, 1994; Schaden et al., 1994; Chen et al., 1997) and certain populations of regenerating axons express little or no GAP-43 (Doster et al., 1991; Schaden et al., 1994), the expression of these growth-related genes is either not sufficient or not a prerequisite for axonal regeneration in the adult CNS. The latter observations might be indicative for additional extrinsic determinants of regeneration.

\subsection{Extrinsic Determinants}

Over the years several extrinsic conditions have been proposed to be adverse to CNS regeneration.
These can be divided into three basic features of the lesion-induced environment, that are, by no means, exclusive:

1. the absence of appropriate neurotrophic/neuritegrowth promoting factors required for the maintenance of axonal regrowth;

2. the presence of growth-inhibitory components; and

3. the scar acting as a physical impediment to axon elongation.

Considering the neurotrophic and neurite-promoting properties of Schwann cells in regenerating PNS, the inability of CNS neurons to regenerate has been attributed to the lack of neuritogenic/neurite-growth promoting molecules after CNS lesion (Tello, 1911; Ramón y Cajal, 1928; Liesi, 1985). However, NietoSampedro and others (Nieto-Sampedro et al., 1983; Needels et al., 1986; Asada et al., 1996) noted increased neurotrophic activity at CNS lesion sites, as well as a pronounced upregulation of fibroblast growth factor (FGF) (Frautschy et al., 1991; Logan et al., 1992) and ciliary neurotrophic factor (CNTF) (Ip et al., 1993b). Thus, the 'lack of trophic factors hypothesis' in the lesioned CNS may reflect an insufficient upregulation rather than the absence of those factors.

The observation that cultured neurons are unable to extend neurites into optic nerve explants even in the presence of optimal trophic factor conditions (Schwab and Thoenen, 1985) have led to the recent concept, that the inability of adult mammalin CNS neurons to regenerate is a result of the predominance of neurite growth-inhibiting molecules. There is now a substantial list of molecules that exert either repulsive or inhibitory effects on growing axons. The most prominent members of this group are the myelin and oligodendrocyte-associated inhibitor of neurite growth (NI 35/250), the myelin associated glycoprotein (MAG), the glycoprotein tenascin-C (TEN-C) and several proteoglycans such as chondroitin sulphate (CSPG), heparan sulphate (HSPG) and keratan sulphate proteoglycan (KSPG).

The myelin protein NI35/250 has been demonstrated to restrict axonal elongation after spinal cord lesion (Schnell and Schwab, 1990, 1993; Schnell et al., 1994) but is not a repellent component of the impermeable scar at the lesion site (Schnell and Schwab, 1993; Stichel et al., 1995b). Similarly, the myelin protein MAG strongly inhibits neurite outgrowth in vitro (McKerracher et al., 1994; Mukhopadhyay et al., 1994) but in vivo axons grow for long distances along or across myelinated fiber tracts or through degenerating myelin (Wictorin et al., 1992; Davies et al., 1993; Berry et al., 1996a; Stichel et al., 1996). Furthermore, mice deficient in MAG show no improved axonal regeneration (Bartsch, 1996). Thus, the myelin hypothesis of axon growth inhibition is ambiguous and does not offer a conclusive explanation for the regeneration failure in adult CNS.

Another potential candidate with growth-inhibitory properties is TEN-C, which is reexpressed and secreted by astrocytes after lesion (Laywell et al., 1992; Ajemian et al., 1994; Lips et al., 1995; Zhang 
et al., 1995). TEN-C is a member of the Ig superfamily of proteins and appears as a multifunctional glycoprotein with protein domains involved in neuron-binding, cell migration, neuron-repulsion and in the control of neurite growth [Götz et al. (1994); for review see Brodkey et al. (1993); Faissner and Steindler (1995)]. The effects of TEN-C depend on the form in which it is presented (Lochter et al., 1991; Taylor et al., 1993), as well as on the interactions with other ECM molecules (Marton et al., 1989; Faissner et al., 1990). Since TEN-C is also upregulated in regenerating PN (Martini et al., 1990) and is not expressed at the site of growth arrest in a CNS lesion (Lips et al., 1995), there is no clear-cut interpretation of growth-inhibitory vs growth-promoting effects and the contribution of this molecule to axon regeneration is still unresolved.

Proteoglycans comprise a heterogeneous group of molecules which are all composed of one or more glycosaminoglycan chains covalently linked to a core protein. Proteoglycans are widespread components of the ECM and a variety of these molecules are also expressed in the CNS [for reviews see Margolis and Margolis (1989); Kjellén and Lindahl (1991); Hardingham and Fosang (1992); Müller (1993) and Müller et al. (1996)]. In particular their inhibitory influences on neurite extension (Snow et al., 1990; Cole and McCabe, 1991; Snow and Letourneau, 1992; McKeon et al., 1995) as well as their involvement in boundary formation (Crossin et al., 1989; Flaccus et al., 1991; Katoh-Semba et al., 1995; Watanabe et al., 1995), ECM organization (Gallo and Bertolotto, 1990; Iozzo, 1997) their upregulation following brain injury (Giftochristos and David, 1988; McKeon et al., 1991; Bovolenta et al., 1993; De Witt et al., 1994; Lips et al., 1995; Stichel et al., 1995a; Szele et al., 1995; Levine, 1996) and deposition in regions of growth arrest (Davies et al., 1997) make them potential candidates for interactions with growing axons. There are many different proteoglycans of which some are conducive to neurite outgrowth and some are inhibitory. Moreover, similar to TEN-C the effects of proteoglycans depend on concentration, the timing and distribution of expression and the molecular interactions with a particular environment (Christner et al., 1980; Johnson-Green et al., 1992; Kresse et al., 1994; McKeon et al., 1995). While the lesioninduced re-expression of the distinct types of proteoglycans varies considerably and may thus lead to diverse actions on neurite growth, experiments that could establish a causal link between the presence of these constituents and neurite growth inhibition are lacking.

The third important extrinsic constraint that could limit regrowth of lesioned axons in the adult CNS is the formation of a prominent glial scar in the lesioned area. In almost all instances where CNS regeneration has been described, regenerating nerve fibers bypass or stop at the neuroglial scar (Reier et al., 1983; Schnell and Schwab, 1990, 1993; Lips et al., 1995; Stichel et al., 1995b; Anders and Hurlock, 1996) suggesting that the scar matrix is either improper in relation texture, surface and trophic or tropic factors to maintain axonal growth and/or may act as a mechanical barrier to axonal regeneration. However, there are conflicting reports regarding the mechanism responsible for the growth inhibition exerted by the glial scar. The above mentioned hypothesis of a mechanical inhibitory function of the scar has been questioned by the observations that:

1. in some brain regions and under certain conditions regrowing axons enter the scar and persist there for a long time (Frisén et al., 1993, 1995; Li and Raisman, 1995; Berry et al., 1996a);

2. the composition and influence of the scar depends on the type of insult and the region of the CNS that is affected [Alonso and Privat (1993); Garcia-Abreu et al. (1996); Hill et al. (1996); for review see Wilkin et al. (1990); Hatten et al. (1991) and Ridet et al. (1997)];

3 . the age and differentíation stage of astrocytes determine their capacity to either inhibit or support axonal growth (Smith et al., 1986; Smith et al., 1990); and

4. astrogliosis, a central component of glial scar, does not inhibit the advance of regrowing axons (Stichel and Müller, 1994b; Li and Raisman, 1995).

Nonetheless, regeneration is prevented by the lesion scar. While it is unlikely that the gliotic scar forms a physical barrier, changes in the molecular properties of the cells present in the scar, the absence of conducive factors in this region or the deposition of another impermeable scar component, the basal lamina, may account for the nonpermissive environment. Studies analysing the lesion-induced basal membrane formation, have proven that there is a clear spatio-temporal correlation between axonal growth arrest and the deposition of a dense collageneous basal membrane (Feringa et al., 1985; Stichel et al., 1998).

It has become clear that a plethora of lesioninduced extrinsic molecular factors may contribute to an inhospitable environment for axonal regeneration. Unfortunately, the direct influence of these factors on postlesion axonal regrowth is largely unclear and consequently their role in determining the success or failure of axonal regeneration remains speculative.

\section{REQUIREMENTS FOR THE STRUCTURAL AND FUNCTIONAL RECOVERY OF INJURED AXONS}

The precise regeneration of a lesioned projection in the CNS depends on a series of specific events, that can be viewed as a recapitulation of steps normally taken during development. Assuming that neurons survive the transection of their axons regeneration processes include:

1. regrowth (spontaneous sprouting) of the damaged axon;

2. passage through the lesion site;

3. elongation in the correct direction;

4. topographic reinnervation of the normal target; and

5. restoration of former electrophysiological properties [for reviews see Freed et al. (1985); Bähr and 


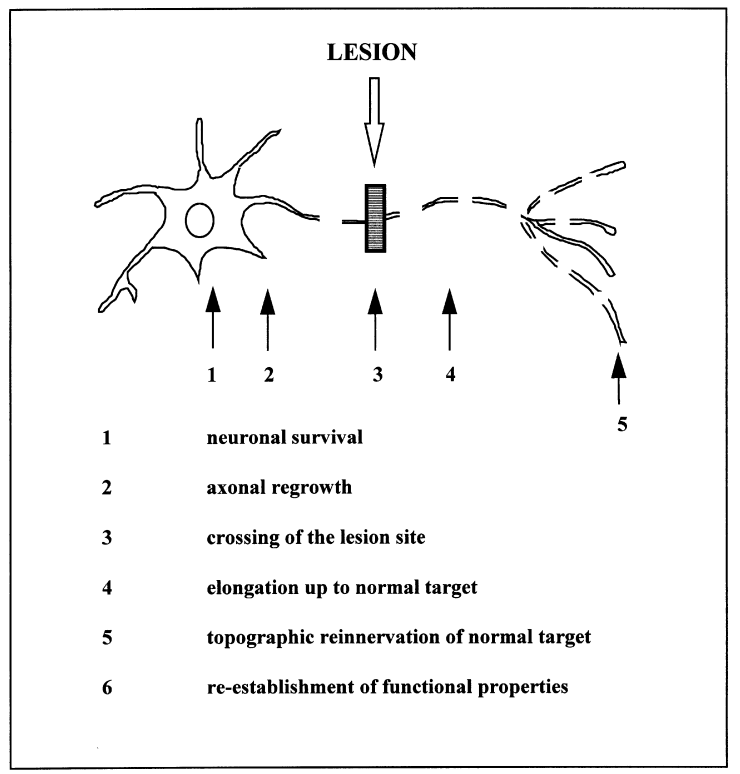

Fig. 2. Requirements for structural and functional repair of injured axons. Schematic summary of the cascade of cellular reactions necessary to restore structure and function of CNS neurons following axonal disruption.

Bonhoeffer (1994); Aubert et al. (1995) and Yen and Kalb (1995)] (Fig. 2).

Damage to axons results first in the complete degeneration of the distal stump and partial degeneration or retraction of the proximal axons [Fig. 3(A)] that is followed by an initial regeneration response. The proximal cut ends form growth cones, that advance towards the lesion site. However, these terminal sprouts emitted by the lesioned axons are transient and never elongate for $>1 \mathrm{~mm}$ into the lesion area (Ramón y Cajal, 1928; Richardson et al., 1982; Borgens et al., 1986; Schnell and Schwab, 1993). These sprouts are later retracted and usually the proximal stump of the cut axon dies back. Exceptions of this 'dying-back' phenomenon are the persisting terminal sprouts of corticospinal axons (Bernstein and Bernstein, 1971; Li and Raisman, 1995) and of transected postcommissural fornix axons (Stichel and Müller, 1994a; Stichel et al., 1995b) [Fig. 3(B)]. The latter axons persist at the lesion site for at least up to 2 years after lesion. The spontaneous terminal sprouting has to be distinguished from another type of sprouting, the collateral sprouting [ $\mathrm{Li}$ et al. (1994); for review see Frotscher et al. (1997)]. Collateral sprouting refers to the growth of processes from an intact axon. While both types of sprouting may occur in parallel after a CNS lesion, most regrowing sprouts observed after CNS lesion are probably collateral sprouts of nonlesioned afferent projections to a partially denervated CNS region (Raisman and Field, 1973; McMahon and Kett-White, 1991; Rossi et al., 1991; Li et al., 1994; Schauwecker and McNeill, 1995). Interestingly collateral and terminal sprouting takes only place in regions with little or no myelin at all (Kapfhammer and Schwab, 1994; Stichel et al., 1995a,b).
Spontaneous terminal sprouting of damaged axons indicates the initial attempt and the potential of mature CNS neurons to regenerate. However, the axon sprouts stop growing after a short distance. While this lack of elongation might suggest an inherent switch into a growth arrest state, the most favored hypothesis suggests extrinsic growth-inhibitory factors in the immediate environment of the growth cone (see Section 3.2). The universality of the abortive axonal sprouting and the susceptibility of axonal elongation to extrinsic factors support the concept that sprouting and elongation are differentially regulated processes (Ramón y Cajal, 1928; Schnell et al., 1994). Schwab and coworkers (1994) have shown that sprouting of severed corticospinal axons is regulated by neurotrophic factors (NTFs), while elongation of the same axons is influenced by lesion-induced extrinsic determinants.

One major extrinsic constraint for regrowing axons is the scar within the lesion site (see Section 3.2). In most cases where axon regeneration was stimulated (see Section 5) the fibers grew around the
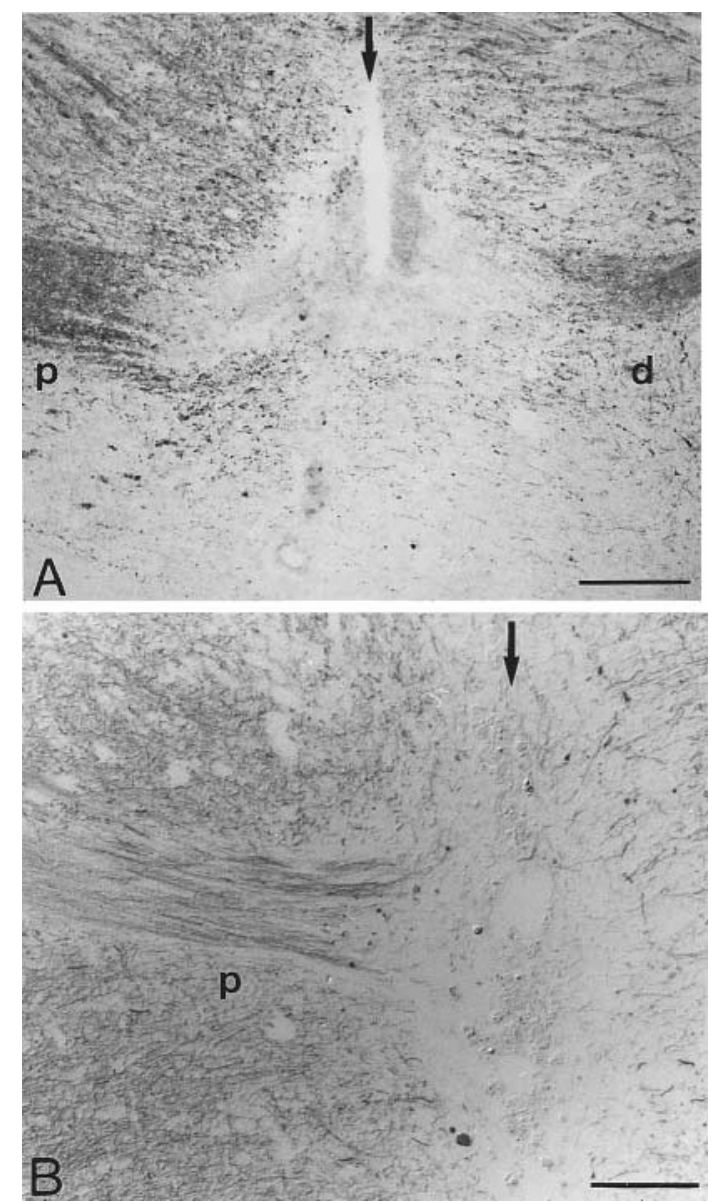

Fig. 3. Transected postcommissural fornix axons fail to regenerate. (A) Within 1 week after mechanical transection fornix axons degenerate up to $500 \mu \mathrm{m}$ in the antero- and retrograde direction (arrow, lesion site). (B) During the following week the axons spontaneously sprout up to the lesion site (arrow). They reach but fail to elongate across the lesion border. d, Distal; p, proximal. Scale bars $100 \mu \mathrm{m}$. 
lesion site rather than through the center. This implicates misrouting of axons with a high risk of inappropriate pathway choices and failure to innervate the normal target as well as possible troublesome interference with surrounding projections. Therefore, a crucial element of successful axonal regeneration is a continuous pathway through the former lesion site.

Once the axons have overcome the scar barrier, they encounter the problem of choosing the right pathway to their former target and the correct target neurons. Perhaps the clearest suggestion for these problems comes from studies of normal nervous system development. It was shown that process outgrowth depends on the molecular composition of the surrounding substrate. Growth cones encounter a variety of guidance molecules, attractive or repulsive, that are either short-range (immobilized) or long-range (diffusible) signals [for reviews see Dodd and Schuchardt (1995); Keynes and Cook (1995) and Goodman (1996)]. Interestingly, some of the immobilized molecules are re-expressed or constutively present along lesioned pathways. The enhanced expression of the guidance molecules TEN-C and proteoglycans along lesioned pathways has been reported (see Section 3.2) and the myelin growth inhibitors persist in unlesioned myelinated neuropil bordering the lesion site (see Section 3.2). Of par- ticular importance is the ECM molecule laminin, which promotes and directs the growth of processes extending from a broad range of neurons (Salonen et al., 1987; Kuffler and Luethi, 1993; Kuhn et al., 1995). Alternatively, it is accepted that growth cones can be steered by diffusible gradients of ions and transmitters (Kater et al., 1988; Kater and Lipton, 1995; Kuffler, 1996) and it is very likely that diffusible growth factors secreted from the denervated target can attract regrowing axons to appropriate locations (McFarlane and Holt, 1997). Recently, it was demonstrated that a spatially restricted distribution of nerve growth factor (NGF) in the hippocampal formation dictates what regions are reinnervated by sprouting axons (Hagg and Varon, 1993; Conner and Varon, 1994; Conner and Varon, 1995). Very similarly, in the spinal cord NGF promotes the reentry of sensory fibers into nonpermissive white matter (Oueda and Hagg, 1996). These studies suggest that NGF is tropic and may provide directional, target-dependent information to ensure appropriate axon guidance. ECM molecules and NGF might act in concert to guide axons along a given pathway. Such interactions should allow the use of a limited number of factors in a large number of combinations, each of which provides guidance specificity to different populations of axons.

Table 1. Experimental approaches to promote axonal regeneration in adult mammalian CNS

\begin{tabular}{|c|c|c|}
\hline Experimental approach & Methods & Region of treatment \\
\hline $\begin{array}{l}\text { Overexpression of neurite-growth } \\
\text { associated proteins }\end{array}$ & $\begin{array}{l}\text { In vivo gene transfer } \\
\text { Transgenic mice }\end{array}$ & Olfactory bulb, cortex, hippocampus \\
\hline Delivery of neurotrophic substances & $\begin{array}{l}\text { Intraventricular infusion } \\
\text { Polymer matrix } \\
\text { Transplanted genetically modified cells } \\
\text { In vivo gene transfer } \\
\text { Activation of intrinsic growth factors }\end{array}$ & $\begin{array}{l}\text { Striatum } \\
\text { Spinal cord, ventricle, subst. nigra } \\
\text { Sympathetic ganglia }\end{array}$ \\
\hline \multicolumn{3}{|l|}{ Implantation of growth-promoting cells } \\
\hline Fetal CNS tissue & $\begin{array}{l}\text { Tissue blocks } \\
\text { Suspension graft }\end{array}$ & $\begin{array}{l}\text { Spinal cord } \\
\text { Spinal cord, hippocampus }\end{array}$ \\
\hline Schwann cells & $\begin{array}{l}\text { Peripheral nerve graft } \\
\text { Coupled to prostheses/matrices } \\
\text { Suspension graft }\end{array}$ & $\begin{array}{l}\text { Spinal cord, optic nerve, dorsal root } \\
\text { Spinal cord, optic nerve } \\
\text { Spinal cord, thalamus, ventricle, fornix }\end{array}$ \\
\hline Astroblasts & $\begin{array}{l}\text { Coupled to prostheses/matrices } \\
\text { Suspension graft }\end{array}$ & $\begin{array}{l}\text { Spinal cord, corp. callosum, dorsal root } \\
\text { Optic nerve, cortex, fornix }\end{array}$ \\
\hline Olfactory bulb ensheathing cells & $\begin{array}{l}\text { Coupled to prostheses/matrices } \\
\text { Suspension graft }\end{array}$ & $\begin{array}{l}\text { Dorsal root, fimbria fornix } \\
\text { Spinal cord }\end{array}$ \\
\hline Microglial cells & Suspension graft & Spinal cord \\
\hline Neutralization of neurite growth & Antibodies against NI35/250 & Spinal cord, optic nerve, fimbria fornix \\
\hline & Transglutaminase & Optic nerve \\
\hline Reduction of scarring & $\begin{array}{l}\text { Piromen } \\
\text { Excision of scar } \\
\text { Trypsin, elastase, collagenase } \\
\text { X-irradiation } \\
\text { Glucocorticoids } \\
\text { Antibodies against TGF } \beta \\
\text { Antibodies against collagen IV } \\
\text { Prolylhydroxylase inhibitor }\end{array}$ & $\begin{array}{l}\text { Spinal cord } \\
\text { Spinal cord } \\
\text { Spinal cord } \\
\text { Spinal cord } \\
\text { Spinal cord, cortex } \\
\text { Cortex } \\
\text { Fornix } \\
\text { Fornix }\end{array}$ \\
\hline Electric field & Direct current field & Spinal cord \\
\hline
\end{tabular}


Within the target 'stop- or docking-signals' are necessary to arrest the homecoming axons at the appropriate target neurons. A well-studied example of such a docking mechanism is the retinotectal projection, in which molecules that specify the anteriorposterior tectal axis for fibers of the temporal retina are reexpressed upon denervation in the adult superior colliculus (Holt and Harris, 1993; Wizenmann et al., 1993). These molecules, ELF-1 (ephrin-A2) and RAGS (ephrin-A5, AL-1), are ligands for Eph-related receptor tyrosine kinases and are repellent for temporal or temporal and nasal retinal axons, respectively (Nakamoto et al., 1996; Monschau et al., 1997). The elongation of ganglion cell axons is determined by a concentration gradient of ELF-1 and the retinal fibers stop when facing a critical change in the gradient that is $5 \%$ or more across the diameter of the growth cone (Baier and Bonhoeffer, 1992). Neurotransmitters and $\mathrm{N}$ methyl-D-aspartate (NMDA) receptors are other classes of molecules that comprise stop signals for axon growth and thereby may contribute to target cell selection (Kater and Mills, 1991; Baird et al., 1996).

In the final stage regrowing axons must regain synaptic contact with the target neurons and normal functional properties, for example, conduction velocity and action potential amplitude. The latter parameters are determined by the diameter and the course of the axon and the presence of a myelin sheath.

A cascade of molecular and cellular reactions is necessary to restore structure and function of lesioned CNS projections. The striking similarity of these steps to developmental events indicates that the understanding of the cellular and molecular biology of development holds the key to restoration of CNS projections after lesion.

\section{EXPERIMENTAL APPROACHES TO PROMOTE AXONAL REGENERATION}

The rapid progress of molecular and biochemical techniques and the knowledge of the mechanisms underlying neurodegeneration and regeneration encouraged several attempts to manipulate the regrowth response of lesioned neurons. These efforts concentrate on two main strategies:

1. the activation of intrinsic neuronal capacities by overexpression of regeneration-promoting genes (see Section 5.1) or by the delivery of neurotrophic substances in the vicinity of lesioned axons or perikarya of injured neurons (see Section 5.2); and

2. the modification of the nonpermissive environment in the lesioned CNS tissue by the implantation of acellular guiding prostheses (see Section 5.3.1), fetal neural tissue (Section 5.3.2) and glial cells (see Sections 5.3.3, 5.3.4, 5.3.5 and 5.3.6) or the neutralization of growth inhibitory molecules (see Section 5.4) and the permeabilization of the lesion scar (see Section 5.5), respectively.

An additional strategy is the application of an electrical field across lesion sites (see Section 5.7).
Table 1 provides an overview of the different experimental approaches to stimulate axon regeneration following CNS lesioning.

\subsection{Overexpression of Neurite-Growth Associated Proteins}

Several lines of evidence have indicated that GAP-43, Bcl-2 and c-Jun play important roles in determining the inherent growth properties of CNS neurons (see Section 3.1). However, only certain populations of neurons continue to express constitutively high levels of these genes. Interestingly, these neurons have been associated with a high degree of plasticity [for review see Benowitz and Routtenberg (1997) and Herdegen et al. (1997)]. Transgenic mice provide additional compelling evidence for the central role of such genes in axon regeneration (Aigner et al., 1995; Chen et al., 1997). Upregulation of their expression in affected neurons might be a useful approach to promote axonal regeneration. In this respect, an efficient potential therapy is on the way to be established using gene transfer methods. A first attempt to direct overexpression of GAP-43 in vivo was performed by Verhaagen and coworkers (Holtmaat et al., 1996; Hermens et al., 1997). Adenoviral vector-mediated GAP-43 expression induced alterations of membrane organization in olfactory axon terminals (Holtmaat et al., 1997), which underline the influence of this protein on morphological plasticity of neurons.

Gene therapy directed to enhance expression of growth-associated proteins in the CNS could provide a new strategy for treatment of traumatic injury.

\subsection{Delivery of Neurotrophic Substances}

Neurotrophic factors are molecules that, by definition, are capable of supporting the survival, growth and differentiation of neurons and of regulating synaptic plasticity during development and in the mature nervous system. In nervous tissue NTFs are available only in limited quantities and induce cellular changes over hours to days through signaling pathways that induce gene transcription and protein synthesis. The list of identified NTFs is large and there is considerable more complexity and diversity than initially anticipated (Table 2). NGF was the first NTF discovered (Levi-Montalcini, 1987) and is often viewed as the prototype for all NTFs. Other members of the neurotrophin family are the brain-derived neurotrophic factor (BDNF) neurotrophin-3 (NT-3) and neurotrophin-4/5 (NT-4/ 5) (Bothwell, 1995; Lewin and Barde, 1996). Besides this NGF family several NTFs belonging to different protein families were identified, such as the FGF, the platelet-derived growth factor (PDGF), the transforming growth factor (TGF) and the insulin-like growth factor (IGF) families. NTFs are target-derived molecules, while autocrine and nontarget-derived paracrine modes of presentation have also been described. They are synthesized by astrocytes, oligodendrocytes and neurons [for review see Müller et al. (1996)] and may act on both neurons and glial cells. Interestingly, individual popu- 
Table 2. Partial list of neurotrophic factors and their neuronal specificities in CNS

\begin{tabular}{|c|c|c|}
\hline Name & Responsive CNS neurons & References \\
\hline NGF & $\begin{array}{l}\text { Basal forebrain cholinergic neurons } \\
\text { Striatal cholinergic neurons }\end{array}$ & $\begin{array}{l}\text { Hefti (1986); } \\
\text { Holtzman et al. (1995) }\end{array}$ \\
\hline BDNF & $\begin{array}{l}\text { Spinal motor neurons } \\
\text { Cortical motor neurons } \\
\text { Basal forebrain cholinergic neurons } \\
\text { Basal forebrain GABAergic neurons } \\
\text { Mesencephalic GABAergic neurons } \\
\text { Nigral dopaminergic neurons } \\
\text { Cerebellar granular neurons } \\
\text { Hippocampal neurons } \\
\text { Retinal ganglion neurons }\end{array}$ & $\begin{array}{l}\text { Sendtner et al. (1992); Yan et al. (1997) } \\
\text { Yan et al. (1997) } \\
\text { Alderson et al. (1990); Hyman et al. (1991) } \\
\text { Koliatsos et al. (1994) } \\
\text { Hyman et al. (1994) } \\
\text { Hyman et al. (1991); Hyman et al. (1994) } \\
\text { Nonomura et al. (1996); Coffey et al. (1997) } \\
\text { Zafra et al. (1991); Patterson et al. (1992) } \\
\text { Barde (1990); Sawai et al. (1996) }\end{array}$ \\
\hline NT-3 & $\begin{array}{l}\text { Spinal motor neurons } \\
\text { Cortical motor neurons } \\
\text { Mesencephalic GABAergic neurons } \\
\text { Nigral dopaminergic neurons } \\
\text { Hippocampal neurons } \\
\text { Locus coeruleus neurons } \\
\text { Cerebellar granule cells }\end{array}$ & $\begin{array}{l}\text { Maisonpierre et al. (1990) } \\
\text { Zhou and Rush (1994); Grill et al. (1997) } \\
\text { Hyman et al. (1994) } \\
\text { Hyman et al. (1994) } \\
\text { Zafra et al. (1991); Patterson et al. (1992) } \\
\text { Senut et al. (1995) } \\
\text { Nonomura et al. (1996) }\end{array}$ \\
\hline NT-4/5 & $\begin{array}{l}\text { Cortical motor neurons } \\
\text { Basal forebrain cholinergic neurons } \\
\text { Mesencephalic GABAergic neurons } \\
\text { Nigral dopaminergic neurons } \\
\text { Cerebellar granular cells } \\
\text { Hippocampal neurons } \\
\text { Striatal neurons } \\
\text { Locus coeruleus neurons } \\
\text { Retinal ganglion neurons }\end{array}$ & $\begin{array}{l}\text { Junger and Varon (1997); Sendtner et al. (1996) } \\
\text { Koliatsos et al. (1994); Alderson et al. (1996) } \\
\text { Hyman et al. (1994) } \\
\text { Hyman et al. (1994) } \\
\text { Huber and Chao (1995) } \\
\text { Ip et al. (1993a); Lessmann et al. (1994) } \\
\text { Hynes et al. (1994) } \\
\text { Friedman et al. (1993) } \\
\text { Cohen et al. (1994); Sawai et al. (1996) }\end{array}$ \\
\hline FGF & $\begin{array}{l}\text { Cortical motor neurons } \\
\text { Spinal cord neurons } \\
\text { Hippocampal neurons } \\
\text { Thalamic neurons } \\
\text { Septal neurons } \\
\text { Retinal ganglion neurons }\end{array}$ & $\begin{array}{l}\text { Grothe and Wewetzer (1996) } \\
\text { Gouin et al. (1996) } \\
\text { Ferhat et al. (1997) } \\
\text { Ferguson and Johnson (1991) } \\
\text { Lindholm et al. (1994) } \\
\text { Lipton et al. (1988); Bähr et al. (1989) }\end{array}$ \\
\hline
\end{tabular}

lations of neurons may respond to a variety of NTFs and, conversely, a single factor may act on several distinct neuronal populations.

Besides their potent effects on the survival of neurons, in vitro studies also demonstrate an important role of NTFs in stimulating axon regrowth and branching (Lindsay, 1988; Cohen et al., 1994; Ahmed et al., 1995). With these pronounced effects on neurite outgrowth in mind it seems reasonable to ask whether the absence of trophic factors may lead to regeneration failure and whether the postlesion application of NTFs may promote axon regrowth. Recently, studies analysing the effects of postlesion applied NTF on morphological and functional recovery of lesioned CNS projections have been initiated. These studies indicate that BDNF and NT$4 / 5$ promote the regrowth of injured retinal ganglion cell axons (Mansour-Robaey et al., 1994; Sawai et al., 1996), NT-3 stimulates sprouting of corticospinal projections (Schnell et al., 1994; Grill et al., 1997), BDNF and NT-3 infusion enhances axonal regeneration of propriospinal and brain stem axons (Xu et al., 1995a) and sensory as well as motor and brain stem axons grow toward a source of NGF in lesioned spinal cord (Tuszynski et al., 1996).

The existence of a blood-brain barrier that blocks the entry of systemically circulating proteins into the nervous system and the need for high concentrations of these substances have required invasive techniques as the main method for NTF delivery. In experimental animals, NTFs have been injected intraventricularly through chronically implanted cannulas with/without the help of osmotic minipumps. Despite unknown degradation kinetics of the neurotrophic substances in the cerebrospinal fluid and the brain parenchyma and the short biological half-life of some of the neurotrophins, infused NTFs have been shown to exert beneficial effects on axon regeneration. However, since NTFs rarely influence only a single neuronal target population the broad delivery of NTFs via the intraventricular application may result in side-effects on multiple nontargeted cells. For example, intracerebroventricular infusions of NGF not only protect cholinergic neurons from degeneration but also induce sprouting of sympathetic neurites that invest cerebral blood vessels (Saffran et al., 1989), cause weight loss (Williams, 1991), and promote sprouting of spinal cord sensory neurites (Tuszynski et al., 1994). These diverse NGF effects, a consequence of the broad delivery of NGF after infusion into the ventricular system of the brain, could limit clinical application. Another drawback using NTFs to promote axonal regeneration is their limited tissue pen- 
etration (Lapchak et al., 1993; Emmett et al., 1996). Thus direct application of NTFs to the lesion site and maintenance of elevated trophin levels over several weeks seems to be required and make repeated injections or refilling of pump reservoirs necessary. Ideally, neurotrophin delivery into the nervous system should be target-specific, regionally restricted, well-tolerated and of sufficient concentration to elicit a response.

Alternatives to NTF infusion have been developed such as slow releasing intracerebral implants that contain the active protein embedded in a biodegradable polymer matrix (Powell et al., 1990) and genetically modified cells that secrete the desired NTF [for reviews see Doering (1996); Verhaagen et al. (1996) and Snyder and Senut (1997)]. The most often used technique for gene transfer is the ex vivo approach, wherein genetically modified cultured cells are transplanted into the CNS. Numerous studies have employed fibroblasts and viral vectors for the in vitro gene transfer of NTFs (Rosenberg et al., 1988; Lucidi-Phillipi et al., 1995; Ray et al., 1995; Senut et al., 1995; Grill et al., 1997). However, one major obstacle that arises using this approach is the continued growth of fibroblasts after implantation leading to varying degrees of tumor formation (Hoffman et al., 1993; Tuszynski et al., 1994). Polymer encapsulation may help to overcome this problem since it prevents the inherent risk of tumor formation and protects the genetically modified cells from immune destruction, while permitting the diffusion of molecules into the surrounding tissue for $>1$ year after implantation in adult rat ventricles (Emerich et al., 1994; Winn et al., 1996). Recently, X-ray treated genetically modified Schwannoma cells stimulated axonal regeneration in the nigrostriatal pathway (Brecknell et al., 1996), genetically modified rat astrocytes have been shown to survive well after transplantation and express the desired protein (Lundberg et al., 1996) human astrocytes have been efficiently infected with a retrovirus harbouring the NGF gene (Lin et al., 1997) and rat Schwann cells genetically modified to secrete BDNF increased axonal regeneration in spinal cord (Menei et al., 1998). The latter cell type may be a useful gene carriers, as astrocytes are natural hosts of the CNS and can be expanded in vitro. Another strategy to express NTF in lesioned CNS areas is the in vivo viral vector-mediated gene transfer. Numerous vectors have been shown to be effective for gene transfer in the CNS, including those derived from herpes viruses, adenoviruses, adenoassociated viruses and human immunodeficiency viruses (Le Gal La Salle et al., 1993; Kaplitt et al., 1994; Naldini et al., 1996). Viral vectors carrying neurotrophin genes have been successfully used to locally express neurotrophic molecules in the lesioned nervous system (Fedoroff et al., 1992; Geschwind et al., 1994; Wang et al., 1995b). However, the injected viruses have been shown to exert immune responses indicating the cytotoxicity of the current viral generations (Byrnes et al., 1995; Hodgson, 1995). This risk and the occurrence of replication competent viral particles in viral vector stocks are severe problems that need to be resolved before the great potential of these viruses for neurotrophic strategies may be used in neuroregeneration studies.

Another feasible approach to influence neurotrophic actions may be the stimulation of synthesis, release and activity of endogeneous growth factors. It is known that hormones, corticosteroids, thyroid hormone and retinoic acid are involved in the regulation of NTF synthesis (Hefti et al., 1986; Haskell et al., 1987; Lindholm et al., 1990) and thereby may provide tools for the pharmacological manipulation of NTF expression. Thus, the alkaloid-like compounds K-252a and K-252b, directly and selectively inhibit the neurotrophin receptors and at lower concentrations, selectively potentiate the actions of NT3 (Koizumi et al., 1988; Knusel and Hefti, 1991), suggesting that it may be possible to develop highly selective neurotrophin agonists and antagonists. Moreover, glucocorticoids (Chao and McEwen, 1994; Kononen et al., 1994; Schaaf et al., 1997), the ganglioside GM1 (Rabin and Mocchetti, 1995; Ferrari and Greene, 1996) and the glutamate antagonists MK-801 and NBQX (Lindvall et al., 1992; Rocamora et al., 1994; Timmusk and Metsis, 1994) mimic and potentiate many activities of NTFs including stimulation of neurite outgrowth in vitro as well as in vivo.

\subsection{Grafting}

One of the most intriguing possibilities for promoting the regeneration of damaged CNS is through the implantation of growth supportive material in the immediate environment of the lesioned neurons. Historically this strategy is one of the earliest attempts to induce repair of the CNS and has become widely used in the regeneration field. Depending on the material that is grafted different aspects of the regeneration process are addressed. Using fetal CNS tissue, transplantation may be primarily a useful tool to replace lost cells in a lesioned area. On the other hand, the latter as well as acellular prostheses and glial implants may be viewed as modifiers of the lesion area, which either interfere with the process of scar formation by physically preventing the infiltration of cellular elements that promote the development of a glial scar (Reier and Houle, 1988) resulting in looser scarring and/or provide a bridge across the impermeable lesion scar by reestablishment of a growth supportive framework (Li and Raisman, 1997). Finally, cellular implants may be used as a source for trophic factors for axonal growth.

\subsubsection{Acellular Bridges}

In the intensive search for methods to improve the regenerative capabilities of CNS tissues, many different artificial bridging models have been attempted. All of these approaches aim to provide:

1. oriented paths of low physical resistance which guide the regrowing axons through the dense glial-connective tissue scar; and

2. support frames for glial and vascular reorganization in lesioned CNS tissue.

In this respect, various matrices have been used, like collagen, hydrogels, nitrocellulose membranes, car- 
bon filaments, glass filaments, gelfoam and guidance tubes of different polymers (Gelderd, 1990; Marchand and Woerly, 1990; Khan et al., 1991; Schnell and Schwab, 1993; Joosten et al., 1995; Montgomery et al., 1996; Borgens and Bohnert, 1997), with varying but generally unsatisfactory, degrees of success. In some of these conduits limited axon growth was reported, but these axons never succeeded in reentering into the host CNS tissue. Addition of neuroactive substances like laminin to a collagen matrix bridge, however, enhanced the axonal ingrowth but allowed only single axons to cross the bridge and to enter the distal spinal cord stump (Goldsmith and de la Torre, 1992). Although the artificial bridges may provide a favorable milieu for axons and a new avenue to modulate scar formation, in most cases the axonal regrowth into the former pathway is halted by properties of the distal graft-host interface and structural repair of a lesioned projection is never achieved.

On the other hand, numerous studies have confirmed the usefulness of these matrices when used as vehicles for growth-promoting glial cells (Kliot et al., 1990; Lustgarten et al., 1991; Paino and Bunge, 1991; Plant et al., 1995; Xu et al., 1995b) and for growth factor application (Powell et al., 1990; Houle and Ziegler, 1994; Wells et al., 1997). The advantages of such a matrix/glial cell or matrix/NTF combination are the fixation and accumulation of cells in the implantation site, the provision of a defined environment and the controlled and slow release of neuroactive substances (Powell et al., 1990).

\subsubsection{Fetal CNS Tissue}

One of the most intriguing possibilities for promoting the reconstitution of damaged CNS parts is through the implantation of fetal tissue grafts. Many experiments in the past several years have shown that transplantation of fetal CNS tissue can serve as an important approach in studies of CNS regeneration. One of the exciting findings to emerge from this field is that there are essentially two main avenues through which fetal grafts can achieve their beneficial effects.

First, regenerative potential can be improved by replacing damaged or lost adult neurons with fetal ones. Transplants of developing CNS tissue have revealed a remarkable capacity to develop in the new environment, to integrate with the host, to form synapses on host cells and to receive synapses from host neurons [Isacson et al. (1995); Pundt et al. (1996); for reviews see Barker et al. (1993); Brundin and Wictorin (1993) and Isacson and Deacon (1997)]. This technique has now been used in experimental clinical trials in many patients with neurodegenerative diseases and the results are promising [for reviews see Sladek and Shoulson (1988); Freed (1991); Lindvall (1991); Kupsch et al. (1995); Olanow et al. (1996) and Wichmann et al. (1996)].

Second, and even more important for axonal regeneration, fetal grafts may serve as a tissue bridge or a relay station that could facilitate axonal elongation across a lesion site. Moreover, fetal transplants may be viewed as a modifier of the scar matrix and since such grafts also introduce imma- ture glial cells, they are also a source of trophic and tropic factors for axonal growth (Bregman and Reier, 1986). These potential beneficial effects for regenerating systems have been illustrated by intraspinal grafting studies. In neonatal rats Bregman and colleagues have observed that fetal spinal cord can be used in the injured spinal cords as a bridge for axons that are either in their normal developmental growth phase or are undergoing actual regrowth. More recently, the enhanced ability of embryonic neurons to grow and reach distant targets has been used experimentally to show that both ends of a foetal spinal cord graft will connect and restore function across a complete spinal cord lesion (Iwashita et al., 1994). On the other hand, no evidence has yet emerged for fetal grafts serving as bridges in adult spinal cord [for reviews see Horvat (1992) and Schwab and Bartholdi (1996)]. Thus far the only transplantation study in adult mammals is that of Kromer et al. (1981), who showed that transplants of fetal hippocampus serve as bridges that facilitate the regrowth of septal cholinergic fibers and their reinnervation of the host hippocampus.

\subsubsection{Peripheral Nerve/Schwann Cells}

Tello performed one of the earliest recorded PNS to CNS implantation experiments (Tello, 1911). He implanted predegenerated grafts of sciatic nerve into the mammalian cerebrum and after $c a 2$ weeks, he noted extensive growth of central fibers into the graft. Following this initial trial a number of studies have confirmed that PNS grafts constitute a sufficient stimulus for axonal regeneration and that fully mature CNS axons have the capacity to regenerate (Richardson et al., 1982; Thanos and Vanselow, 1989; Houle, 1991; Thanos, 1992; Carter and Jhaveri, 1997; Thanos et al., 1997; Watanabe and Fukuda, 1997). Of particular relevance here are the studies of Aguayo and his colleagues. In a series of very elegant experiments, they showed that a proportion of lesioned adult mammalian retinal axons that regenerated into $\mathrm{PN}$ autografts for at least $2 \mathrm{~cm}$ grew out from the distal end of the implants and formed long-lasting, functionally effective synapses with tectal neurons (David and Aguayo, 1981; So and Aguayo, 1985; Vidal-Sanz et al., 1987; Keirstead et al., 1989; Bray et al., 1992; Carter et al., 1994). Recently, a revival of this technique with more refined surgical procedures was applied in the spinal cord. The elegant and technically difficult study of Cheng et al. (1996) demonstrated for the first time functional regeneration in the completely transected spinal cord by using several PNs stabilized by FGF-impregnated fibrin glue to bridge individual spinal axon bundles to the gray matter of the distal stump. This study is an important step towards the goal of efficiently restoring axonal regeneration in the damaged CNS. While in the above mentioned studies the PN grafts were placed directly into the lesion site, for example, in close proximity to the degenerating axon segments, in a recent study the effect of a PN graft placed in the vicinity of severed cell somata was analyzed. Berry et al. (1996a) showed that PN tissue introduced into the vitreous body promotes the regeneration of crushed optic 
nerve axons without the prerequisite for the suppression of growth inhibitory molecules. However, the PN-implantation studies also showed a number of limitations to this approach. Apart from the inevitable mechanical damage caused by the physical insertion of the nerves, the most favorable grafts pick up only a proportion of the host fibers (Cheng et al., 1996), the axons leaving the grafts show only restricted penetration of the central target tissues (Vidal-Sanz et al., 1987; Cheng et al., 1996) and in some cases abnormal connections may be formed (Zwimpfer et al., 1992).

There is evidence that the growth-promoting effects of transplanted PNs is dependent on the presence of viable Schwann cells in the nerve (Friede and Samorajski, 1968). Schwann cells express and secrete a variety of NTFs (Bandtlow et al., 1987; Acheson et al., 1991; Rende et al., 1992), ECM molecules (Bunge, 1993) and surface adhesion molecules (Bandtlow et al., 1990; Schachner, 1990; Martini, 1994) that stimulate axonal growth. Moreover, their abilities to organize into PN-like aligned arrays (Montgomery and Robson, 1993) and to modify the lesion-induced, dense astrocytosis ( $\mathrm{Li}$ and Raisman, 1997) may promote axonal regeneration. In fact, Schwann cell-free PN grafts fail to support CNS regeneration (Berry et al., 1988; Smith and Stevenson, 1988) as do Schwann cell-free collagen membranes (Kromer and Cornbrooks, 1985; Paino et al., 1994). A number of implantation studies have demonstrated that Schwann cells represent a very suitable and effective substrate for stimulating axonal regeneration (Chen et al., 1991; Martin et al., 1991; Montero-Menei et al., 1992; Neuberger et al., 1992; Montgomery and Robson, 1993; Raisman et al., 1993; Brook et al., 1994; Paino et al., 1994; Harvey et al., 1995; Plant et al., 1995; Xu et al., 1995b; Chen et al., 1996). Besides their growth-promoting effects, Schwann cells are also able to myelinate CNS axons (Blakemore, 1977) and thus have the capacity to myelinate regenerated axons (Chen et al., 1991; Felts and Smith, 1992; Guénard et al., 1993; Paino et al., 1994; Honmou et al., 1996; Li and Raisman, 1997). Different approaches have been used to introduce the Schwann cells into lesioned CNS. Initial attempts used tubes made of permeable gels (Levy et al., 1988; Cohen et al., 1990), synthetic polymers (Montgomery and Robson, 1993; Harvey et al., 1994; Xu et al., 1995b) or basement membrane components (Neuberger et al., 1992; Paino et al., 1994). Besides the fact that such prostheses are needed in cases in which a wide gap needs to be bridged (Guénard et al., 1991; Harvey et al., 1991) or the geometry of the proximal and distal stumps is complex (Shine et al., 1985; Aebischer et al., 1988), their use raises fundamental difficulties. Such solid large grafts themselves cause extensive damage to the host tissue and their size and the need for exact positioning restrict their application to more superficial lesion areas. In an attempt to minimize these complications a microtransplantation method for the controlled injection of cell suspensions has been developed (Schmidt et al., 1981; Emmett et al., 1990). Using this approach several studies have been successful in transplanting highly purified Schwann cell suspensions into the adult rat brain (Montero-
Menei et al., 1992; Brook et al., 1993; Brook et al., 1994; Li and Raisman, 1994; Pizzorusso et al., 1994; Fagiolini et al., 1997; Li and Raisman, 1997).

In our own work we have used this minimal invasive microtransplantation approach to introduce a Schwann cell suspension into the transected postcommissural fornix of the adult rat (Stichel et al. 1996) (Fig. 4). We could show that the injected Schwann cells, which are primary cells [Fig. 4(A)], do not form tumors upon grafting as some cell lines do (Tuszynski et al., 1994), migrate freely for considerable distances [Fig. 4(B)] and become integrated in neuropil or white matter, where they survived for at least 8 months after injection. The microimplanted Schwann cells did not prevent axonal degeneration of transected fornix fibers but promoted structural recovery of the projection. The regrowing fibers traversed the formerly impermeable lesion site and extended along their former pathway up to the normal target [Fig. 4(C and D)], where they reformed synaptic contacts (Stichel et al., 1997). In contrast to previous studies (see above), the postcommissural fornix fibers were remyelinated by central myelin. This impressive restoration of a lesioned fiber tract in rats as well as recent reports of functional recovery of visually deprived animals in the presence of implanted Schwann cells (Fagiolini et al., 1997) provide an encouraging argument for pursuing this approach to an appropriate therapeutical strategy. Further exciting data in favor of this approach are studies in our lab showing that even xenogeneic Schwann cells represent a source of nonimmunogenic graft material (Hermanns et al., 1997), while others demonstrated that large populations of Schwann cells can be expanded from adult human PN (Morrissey et al., 1995; Rutkowski et al., 1995; Van den Berg et al., 1995; Casella et al., 1996; Hanemann et al., 1997) and these human Schwann cells are also able to promote axonal regeneration (Levi et al., 1994; Guest et al., 1997). However, the task set to those working in that field is to analyze whether 'peripheralizing' the CNS induces changes in the physiological properties of the host tissue.

\subsubsection{Astroblasts}

In an attempt to avoid potential drawbacks by implanting foreign cells to the CNS and to promote axonal regrowth, several studies have explored the effects of another cellular transplant with growthpromoting capacities, the astrocytes. From studies of Smith and coworkers (Smith et al., 1986, 1990; Smith and Miller, 1991; Smith and Silver, 1996) it becomes apparent that age and differentiation stage of astrocytes play an important role in their capacity to promote regeneration. Thus, in contrast to their mature counterparts immature astrocytes, called astroblasts, have been shown to exert multiple beneficial effects on the regeneration process. Astroblasts, implanted before the age of postnatal day 14 , produce high concentrations of neurotrophic and neurite outgrowth promoting factors (NietoSampedro et al., 1982; Martin, 1992), suppress scar formation (Smith et al., 1986; Wang et al., 1995a; Smith and Silver, 1996), are highly plastic and motile (Goldberg and Bernstein, 1988; Bernstein 

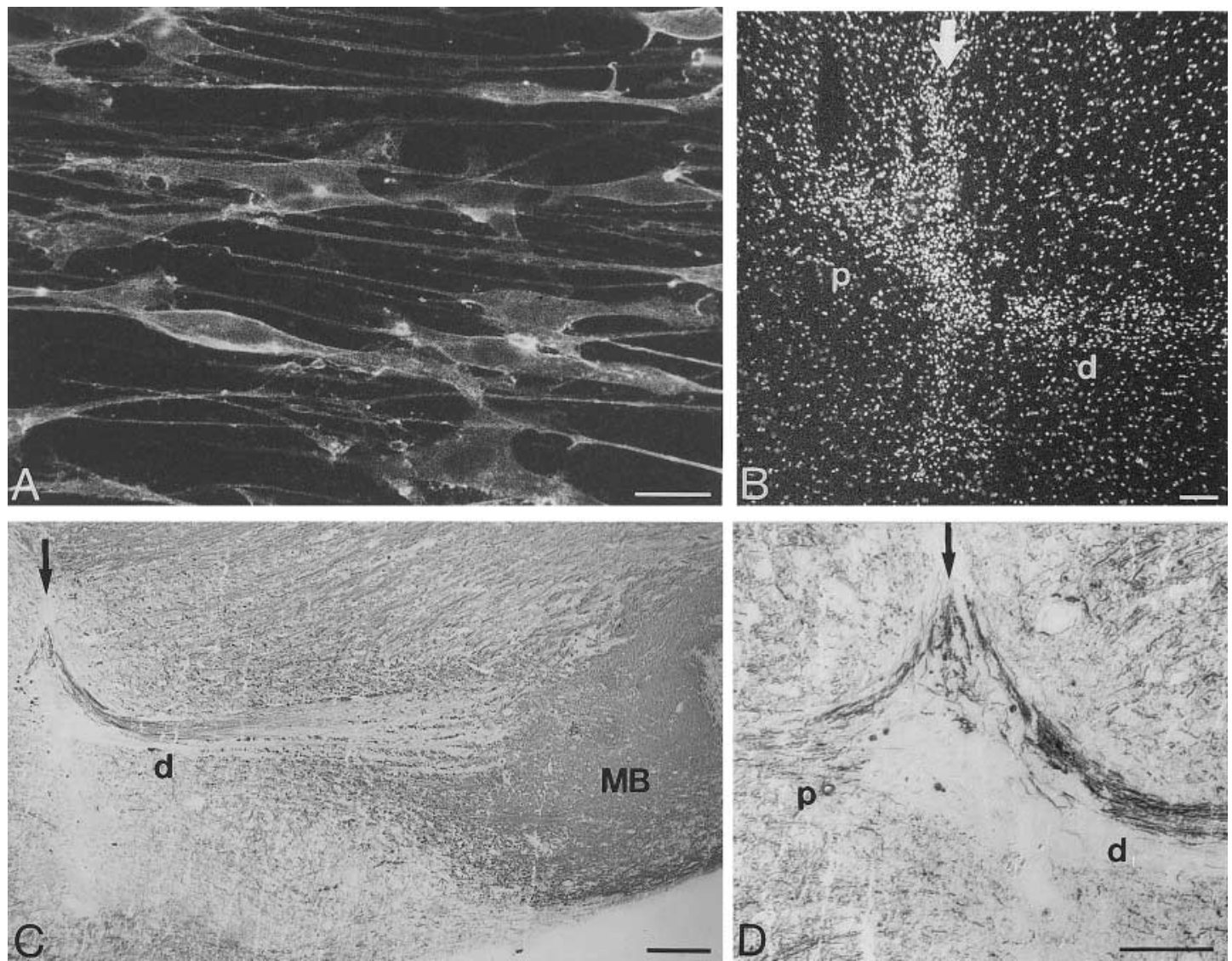

Fig. 4. Regeneration of transected postcommissural fornix after microinjection of a Schwann cell suspension into the lesion site. (A) Cultured Schwann cells exhibiting immunoreactivity for low affinity NGF receptor. (B) Distribution of prelabeled (Hoechst dye) Schwann cells microinjected into the transected postcommissural fornix. A characteristic gradient of Schwann cells is formed in a pattern radiating from the injection site. (C) At 6 weeks after transection and Schwann cell injection lesioned fornix fibers cross the former lesion and injection site and elongate within their normal pathway up to their target, the mammillary body (MB). (D) High-magnification photomicrograph shows the fibers overriding the former lesion and injection site. Arrows indicate the location of lesion/injection site. d; Distal, p; proximal. Scale bars $10 \mu \mathrm{m}$ (A), $100 \mu \mathrm{m}(\mathrm{B}-\mathrm{D})$.

and Goldberg, 1989, 1991; Smith and Miller, 1991; Smith and Silver, 1996) and express a distinct form of protease (Kalderon et al., 1990a). Importantly, cultured astroblasts, introduced into lesion sites either as part of embryonic tissue, coupled to prosthesis and gel matrix vehicles or as a pure cell suspension, promote the regrowth of certain axons across the corpus callosum midline (Smith et al., 1986; Smith and Silver, 1996), enhance regrowth of axons across lesions in the corticospinal tract (Schreyer and Jones, 1987) and promote regeneration of dorsal root fibers (Kliot et al., 1990) and of optic nerve fibers (Sievers et al., 1995).

We assessed the influence of microimplanted cultured astroblasts on the growth behavior of lesioned axons in our lesion model the transected postcommissural fornix (Wunderlich et al., 1994) (Fig. 5). In contrast to implanted Schwann cell suspensions [Fig. 4(B)], microinjected astroblasts formed an eliptical, well-integrated bolus of nonmigrating cells [Fig. 5(B)]. However, similar to the Schwann cell effects, they did neither prevent nor change the spatiotemporal pattern of degeneration in the proxi- mal and distal fornix stumps, but increased the number of spontaneously sprouting axons of transected fornix. Quantitative analysis revealed a significant increase in myelinated axons of up to $40 \%$ compared to animals without implant. Regrowing axons neither entered nor bypassed the astrocytic implant, but grew along its surface and failed to elongate into the distal stump [Fig. 5(C)]. Thus, structural regeneration of the tract was prevented by the inability of regrowing fibers to cross the lesion/ implantation site. While our studies confirmed the growth stimulating effects of implanted astroblasts, they argue against a scar reducing effect of astroblasts and underline the key role of the lesion scar in regeneration failure of adult mammalian CNS.

In considering using astroblasts to promote axonal regeneration in traumatic CNS lesions, the requirement for embryonic primary cells is a serious ethical and technical problem. Continuous cell lines have been proposed as an alternative to fetal tissue. Therefore, a panel of astrocyte cell lines with growth-permissive or nonpermissive properties were recently established, using retrovirus-mediated trans- 

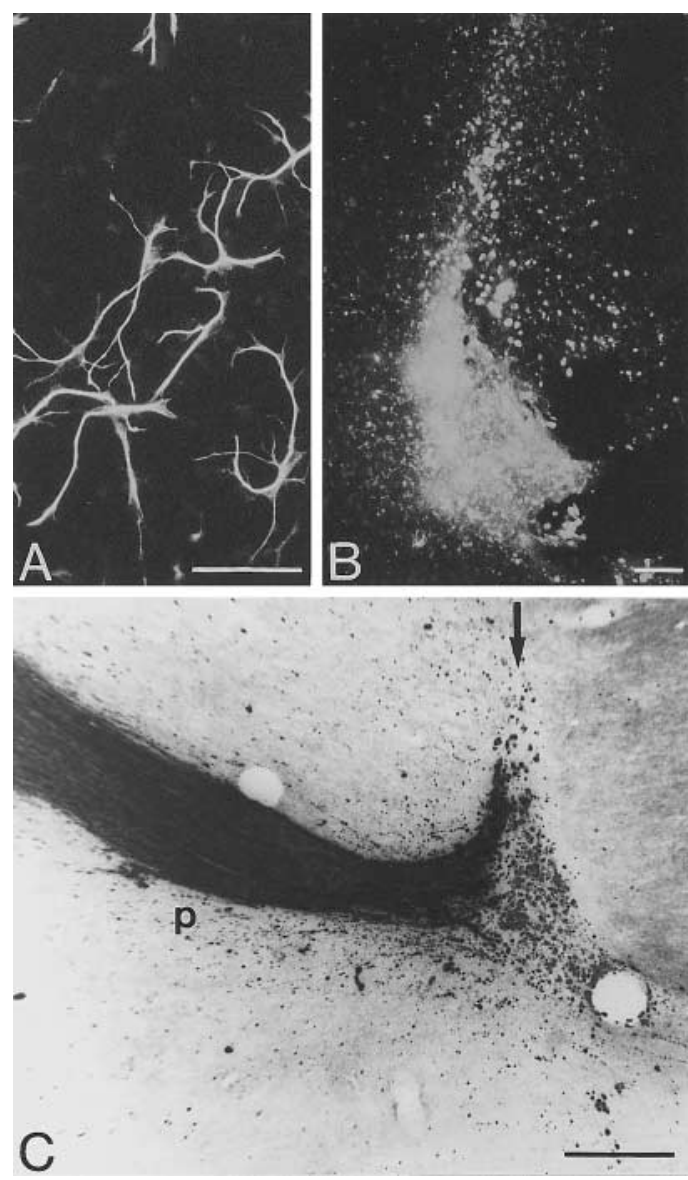

Fig. 5. Influence of microinjected astroblasts on axonal regeneration in transected postcommissural fornix. (A) Cultured immature astrocytes were prelabeled with fluorescent Dye I and (B) microinjected into the lesion site immediately after transection of the tract. (C) Anterogradely HRP-WGA labeling of the tract revealed that in animals with astroblast implant: (i) the number of spontaneously sprouting axons significantly increases; but (ii) the axons fail to enter or grow around the implant. Scale bars $50 \mu \mathrm{m}$ (A), $100 \mu \mathrm{m}$ (B and C).

fer of the gene for SV40 large T antigen (Isono et al., 1992; Groves et al., 1993; Fok-Seang et al., 1995). These cell lines express several proteins characteristic for astrocytes like fibronectin, laminin, $\mathrm{N}-\mathrm{CAM}, \mathrm{TEN}$ and various proteoglycans and retain their in vitro immunocytochemical properties after transplantation. Despite the potential disadvantage of tumor formation by immortalized cells, it might be advantageous to use the astrocyte lines to stimulate axon growth.

\subsubsection{Olfactory Bulb Ensheathing Cells}

The olfactory bulb contains a special type of macroglia, the ensheathing glia, which appears to be responsible for the regenerative ability of olfactory axons (Doucette, 1990). Since ensheathing glia cells secrete NGF and express a variety of molecules which are known promoters of neurite initiation, attachment and growth (Ramon-Cuéto and NietoSampedro, 1992; Ramon-Cuéto et al., 1993), they are suggested to perform simultaneously the roles of both astrocytes and Schwann cells (Doucette and Devon, 1993). While combining the favorable characteristics of the latter cells, the ensheating cells are promising candidates for implantation into areas of CNS injury.

In fact recent implantation studies have confirmed the growth-promoting function of the ensheathing cells in vivo. They support the regeneration of:

1. dorsal root axons when placed inside semipermeable polymer tubes (Lustgarten et al., 1991) or implanted into the dorsal root entry zone (Ramon-Cuéto and Nieto-Sampedro, 1994);

2. cholinergic axons from the medial septal nucleus when implanted as ensheathing cell/collagen matrix following ablation of the fimbria fornix (Smale et al., 1996); and

3. corticospinal axons when injected into the lesion site (Li et al., 1997).

Another step towards clinical application is the recent establishment of a clonal olfactory bulbensheathing cell line (Goodman et al., 1993), which has been shown to produce peripheral-type myelin sheaths around demyelinated spinal cord axons (Franklin et al., 1996).

\subsubsection{Microglial Cells}

Microglial cells have long been known to play a key role in the regeneration process of CNS. However, the nature of their involvement in the regeneration is still a subject of controversy. Brain microglia are highly complex cells exhibiting multiple morphological forms and functional specializations [for reviews see Streit et al. (1988) and Thomas (1992)]. In addition to its immune function [for review see Perry et al. (1993)], microglia:

1. release neurotoxic substances (Giulian, 1993; Giulian et al., 1993), which might propagate further destruction of neurons, but also

2. remove the cellular debris from an area of degeneration (Giulian et al., 1989; Stoll et al., 1989) and secrete growth factors (Nagata et al., 1993), like NGF (Mallat et al., 1989), thrombospondin (Rabchevsky and Streit, 1997) and laminin (Rabchevsky and Streit, 1997), functions which suggest a beneficial role for these cells in regeneration.

According to these conflicting actions, the results of experimental microglia treatments are contradictory. While suppression of the microglial metabolic activity enhances axonal regeneration (Thanos et al., 1993), it has also been reported that addition of microglia or macrophages to CNS lesions (David et al., 1990; Lazarov-Spiegler et al., 1996; Rabchevsky and Streit, 1997; Prewitt et al., 1997; Frauzeu et al., 1998) overcomes CNS regeneration failure. In line with the latter data is the hypothesis; David et al., 1990 that the lack of a robust microglia/macrophage response in the lesioned adult mammalian CNS may account for the lack of significant axonal regeneration (Avellino et al., 1995). However, it will be of crucial relevance to perform additional experiments to define the role of microglial cells and to develop the microglia transplantation approach to a novel therapy for CNS injuries. 


\subsection{Neutralization of Neurite Growth Inhibitors}

A tremendous effort has been made to identify neurite growth inhibiting molecules (see Section 3.2). Currently the best characterized cells mediating inhibitory signals in axonal growth are oligodendrocytes. In a series of experiments it has been shown that the growth inhibitory nature of oligodendrocytes and myelin can at least be attributed to the myelin proteins NI-35 and NI-250 (NI, neurite inhibitor) as well as the myelin-associated glycoprotein (MAG) (Berry, 1982; Schwab and Thoenen, 1985; Schwab and Caroni, 1988; Bandtlow et al., 1990; Bastmeyer et al., 1991; McKerracher et al., 1994; Mukhopadhyay et al., 1994; Li et al., 1996). Based on this in vitro data it was hypothesized that the myelin molecules NI35/250 become exposed during the injury response and abort regeneration. Following, different attempts were started to reduce or neutralize these proteins. In one series of experiments myelin-free spinal cord has been produced in young rats by repeated X-irradiation (Savio and Schwab, 1990) or immunocytolysis (Keirstead et al., 1992). These treatments resulted in substantial elongation of regrowing corticospinal and brainstem descending projections. The studies further suggest that myelin proteins represent a major nonpermissive component of CNS tissue and may serve as 'border markers' that restrict the growth of neurites to appropriate regions and layers in the CNS and may also exert an inhibitory role in the context of regenerative neurite growth. In a second series of experiments antibodies against the myelin proteins NI$35 /-250$ were raised to neutralize the growth inhibitory activity of these proteins. The continuous application of these antibodies by implantation of living mouse antibody-secreting hybridomas either on top of a lesion or into the lateral ventricles restores elongation of some corticospinal, optic nerve and septo-hippocampal sprouts for considerable distances distal to the lesion site (Schnell and Schwab, 1990; Cadelli and Schwab, 1991; Schnell and Schwab, 1993; Weibel et al., 1994). Subsequent work has shown that coadministration of NT-3 enhances sprouting of lesioned fibers (Schnell et al., 1994) which correlates with significant recovery of certain motor functions (Bregman et al., 1995). In support of the growth-inhibitory role of myelin in the regeneration process are also recent observations of Cheng et al. (1996) and Tuszynski et al. (1996) in grafted spinal cord, where regenerating fibers extend only through gray matter and avoid to enter the white matter. Moreover, Eitan et al. (1994) showed that a single injection of the enzyme transglutaminase which triggers the apoptotic death of oligodendrocytes induced structural and partial functional recovery of transected optic nerve. Nonetheless, it has to be considered that in animals treated with antibodies against NI 35/250 the number of regenerating fibers is rather small and these fibers never succeeded in crossing through the lesion scar. Thus, the NI-glycoproteins seem to be important myelin components implicated in defining territories for axonal projections and hence are important target molecules for modulation once the fibers have passed the lesion site. However, these inhibitory molecules do not arrest axon growth at the lesion site, one major hurdle for axonal regeneration, and therefore, neutralization of these molecules may not be the prime target for strategies initiating axon regeneration at the lesion site.

Another component of myelin that has received much attention is MAG. While studies in MAGgene deficient mice do not support a role of MAG in regeneration failure (Bartsch, 1996), the physiological relevance of MAG remains to be determined by inhibition experiments in vivo.

\subsection{Reduction of Scarring}

Central nervous system destruction by injury leads to the formation of scars as in other organs of the body. Normal mature scarring is characterized by the deposition of a basement membrane formed by two independent networks (the collagen IV- and the laminin-network) and by astrocytosis and the permanent presence of mesodermal components like fibroblasts and macrophages (Berry et al., 1983). The relationship of the lesion scar and the failure of the mammalian CNS to regenerate has a long and controversial history. Since until recently it was unclear what aspects of this glial-mesodermal cicatrix comprises the barrier, a variety of manipulations have been tried to reduce scar tissue. Attempts include excision or reduction of the lesion scar, bridging the scar by cellular or noncellular grafts (see Section 5.3) and modification of either the gliotic or the basal membrane component of the scar.

Historically, the major approach to reduce the CNS scar has been the application of pharmacological agents. The first of these, a bacterial pyrogen, piromen, was utilized to reduce or alter the nature of cicatrix formation in transected spinal cord (Windle et al., 1951; Clemente, 1955). In many instances, treatment with these agents significantly altered scar formation and increased sprouting of new axons but the beneficial effects were temporary. Other classical approaches include injections of enzymes, like collagenase, trypsin or elastase to permeabilize the basal membrane of the scar (Freeman et al., 1960; Puchala and Windle, 1977; Guth et al., 1980) that mostly failed to significantly improve the conditions for neurite growth. One reason for this failure might be the unavoidable, additional attack of vascular basal membranes in the surrounding of the lesion, that might lead to severe changes in vascular supply to the damaged region.

More recent attempts to reduce scar formation are the use of $\mathrm{X}$-irradiation and the application of glucocorticoids or antibodies to transforming growth factor $\beta(\mathrm{TGF} \beta)$. X-Irradiation is an elegant, while noninvasive, approach to reduce the gliotic component of the scar by inhibition of cell proliferation and to prevent tissue degeneration around the lesion site (Kalderon et al., 1990b). This method has been successfully applied in transected spinal cord lesion and resulted in restitution of severed corticospinal axons (Kalderon and Fuks, 1996a) and recovery of control of hindlimb muscle (Kalderon and Fuks, 1996b). However, the regenerating axons did neither follow their previous pathway, that is important for reestablishment of topographic re- 

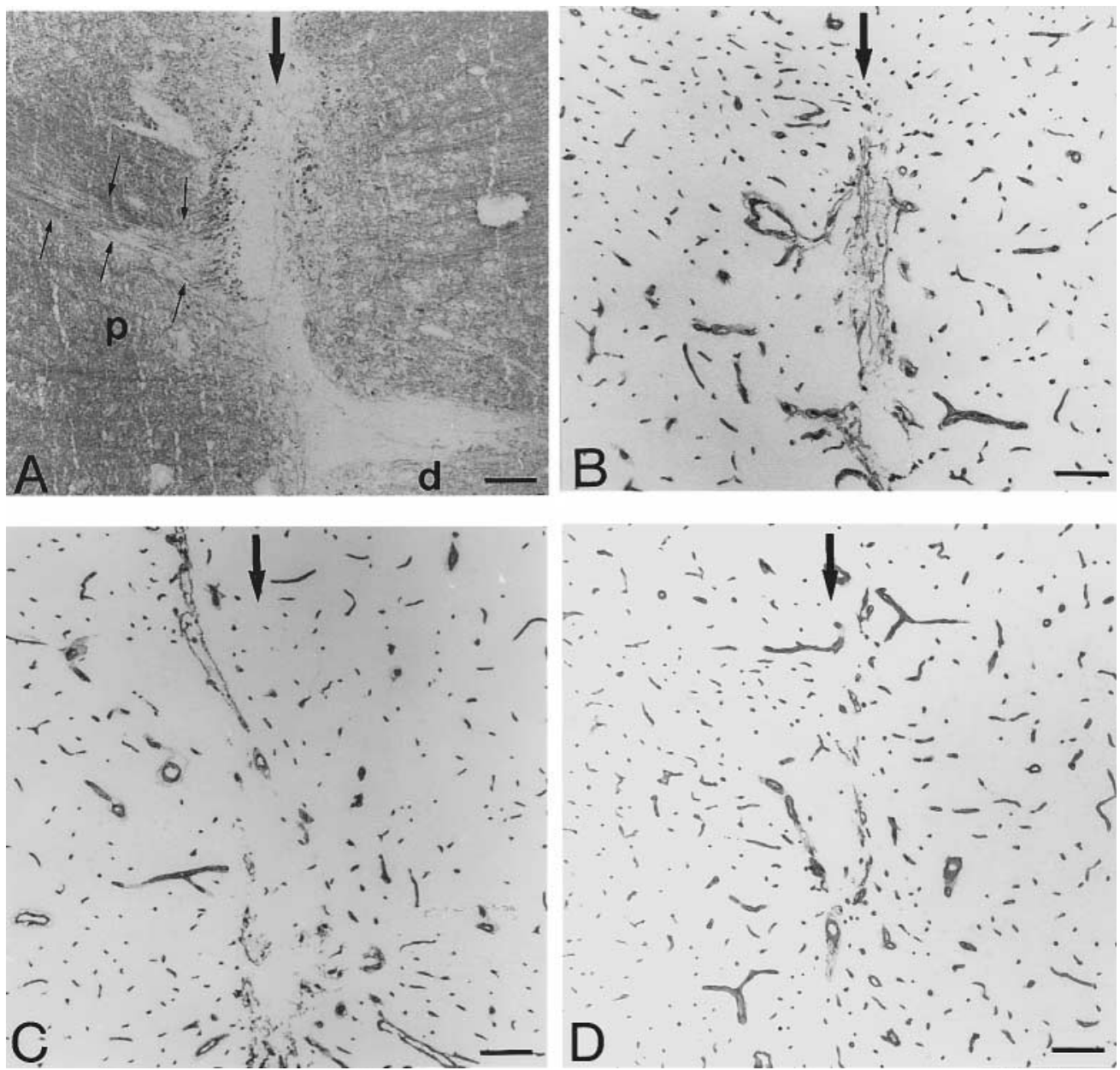

Fig. 6. Basal membrane deposition and axonal growth arrest. (A) At $c a 2$ weeks posttransection fornix axons stop at the former lesion site. (B) Adjacent section showing that at this time the lesion site is filled by an collagen IV immunoreactive basal membrane, which is oriented perpendicular to the trajectory of the tract and forms a continuous structure. Injections of anti-Coll IV antibodies (C) or dipyridyl (D) immediately after lesion prevent the formation of the basal membrane in the lesion center. Arrows indicate lesion/injection site. d; Distal, p; proximal. Scale bars $100 \mu \mathrm{m}$.

lationships, nor did they restore topographic and coordinated synaptic reinnervation of the target. While oligodendrocytes are also reduced within this glial-deficient environment and growth-promoting Schwann cells immigrate from the PNS this experimental approach does not provide unequivocal evidence that the scar it is the sole factor limiting axonal growth after injury.

Injections of glucocorticoids ( $\mathrm{Li}$ and David, 1996) or antibodies against TGF $\beta$ (Logan et al., 1994) affected the fibroblastic part of the scar but so far no analysis of axonal regeneration across the modified scar has been provided.

The overwhelming data on axonal growth stop at the lesion scar and the fact that the identity of the inhibitory scar constituent is still unclear prompted us to analyze and influence this axonal-scar relationship in a well-defined lesion model, the postcommissural fornix of the adult rat (Stichel et al., 1998) (Figs 6 and 7). Transected and retracted postcommissural fornix fibers spontaneously sprout up to the lesion site, where they stop abruptly [Fig. 3(B)Fig. 6(A)]. The spatio-temporal coinci- dence of this axonal arrest with the formation of a basal membrane in the lesion site [Fig. 6(B)] strongly suggests that the basal membrane is the inhibitory constituent of the impermeable scar. In an effort to reduce postlesion basal membrane deposition we injected locally either an antiserum to collagen IV or an iron-chelator, dipyridyl, that inhibits the enzyme prolylhydroxylase and thereby prevents formation of collagen fibrils. And in fact, we succeeded in reducing the basal membrane formation of the scar [Fig. 6(C and D)Fig. 7(A)] and this reduction was sufficient for elongation of large numbers of fibers across the lesion site [Fig. 7(B and C)]. The regenerating fibers reinnervated their normal target [Fig. 7(E and F)], were remyelinated [Fig. 7(D)] and regained normal conduction properties. Our study provided unequivocal evidence that:

1. the lesion scar and in particular the basal membrane impedes axonal regeneration in the adult mammalian CNS; and

2. CNS axons have an innate potential for regeneration and self-organization. 

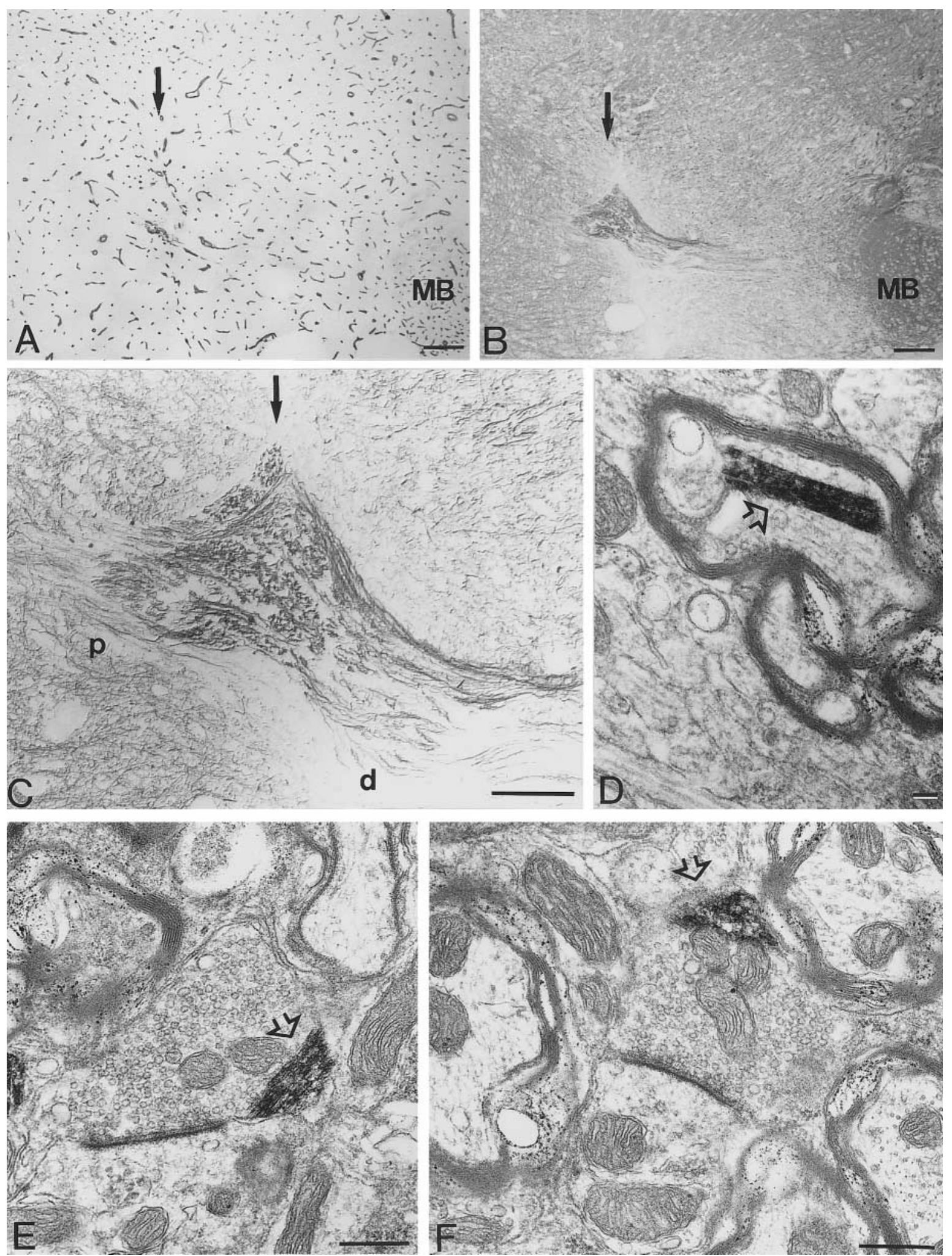

Fig. 7. Reduction of basal membrane formation promotes axonal elongation of transected postcommissural fornix axons across the lesion site. Animals with immediate local injection of dipyridyl into the transection site show reduced formation of a basal membrane in the lesion center (A) and successful regeneration across the lesion site (B). (C) High-magnification photomicrograph of fibers crossing the lesion/injection site shown in (B). Anterogradely labeling with WGA-HRP revealed that regenerating axons are remyelinated (D) and reinnervate their normal target (E and F). Filled arrows indicate the position of the lesion/injection site, open arrows mark the WGA-HRP reaction product. Scale bars $100 \mu \mathrm{m}$ (A-C), $0.1 \mu \mathrm{m}(\mathrm{D}), 0.5 \mu \mathrm{m}(\mathrm{E}$ and F). 
However, our experiments cannot determine the mechanism underlying this growth arrest mediated by the basal membrane. In addition to a possible mechanical barrier effect, several components with repulsive or inhibitory effects might be cross-linked to collagen and indirectly reduced by the alteration in collagen network formation. Now one of the key challenges to proceed this experimental strategy to clinical application is to analyze whether lesion scars in other brain regions or in the spinal cord can also be modified by the described treatment and whether this modification is sufficient also for other fiber tracts to overcome the major extrinsic constraint to axonal regeneration, the lesion scar.

\subsection{Electric Fields}

Nervous system tissue, both in vivo and in vitro, respond to an applied d.c. electric field. In vitro, weak electric fields stimulate neurite sprouting (Hinkle et al., 1981), induce growth cone turning (Hinkle et al., 1981; Patel and Poo, 1982; Erskine et al., 1995), enhance nerve growth rates (McCaig, 1990a; Erskine et al., 1995), enhance and direct neurite branching (McCaig, 1990b; Erskine et al., 1995) and alter the distribution of growth cone filopodia (McCaig, 1986, 1987). In vivo responses to an electric field include increases in rate of neurite growth, orientation of neurites towards the negative pole of an electric field, increases in the amount of branching of axons and a decrease in axonal dieback (Borgens, 1982; Roederer et al., 1983). However, the cellular mechanisms underlying these pronounced effects are completely unknown and only a few speculations were made, which are, a reduction of retrograde axonal degeneration by reducing the injury current-mediated dieback (Borgens et al., 1979; Borgens, 1982); electrophoresis of membrane components (Poo and Robinson, 1977; Orida and Poo, 1978), that may be critical to axonal growth; electrophoresis of intra-axonal components (Borgens, 1982) and perhaps effects on the glial architecture of the scar (Borgens et al., 1994).

While most studies have been performed in a variety of nonmammalian vertebrates (Marsh and Beams, 1946; Borgens et al., 1979; Jaffe and Poo, 1979; Roederer et al., 1983), applied electrical fields have also proved effective in promoting neuronal regeneration in adult mammalian CNS. Studies of Borgens et al. $(1987,1990)$ in the adult guinea pig and those of Fehlings and coworkers in the adult rat (Fehlings et al., 1988; Fehlings and Tator, 1992) provide solid support that an electric field applied across hemisectioned spinal cord leads to some functional recovery. However, electric field-treated spinal cords contained only some axons that regenerated across the plane of transection, while most axons passed around the lesion site and elongated within the outer rim of the spinal cord which typically survives impact (Borgens and Bohnert, 1997). It seems necessary to examine the possibility of synergistic effects between fields and glial implants or pharmacological treatment, to increase the intensity of the regenerative response.

\subsection{Combined Strategies}

On the basis of the studies discussed in Sections 5.1, 5.2, 5.3, 5.4, 5.5 and 5.6 it is apparent that, except for some very rare cases (Stichel et al., 1997), the application of a single intervention strategy is insufficient to ensure structural regeneration and recovery of function of a lesioned CNS fiber tract. Studies in the spinal cord have shown that even under conditions of little scarring and an acceptable growth environment, substantial growth of some of the long tracts does not occur (Tuszynski et al., 1994; Xu et al., 1995a; Nakahara et al., 1996; Tuszynski et al., 1996). Particular populations of neurons have specific requirements for regenerative growth. At least in the spinal cord it seems that a cocktail of strategies is required for anatomic reorganization.

In order to increase the capacity for axonal growth one type of approach is to apply NTFs in combination with growth promoting cells. Thus, administration of neurotrophic factors together with growth-promoting cells, like Schwann cells or PN graft (Varon and Conner, 1994; Xu et al., 1995a,b; Cheng et al., 1996; Guest et al., 1997) improved the regenerative growth of long descending pathways compared to single growth-promoting approaches. Recently, Meuei and coworkers (1998) implanted Schwann cells genetically modified to express BDNF, which resulted in an enhanced regeneration of brainstem neurons. In a second type of combined approach, NTFs were applied together with antibodies to growth-inhibitory molecules to alter the environment of the lesion site (Schnell et al., 1994), which enhanced the regenerative sprouting of the corticospinal tract. These studies and those of Tuszynski and coworkers (Tuszynski et al., 1994; Nakahara et al., 1996; Tuszynski et al., 1996; Grill et al., 1997) in spinal cord clearly indicate that the influence of the neurotrophins on mature injured CNS neurons is not uniform. Rather, particular populations of neurons appear to respond preferentially to particular members of the neurotrophin family (Table 2). The identification of optimal combinations of NTF(s) and growth substrates may be a useful strategy to improve axonal regeneration in adult CNS.

Another combination approach is the simultaneous application of antibodies to growth-inhibitory molecules and the implantation of a fetal graft (Schnell et al., 1994) or Schwann cells (Guest et al., 1997) into the lesion site. The fetal graft + IN1 combination attempted to guide the elongating axons across the lesion site, but it failed since regrowing fibers always crossed the lesion site through remaining tissue bridges. The other combination (Schwann cells + IN1) also failed to support corticospinal tract regeneration. With regard to this issue one might assume that the combination of the scar reducing approach using anti-collagen IV antibodies or dipyridyl with the application of NTFs and/or antibodies against NI35/250 may be an exciting and promising 'cocktail approach' to restore functional deficits in the lesioned spinal cord.

\section{CLINICAL PERSPECTIVES}

The many basic science studies reviewed suggest that restoration of physiological function after trau- 
matic CNS injury is feasible. However, as a therapeutic strategy in human disorders and injuries any approach to stimulate axonal regrowth is still in its infancy. While large clinical trials to evaluate pharmacological treatments of secondary damage following spinal cord trauma are performed since 1975 (NASCIS, national acute spinal cord studies) (Bracken et al., 1984, 1990, 1997), the approaches focusing on axonal regrowth still remain on a purely experimental animal level at present. Extrapolation of the experimental data to the human situation will have to confront the issues of larger and more complex lesions, longer pathway distances and the sideeffects of the various growth-stimulating procedures. On the other hand, it has been shown that as little as $5-10 \%$ of a particular pathway can often sustain recovery of function (Fehlings and Tator, 1995), implying that even modest axonal growth may have sufficient functional impact. There is much cause for optimism and it is now a matter of time and planning and designing new experiments to create the most effective 'cocktail(s)' for CNS regeneration.

Acknowledgements - This work was supported by a grant from the Deutsche Forschungsgemeinschaft (SFB 194/B5) and a Heisenberg stipendium to C.C.S.

\section{REFERENCES}

Acheson, A., Barker, P. A., Alderson, R. F., Miller, F. D. and Murphey, R. A. (1991) Detection of brain-derived neurotrophic factor-like activity in fibroblasts and Schwann cells, inhibition by antibodies to NGF. Neuron 7, 265-275.

Adams, R. D. and Victor, M. (1985) Disease of the spinal cord. In: Principles of Neurology, pp. 665-698. Eds. R. D. Adams and M. Victor. McGraw-Hill Book Company, New York.

Aebischer, P., Guénard, V., Winn, S. R., Valentini, R. F. and Galetti, P. M. (1988) Blind ended semi-permeable guidance channels support peripheral nerve regeneration in the absence of a distal nerve stump. Brain Res. 454, 179-187.

Ahmed, S., Reynolds, B. A. and Weiss, S. (1995) BDNF enhances the differentiation but not the survival of CNS stem cell-derived neuronal precursors. J. Neurosci. 15, 5765-5778.

Aigner, L., Arber, S., Kapfhammer, J. P., Laux, T., Schneider, C., Botteri, F., Brenner, H.-R. and Caroni, P. (1995) Overexpression of the neural growth-associated protein GAP-43 induces nerve sprouting in the adult nervous system of transgenic mice. Cell 83, 269-278.

Ajemian, A., Ness, R. and David, S. (1994) Tenascin in the injured rat optic nerve and in non-neuronal cells in vitro, potential role in neural repair. J. Comp. Neurol. 340, 233-242.

Alderson, R. F., Alterman, A. L., Barde, Y. A. and Lindsay, R. M. (1990) Brain-derived neurotrophic factor increases survival and differentiated functions of rat septal cholinergic neurons in culture. Neuron 5, 297-306.

Alderson, R. F., Wiegand, S. J., Anderson, K. D., Cai, N., Cho, J. Y., Lindsay, R. M. and Altar, C. A. (1996) Neurotrophin-4/5 maintains the cholinergic phenotype of axotomized septal neurons. Eur. J. Neurosci. 8, 282-290.

Alonso, G. and Privat, A. (1993) Reactive astrocytes involved in the formation of lesional scars differ in the mediobasal hypothalamus and in other forebrain regions. J. Neurosci. Res. 34, 523-538.

Anders, J. J. and Hurlock, J. A. (1996) Transplanted glial scar impedes olfactory bulb reinnervation. Exp. Neurol. 142, 144 150.

Asada, H., Kaseloo, P. A., Lis, A., Petti, D. M. and Plunkett, R. J. (1996) Traumatized rat striatum produces neurite-promoting and neurotrophic activities in vitro. Exp. Neurol. 139, 173-187.

Aubert, I., Ridet, J.-L. and Gage, F. H. (1995) Regeneration in the adult mammalian CNS, guided by development. Curr. Opin. Neurobiol. 5, 625-635.
Auger, M. J. and Ross, J. A. (1992) The biology of the macrophage. In: The macrophage, pp. 1-74. Eds. C. E. Lewis and J. O. McGee. Oxford University Press, Oxford

Avellino, A. M., Hart, D., Dailey, A. T., MacKinnon, M., Ellegala, D. and Klio, M. (1995) Differential macrophage responses in the peripheral and central nervous system during Wallerian degeneration of axons. Exp. Neurol. 136, 183-198.

Bähr, M., Vanselow, J. and Thanos, S. (1989) Ability of adult rat ganglion cells to regrow axons in vitro can be influenced by fibroblast growth factor and gangliosides. Neurosci. Lett. 96, 197-201.

Bähr, M. and Bonhoeffer, F. (1994) Perspectives on axonal regeneration in the mammalian CNS. TINS 17, 473-479.

Baier, H. and Bonhoeffer, F. (1992) Axon guidance by gradients of a target-derived component. Science 255, 472-475.

Baird, A., Trenkner, E. and Mason, C. A. (1996) Arrest of afferent axon extension by target neurons in vitro is regulated by the NMDA receptor. J. Neurosci. 16, 2642-2648.

Banati, R. B., Gehrmann, J., Schubert, P. and Kreutzberg, G. W. (1993) Cytotoxicity of microglia. Glia 7, 111-118.

Bandtlow, C. E., Heumann, R., Schwab, M. E. and Thoenen, H. (1987) Cellular localization of nerve growth factor synthesis by in situ hybridization. EMBO J. 6, 891-899.

Bandtlow, C. E., Zachleder, T. and Schwab, M. E. (1990) Oligodendrocytes arrest neurite growth by contact inhibition. $J$. Neurosci. 10, 3937-3948.

Barde, Y. A. (1990) The nerve growth factor family. Prog. Growth Factor Res. 2, 237-248.

Barker, R. A., Dunnett, S. B. and Fawcett, J. W. (1993) Neurotrophic factors and neural grafts, a growing field. Sem. Neurosci. 5, 431-441.

Bartsch, U. (1996) Myelination and axonal regeneration in the central nervous system of mice deficient in the myelin-associated glycoprotein. J. Neurocytol. 25, 303-313.

Bartsch, U., Bartsch, S., Dörries, U. and Schachner, M. (1992) Immunhistochemical localization of tenascin in the developing and lesioned adult mouse optic nerve. Eur. J. Neurosci. 4, 338 353.

Bastmeyer, M., Beckmann, M., Schwab, M. E. and Stürmer, C. A. O. (1991) Growth of regenerating goldfish axons is inhibited by rat oligodendrocytes and CNS myelin but not by goldfish optic nerve tract oligodendrocyte-like cells and fish CNS myelin. $J$. Neurosci. 11, 626-640.

Benowitz, L. I. and Routtenberg, A. (1997) GAP-43, an intrinsic determinant of neuronal development and plasticity. TINS 20, 84-91.

Bernstein, J. J. and Bernstein, M. E. (1971) Axonal regeneration and formation of synapses proximal to the site of lesion following hemisection of the rat spinal cord. Exp. Neurol. 30, 336351 .

Bernstein, J. J. and Goldberg, W. J. (1989) Rapid migration of grafted cortical astrocytes from suspension grafts placed in host thoracic spinal cord. Brain Res. 14, 205-211.

Bernstein, J. J. and Goldberg, W. J. (1991) Grafted fetal astrocyte migration can prevent host neuronal atrophy, comparison of astrocytes from cultures and whole piece donors. Rest. Neurol. Neurosci. 2, 261-270.

Berry, M. (1982) Post-injury breakdown products inhibit axonal growth; an hypothesis to explain the failure of axonal regeneration in the mammalian central nervous system. Bibl. Anat. 23, $1-11$.

Berry, M., Maxwell, W. L., Mathewson, A., McConnell, P., Ashhurst, D. E. and Thomas, G. E. (1983) Deposition of scar tissue in the central nervous system. Acta Neurochir. 32(Suppl.), 31-53.

Berry, M., Rees, L., Hall, S., Yiu, P. and Sievers, J. (1988) Optic axons regenerate into sciatic nerve isografts only in the presence of Schwann cells. Brain Res. Bull. 20, 223-231.

Berry, M., Carlile, J. and Hunter, A. (1996a) Peripheral nerve explants grafted into the vitreous body of the eye promote the regeneration of retinal ganglion cell axons severed in the optic nerve. J. Neurocytol. 25, 147-170.

Berry, M., Maxwell, W. L., Mathewson, A., McConnell, P., Ashhurst, D. E. and Thomas, G. E. (1996b) Deposition of scar tissue in the central nervous system. Acta Neurochir. 32(Suppl.), 31-53.

Bignami, A. and Eng, L. F. (1973) Biochemical studies of myelin in wallerian degeneration of the optic nerve. J. Neurochem. 20, $165-173$.

Bignami, A., Dahl, D., Nguyen, B. T. and Crosby, C. J. (1981) The fate of axonal debris in Wallerian degeneration of rat optic and sciatic nerves. J. Neuropathol. Exp. Neurol. 40, 537-550. 
Bisby, M. A. and Tetzlaff, W. (1992) Changes in cytoskeletal protein synthesis following axon injury and during axon regeneration. Mol. Neurobiol. 6, 107-123.

Blakemore, W. F. (1977) Remyelination of CNS axons by Schwann cells transplanted from the sciatic nerve. Nature 266, 68-69.

Blight, A. R. (1991) Morphometric analysis of blood vessels in chronic experimental spinal cord injury, hypervascularity and recovery of function. J. Neurol. Sci. 106, 158-174.

Borgens, R. B. (1982) What is the role of naturally produced electric current in vertebrate regeneration and healing? Int. Rev. Cytol. 76, 245-298.

Borgens, R. B. and Bohnert, D. M. (1997) The responses of mammalian spinal axons to an applied DC voltage gradient. Exp. Neurol. 145, 376-389.

Borgens, R. B., Vanable, J. W. and Jaffe, L. F. (1979) Small artificial currents enhance Xenopus limb regeneration. J. Exp. Zool. 207, 217-255

Borgens, R. B., Blight, A. R. and Murphy, D. J. (1986) Axonal regeneration in spinal cord injury, a perspective and new technique. J. Comp. Neurol. 250, 157-167.

Borgens, R. B., Blight, A. R. and McGinnis, M. E. (1987) Behavioral recovery induced by applied electric fields after spinal cord hemisection in guinea pig. Science 238, 366-369.

Borgens, R. B., Blight, A. R. and McGinnis, M. E. (1990) Functional recovery after spinal cord hemisection in guinea pigs, the effects of applied electric fields. J. Comp. Neurol. 296, 634-653.

Borgens, R. B., Shi, R., Mohr, T. J. and Jaeger, C. B. (1994) Mammalian cortical astrocytes align themselves in a physiological voltage gradient. Exp. Neurol. 128, 41-49.

Bothwell, M. (1995) Functional interactions of neurotrophins and neurotrophin receptors. Annu. Rev. Neurosci. 18, 223-253.

Bovolenta, P., Wandosell, F. and Nieto-Sampedro, N. (1993) Characterization of a neurite outgrowth inhibitor expressed after CNS injury. Eur. J. Neurosci. 5, 454-465.

Bracken, M. B., Collins, W. F., Freeman, D. F., Shepard, M. J., Wagner, F. W., Silten, R. M., Hellengrand, K. G., Ransohoff, J., Hunt, W. E., Perot, P. L., Grossman, R. G., Green, B. A., Eisenberg, H. M., Rifkinson, N., Goodman, J. H., Meagher, J. N., Fischer, B., Clifton, G. L., Flamm, E. S. and Rave, S. E. (1984) Efficacy of methylprednisolone in acute spinal cord injury. J. Am. Med. Assoc. 251, 45-52.

Bracken, M. B., Shepard, M. J., Collins, W. F., Holford, T. R., Young, W., Baskin, D. S., Eisenberg, H. M., Flamm, E., LeoSummers, L., Maroon, J., Marshall, L. F., Perot, P. L., Piepmeier, J., Sonntag, V. K. H., Wagner, F. C., Wilberger, J. E. and Winn, H. R. (1990) A randomized, controlled trial of methylprednisolone or naloxone in the treatment of acute spinal cord injury. N. Engl. J. Med. 322, 1405-1411.

Bracken, M. B., Shepard, M. J., Holford, T. R., Leo-Summers, L., Aldrich, E. F., Fazl, M., Fehlings, M., Herr, D. L., Hitchon, P. W., Marshall, L. F., Nockels, R. P., Pascale, V., Perot, P. L., Piepmeier, J., Sonntag, V. K. H., Wagner, F., Wilberger, J. E., Winn, H. R. and Young, W. (1997) Administration of methylprednisolone for 24 or 48 hours or tirilazad mesylate for 48 hours in the treatment of acute spinal cord injury. J. Am. Med. Assoc. 277, 1597-1604.

Bray, G. M., Vidal-Sanz, M., Villegas-Pérez, M. P., Carter, D. A., Zcwimpfer, T. and Aguayo, A. J. (1992) Growth and differentiation of regenerating CNS axons in adult mammals. In: The Nerve Growth Cone, pp. 489-504. Eds. P. C. Letourneau, S. B. Kater and E. R. Macagno. Raven Press, New York.

Brecknell, J. E., Du, J. S., Muir, E., Fider, P. S., Hlavins, M. L., Dunnett, S. B. and Fawcett, J. W. (1996) Bridge grafts of fibroblast growth factor-4-secreting Schwannoma cells promote functional axonal regeneration in the nigrostriatal pathway of the adult rat. Neuroscience 74, 775-784.

Bregman, B. S. and Reier, P. J. (1986) Neural tissue transplants rescue axotomized rubrospinal cells from retrograde death. $J$. Comp. Neurol. 244, 86-95.

Bregman, B. S., Kunkel-Badgen, E., Schnell, L., Dai, H. N., Gao, D. and Schwab, M. E. (1995) Recovery from spinal cord injury mediated by antibodies to neurite growth inhibitors. Nature 378, 498-501.

Brodkey, J. A., Gates, M. A., Laywell, E. D. and Steindler, D. A. (1993) The complex nature of interactive neuroregeneration-related molecules. Exp. Neurol. 123, 251-270.

Brook, G. A., Lawrence, J. M. and Raisman, G. (1993) Morphology and migration of cultured Schwann cells transplanted into the fimbria and hippocampus in adult rats. Glia $\mathbf{9}$, 292-304.
Brook, G. A., Lawrence, J. M., Shah, B. and Raisman, G. (1994) Extrusion transplantation of Schwann cells into the adult rat thalamus induces directional host axon growth. Exp. Neurol. 126, 31-43.

Brundin, P. and Wictorin, K. (1993) Neuronal transplantation in rats models of Parkinson's and Huntington's disease. Sem. Neurosci. 5, 413-421.

Bunge, M. B. (1993) Schwann cell regulation of extracellular matrix biosynthesis and assembly. In: Peripheral Neuropathy, pp. 299-316. Ed. P. Dyck. Saunders, Philadelphia.

Byrnes, A. P., Rusby, J. E., Wood, M. J. and Charlton, H. M (1995) Adenovirus gene transfer causes inflammation in the brain. Neuroscience 66, 1015-1024.

Cadelli, D. and Schwab, M. E. (1991) Regeneration of lesioned septohippocampal acetylcholinesterase-positive axons is improved by antibodies against the myelin-associated neurite growth inhibitor NI 35/250. Eur. J. Neurosci. 3, 825-832.

Carbonetto, S., Gruver, M. M. and Turner, D. C. (1983) Nerve fiber growth in culture on fibronectin, collagen and glycosaminoglycan substrates. $J$. Neurosci. 3, 2324-2335.

Caroni, P. (1997) Intrinsic neuronal determinants that promote axonal sprouting and elongation. BioEssays 19, 767-775.

Carter, D. A. and Jhaveri, S. (1997) Retino-geniculate axons regenerating in adult hamsters are able to form morphologically distinct terminals. Exp. Neurol. 146, 315-322.

Carter, D. A., Bray, G. M. and Aguayo, A. J. (1994) Long-term growth and remodeling of regenerated retino-collicular connections in adult hamsters. J. Neurosci. 14, 590-598.

Casella, G. T. B., Bunge, R. P. and Wood, P. M. (1996) Improved method for harvesting human Schwann cells from mature peripheral nerve and expansion in vitro. Glia 17, 327-338.

Chao, H. M. and McEwen, B. S. (1994) Glucocorticoids and the expression of mRNAs for neurotrophins, their receptors and GAP-43 in the rat hippocampus. Brain Res. Mol. Brain Res. 26, 271-276.

Chen, A., Xu, X. M., Kleitman, N. and Bunge, M. B. (1996) Methylprednisolone administration improves axonal regeneration into Schwann cell grafts in transected adult rat thoracic spinal cord. Exp. Neurol. 138, 261-276.

Chen, D. F., Jhaveri, S. and Schneider, G. E. (1995) Intrinsic changes in developing retinal neurons result in regenerative failure of their axons. Proc. Natl Acad. Sci. U.S.A. 92, 7287-7291.

Chen, D. F., Schneider, G. E., Martinon, J.-C. and Tonegawa, S (1997) Bcl-2 promotes regeneration of severed axons in mammalian CNS. Nature 385, 434-439.

Chen, M., Harvey, A. R. and Dyson, S. E. (1991) Regrowth of lesioned retinal axons associated with the transplantation of Schwann cells to the brachial region of the rat optic tract. Res. Neurol. Neurosci. 2, 233-248.

Cheng, H., Cao, Y. and Olson, L. (1996) Spinal cord repair in adult paraplegic rats, partial restoration of hind limb function. Science 273, 510-513.

Christner, J. E., Caterson, B. and Baker, J. R. (1980) Immunological determinants of proteoglycans. J. Biol. Chem. 255, 7102-7105.

Chuong, C. M. and Chen, H. M. (1991) Enhanced expression of neural cell adhesion molecules and tenascin (cytotactin) during wound healing. Am. J. Pathol. 138, 427-440.

Clemente, C. D. (1955) Structural regeneration in the mammalian central nervous system and the role of neuroglia and connective tissue. In: Regeneration in the Nervous System, pp. 147-161. Ed. W. F. Windle. Charles C. Thomas, Springfield, IL.

Coffey, E. T., Akerman, K. E. and Courtney, M. J. (1997) Brain derived neurotrophic factor induces a rapid upregulation of synaptophysin and tau proteins via the neurotrophin receptor TrkB in rat cerebellar granule cells. Neurosci. Lett. 227, 177180

Cohen, A., Bray, G. M. and Aguayo, A. J. (1994) Neurotrophin$4 / 5(\mathrm{NT}-4 / 5)$ increases adult rat retinal ganglion cell survival and neurite outgrowth in vitro. J. Neurobiol. 25, 953-959.

Cohen, A. H., Mackler, S. A. and Selzer, M. E. (1988) Behavioral recovery following spinal transection, functional regeneration in the lamprey CNS. TINS 11, 227-231.

Cohen, R. W., Goodlick, T. and Kromer, L. F. (1990) Immunocytochemical characterization of CNS axonal regeneration through transplants of Schwann cell/matrix cables. Soc. Neurosci. Abstr. 16, 1282

Cole, G. J. and McCabe, C. F. (1991) Identification of a developmentally regulated keratan sulfate proteoglycan that inhibits cell adhesion and neurite outgrowth. Neuron 7, 10xy7-10xy.

Condorelli, D. F., Dell'Albani, P., Kaczmarek, L., Messina, L., Spampinato, G., Avola, R., Messina, A. and Giuffrida Stella, 
A. M. (1990) Glial fibrillary acidic protein messenger RNA and glutamine synthetase activity after nervous system injury. $J$. Neurosci. Res. 26, 251-257.

Conner, J. M. and Varon, S. (1994) Nerve growth factor influences the distribution of sprouting sympathetic terminals in the hippocampal formation following cholinergic deafferentation. Exp. Neurol. 130, 15-23.

Conner, J. M. and Varon, S. (1995) Effects of exogenous nerve growth factor upon sympathetic sprouting into the hippocampal formation. Exp. Neurol. 136, 123-135.

Crossin, K. L., Hoffman, S., Tan, S.-S. and Edelman, G. M. (1989) Cytotactin and its proteoglycan ligand mark structural and functional boundaries in somatosensory cortex of the early postnatal mouse. Dev. Biol. 136, 381-392.

David, S. and Aguayo, A. J. (1981) Axonal elongation into peripheral nervous system "bridges" after central nervous system injury in adult rats. Science 214, 931-933.

David, S., Bouchard, C., Tsatas, O. and Giftochristos, N. (1990) Macrophages can modify the nonpermissive nature of the adult mammalian central nervous system. Neuron 5, 463-469.

Davies, S. J. A., Field, P. M. and Raisman, G. (1993) Long fibre growth by axons of embryonic mouse hippocampal neurons microtransplanted into the adult rat fimbria. Eur. J. Neurosci. 5, 95-106.

Davies, S. J. A., Fitch, M. T., Memberg, S. P., Hall, A. K., Raisman, G. and Silver, J. (1997) Regeneration of adult axons in white matter tracts of the central nervous system. Nature 390, 680-683.

Davis, G. R. J. and McCellan, D. (1994) Long distance axonal regeneration of identified lamprey reticulospinal neurons. Exp. Neurol. 127, 94-105.

De Witt, D. A., Richey, P. L., Praprotnik, D., Silver, J. and Perry, G. (1994) Chondroitin sulfate proteoglycans are a common component of neuronal inclusions and astrocytic reaction in neurodegenerative disease. Brain Res. 656, 205-209.

Dodd, J. and Schuchardt, A. (1995) Axon guidance, a compelling case for repelling growth cones. Cell 81, 471-474.

Doering, L. C. (1996) Towards gene therapy in the nervous system. Clin. Neurosci. 3, 259-261.

Doster, S. K., Lozano, A. M., Aguayo, A. J. and Willard, M. B. (1991) Expression of the growth-associated protein GAP-43 in adult rat retinal ganglion cells following axon injury. Neuron $\mathbf{6}$, 635-647.

Doucette, R. (1990) Glial influences on axonal growth in the primary olfactory system. Glia 3, 433-449.

Doucette, R. and Devon, R. (1993) Olfactory ensheating cells, factors influencing the phenotype of these glial cells. In: Biology and Pathology of Astrocyte-Neuron Interactions, pp. 117-124. Eds. S. Fedoroff, B. H. J. Juurlink and R. Doucette. Plenum Press, New York.

Duncan, I. D., Aguayo, A. J., Bunge, R. P. and Wood, P. M. (1981) Transplantation of rat Schwann cells grown in tissue culture into the mouse spinal cord. J. Neurol. Sci. 49, 241-252.

Dusart, I. and Schwab, M. E. (1994) Secondary cell death and the inflammatory reaction after dorsal hemisection of the rat spinal cord. Eur. J. Neurosci. 6, 712-724.

Dusart, I., Airaksinen, M. S. and Sotelo, C. (1997) Purkinje cell survival and axonal regeneration are age dependent: an in vitro study. J. Neurosci. 17, 3710-3725.

Eddleston, M. and Mucke, L. (1993) Molecular profile of reactive astrocytes -implications for their role in neurologic disease. Neuroscience 54, 15-36.

Edgar, D., Timpl, R. and Thoenen, H. (1984) The heparin-binding domain of laminin is responsible for its effects on neurite outgrowth and neuronal survival. EMBO J. 3, 1463-1468.

Egan, R. A. and Vijayan, V. K. (1991) Fibronectin immunoreactivity in neural trauma. Brain Res. 568, 330-334.

Eitan, S., Solomon, A., Lavie, V., Yoles, E., Hirschberg, D. L., Belkin, M. and Schwartz, M. (1994) Recovery of visual response of injured adult rat optic nerves treated with transglutaminase. Science 264, 1764-1768.

Emerich, D. F., Winn, S. R., Harper, J., Hammang, J. P., Baetge, E. E. and Kordower, J. H. (1994) Implants of polymer-encasulated human NGF-secreting cells in nonhuman primate, rescue and sprouting of degenerating cholinergic basal forebrain neurons. J. Comp. Neurol. 349, 148-164.

Emmett, C. J., Jaques-Berg, W. and Seeley, P. L. (1990) Microtransplantation of neural cells into the adult rat brain. Neuroscience 38, 213-222.

Emmett, C. J., Stewart, G. R., Johnson, R. M., Aswani, S. P., Chan, R. L. and Jakeman, L. B. (1996) Distribution of radioiodinated recombinant human nerve growth factor in primate brain following intracerebroventricular infusion. Exp. Neurol. 140, 151-160.

Erskine, L., Stewart, R. and McCaig, C. D. (1995) Electric field-directed growth and branching of cultured frog nerves, effects of aminoglycosides and polycations. J. Neurobiol. 26, 523-536.

Fagiolini, M., Pizzorusso, T., Porciatti, V., Cenni, M. and Maffei, L. (1997) Transplant of Schwann cells allows normal development of the visual cortex of dark-reared rats. Eur. J. Neurosci. 9, $102-112$.

Faissner, A. and Steindler, D. (1995) Boundaries and inhibitory molecules in developing neural tissues. Glia 13, 233-254.

Faissner, A., Kruse, J., Kühne, K. and Schachner, M. (1990) Binding of the $\mathrm{J} 1$ adhesion molecules to extracellular matrix constituents. J. Neurochem. 54, 1004-1015.

Fawcett, J. W. (1992) Intrinsic neuronal determinants of regeneration. TINS 15, 5-8.

Fedoroff, H. J., Geschwind, M. G., Geller, A. I. and Kessler, J. A. (1992) Expression of nerve growth factor in vivo from a defective herpes simplex virus prevents effects of axotomy on sympathetic ganglia. Proc. Natl Acad. Sci. U.S.A. 89, 1636-1640.

Fehlings, M. G. and Tator, C. H. (1992) The effect of direct current field polarity on recovery after acute experimental spinal cord injury. Brain Res. 579, 32-42.

Fehlings, M. G. and Tator, C. H. (1995) The relationships among the severity of spinal cord injury, residual neurological function, axon counts, and counts of retrogradely labeled neurons after experimental spinal cord injury. Exp. Neurol. 132, 220-228.

Fehlings, M. G., Tator, C. H. and Linden, R. D. (1988) The effect of direct-current field on recovery from experimental spinal cord injury. J. Neurosurg. 68, 781-792.

Felts, P. A. and Smith, K. J. (1992) Conduction properties of central nerve fibers remyelinated by Schwann cells. Brain Res. 574, 178-192.

Ferguson, I. A. and Johnson, E. M., Jr (1991) Fibroblast growth factor receptor-bearing neurons in the CNS: identification by receptor-mediated retrograde transport. J. Comp. Neurol. 313, 693-706.

Ferhat, L., Represa, A., Zouaoui-Aggoun, D., Ferhat, W., BenAri, Y. and Khrestchatisky, M. (1997) FGF-2 induces nerve growth factor expression in cultured rat hippocampal neurons Eur. J. Neurosci. 9, 1282-1289.

Feringa, E. R., Kowalski, T. F. and Vahlsing, H. L. (1980) Basal lamina formation at the site of spinal cord transection. Ann. Neurol. 8, 148-154.

Feringa, E. R., Kowalski, T. F. and Vahlsing, H. L. (1985) Basal lamina at the site of spinal cord injury in normal immunotolerant and immunsuppressed rats. Neurosci. Lett. 54, 225-230.

Fernaud-Espinosa, I., Nieto-Sampedro, N. and Bovolenta, P. (1993) Differential activation of microglia and astrocytes in aniso- and isomorphic gliotic tissue. Glia 8, 277-291.

Ferrari, G. and Greene, L. A. (1996) Prevention of neuronal apoptotic death by neurotrophic agents and ganglioside GM1, insights and speculations regarding a common mechanism. Persp. Dev. Neurobiol. 3, 93-100.

Flaccus, A., Janetzko, A., Tekotte, H., Margolis, R. K. and Margolis, R. U. (1991) Immunocytochemical localization of chondroitin and chondroitin 4- and 6-sulfates in developing rat cerebellum. J. Neurochem. 56, 1608-1615.

Fok-Seang, J., Smith-Thomas, L. C., Meiners, S., Muir, E. D., J S., Housden, E., Johnson, A. R., Faissner, A., Geller, H. M. and Keynes, R. J. (1995) An analysis of astrocytic cell lines with different abilities to promote axon growth. Brain Res. 689, 207-223.

Fournier, A. E. and McKerracher, L. (1995) Tubulin expression and axonal transport in injured and regenerating neurons in the adult mammalian central nervous system. Biochem. Cell. Biol. 73, 659-664

Frank, M. and Wolburg, H. (1996) Cellular reactions at the lesion site after crushing of the rat optic nerve. Glia 16, 227-240.

Franklin, R. J. M., Gilson, J. M., Franceschini, I. A. and Barnett, S. C. (1996) Schwann cell-like myelination following transplantation of an olfactory bulb-ensheathing cell line into areas of demyelination in the adult CNS. Glia 17, 217-224.

Franzen, R., Schoenen, J., Leprince, P., Joosten, E. A., Moonen, G. and Martin, D. (1998) Effects of macrophage transplantation in the injured adult rat spinal cord: a combined immunocytochemical and biochemical study. J. Neurosci Res, 51, 316-327.

Frautschy, S. A., Walicke, P. A. and Baird, A. (1991) Localization of basic fibroblast growth factor and its mRNA after CNS injury. Brain Res. 553, 291-299. 
Freed, W. J. (1991) Substantia nigra grafts and Parkinson's disease, from animal experiments to human therapeutical trials. Rest. Neurol. Neurosci. 3, 109-134.

Freed, W. J., de Medinacelli, L. and Wyatt, R. J. (1985) Promoting functional plasticity in the damaged nervous system. Science 227, 1544-1552.

Freeman, L. W., MacDongall, J., Turbes, C. C. and Bowman, D. E. (1960) The treatment of experimental lesions of the spinal cord of dogs with trypsin. J. Neurosurg. 17, 259-265.

Friede, R. L. and Samorajski, T. (1968) Myelin formation in the sciatic nerve of the rat. A quantitative electron microscopic histochemical and radioactive study. J. Neuropathol. Exp. Neurol. 27, 546-571.

Frisén, J., Fried, K., Sjögren, A. M. and Risling, M. (1993) Growth of ascending spinal axons in CNS scar tissue. Int. $J$. Dev. Neurosci. 4, 461-475.

Frisén, J., Haegerstrand, A., Risling, M., Fried, K., Johansson, C. B., Hammarberg, H., Elde, R., Hökfelt, T. and Cullheim, S. (1995) Spinal axons in central nervous system scar tissue are closely related to laminin-immunoreactive astrocytes. Neuroscience 65, 293-304.

Frotscher, M., Heimrich, B. and Deller, T. (1997) Sprouting in the hippocampus is layer-specific. TINS 20, 218-223.

Friedman, W. J., Ibanez, C. F., Hallbook, F., Persson, H., Cain, L. D., Dreyfus, C. F. and Black, I. B. (1993) Differential actions of neurotrophins in the locus coeruleus and basal forebrain. Exp. Neurol. 119, 72-78.

Gallo, V. and Bertolotto, A. (1990) Extracellular matrix of cultured glial cells, selective expression of chondroitin 4-sulfate by type-2 astrocytes and their progenitors. Exp. Cell Res. 187, 211223 .

Garcia-Abreu, J., Silva, L. C. F. Tovar, F. F., Onofre, G. R., Cavalcante, L. A. and Moura Neto, V. (1996) Compartmental distribution of sulfated glycosaminoglycans in lateral and medial midbrain astroglial cultures. Glia 17, 339-344.

Gaze, R. M. (1970) The Formation of Nerve Connections. Academic Press, London.

Gearhart, J. M., Oster-Granite, M. L. and Guth, L. (1979) Histological changes after transection of the spinal cord of fetal and neonatal mice. Exp. Neurol. 66, 1-15.

Gelderd, J. B. (1990) Evaluation of blood vessel and neurite growth into a collagen matrix placed within a surgically created gap in rat spinal cord. Brain Res. 511, 80-92.

Geschwind, M. D., Lu, B. and Fedoroff, H. J. (1994) Viral transfection of intrinsic cells within the brain. Expression of neurotrophic genes from HSV-1 vectors, modifying neuronal phenotype. In: Providing Pharmacological Access to the Brain, pp. 462-482. Ed. P. Conn. Academic Press, New York.

Giftochristos, N. and David, S. (1988) Laminin and heparan sulfate proteoglycan in the lesioned adult mammalian central nervous system and their possible relationship to axonal sprouting. J. Neurocytol. 17, 385-397.

Giulian, D. (1993) Reactive glia as rivals in regulating neuronal survival. Glia 7, 102-110.

Giulian, D., Chen, J., Ingeman, J. E., George, J. K. and Noponen, M. (1989) The role of mononuclear phagocytes in wound healing after traumatic injury to adult mammalian brain. $J$. Neurosci. 9, 4416-4429.

Giulian, D., Corpuz, M., Chapman, S., Mansouri, M. and Robertson, C. (1993) Reactive mononuclear phagocytes release neurotoxins after ischemic and traumatic injury to the central nervous system. J. Neurosci. Res. 3, 681-693.

Goldberg, W. J. and Bernstein, J. J. (1988) Fetal cortical astrocytes migrate from cortical homografts throughout the host brain and over the glia limitans. J. Neurosci. Res. 20, 38-45.

Goldsmith, H. S. and de la Torre, J. C. (1992) Axonal regeneration after spinal cord transection and reconstruction. Brain Res. 589, 217-224.

Goodman, C. S. (1996) Mechanisms and molecules that control growth cone guidance. Annu. Rev. Neurosci. 19, 341-377.

Goodman, M. N., Silver, J. and Jacobberger, J. W. (1993) Establishment and neurite outgrowth properties of neonatal and adult rat olfactory bulb glial cell lines. Brain Res. 13, 199-213.

Götz, B., Scholze, A., Clement, A., Joester, A., Schütte, K., Wigger, F., Frank, R., Spiess, E., Ekblom, P., and Faissner, A. (1994) Tenascin-C contains distinct adhesive, anti-adhesive and neurite outgrowth promoting sites for neurons. J. Cell. Biol. 126, 783-799.

Gouin, A., Bloch-Gallego, E., Tanaka, H., Rosenthal, A. and Henderson, C. E. (1996) Transforming growth factor-beta 3, glial cell line-derived neurotrophic factor, and fibroblast growth factor-2, act in different manners to promote motoneuron survival in vitro. J. Neurosci. Res. 43, 454-464.

Grill, R., Murai, K., Gage, F. H. and Tuszynski, M. H. (1997) Cellular delivery of neurotrophin-3 promotes corticospinal axonal growth and partial functional recovery after spinal cord injury. J. Neurosci. 15, 5560-5572.

Grothe, C. and Wewetzer, K. (1996) Fibroblast growth factor and its implications for developing and regenerating neurons. Int. J. Dev. Biol. 40, 403-410.

Groves, A. K., Entwistle, A., Jat, P. S. and Noble, M. (1993) The characterization of astrocyte cell lines that display properties of glial scar tissue. Dev. Biol. 159, 87-104.

Guénard, V., Morrissey, T. K., Kleitman, N., Bunge, R. P. and Aebischer, P. (1991) Cultured syngeneic adult Schwann cells seeded in synthetic guidance channels enhance sciatic and optic nerve regeneration. Soc. Neurosci. Abstr. 17, 565.

Guénard, V., Xu, X. M. and Bunge, M. B. (1993) The use of Schwann cell transplantation to foster central nervous system repair. Sem. Neurosci. 5, 401-411.

Guest, D., Rao, A., Olsen, L., Bunge, M. B. and Bunge, R. P. (1997) The ability of human Schwann cell grafts to promote regeneration in the transected nude rat spinal cord. Exp. Neurol. 148, 502-522.

Guth, L., Albuquerque, E. X., Deshpande, S. S., Barrett, C. P. Donati, E. J. and Warnick, J. E. (1980) Ineffectiveness of enzyme therapy on regeneration in the transected spinal cord of the rat. J. Neurosurg. 52, 73-86.

Hagg, T. and Varon, S. (1993) Neurotropism of nerve growth factor for adult rat septal cholinergic axons in vivo. Exp. Neurol. 119, 37-45.

Hagg, T., Muir, D., Engvall, E., Varon, S. and Manthorpe, M. (1989) Laminin-like antigen in rat CNS neurons, distribution and changes upon brain injury and nerve growth factor treatment. Neuron 3, 721-732.

Hall, E. D. (1989) Free radicals and CNS injury. Crit. Care. Clin. 5, 793-805.

Hanemann, C. O., Rosenbaum, C., Kupfer, S., Wosch, S., Stoegbauer, F. and Müller, H. W. (1998) Improved culture methods to expand Schwann cells with altered growth behaviour from CMT1A patients. Glia 23, 89-98.

Hardingham, T. E. and Fosang, A. J. (1992) Proteoglycans, many forms and many functions. FASEB. J. 6, 861-870.

Harvey, A. R., Chen, M. and Dyson, S. E. (1991) Glia cells transplanted to the rat optic tract. Influence on the regrowth of retinal axons. Ann. N.Y. Acad. Sci. U.S.A. 633, 573-576.

Harvey, A. R., Chen, M., Plant, G. W. and Dyson, S. E. (1994) Regrowth of axons within Schwann cell-filled polycarbonate tubes implanted into the damaged optic tract and cerebral cortex of rats. Rest. Neurol. Neurosci. 6, 221-237.

Harvey, A. R., Plant, G. W. and Tan, M. M. L. (1995) Schwann cells and the regrowth of axons in the mammalian CNS, review of transplantation studies in the rat visual system. Clin. exp. Pharmacol. Physiol. 22, 569-579.

Haskell, B. E., Stach, R. W., Werrbach-Perez, K. and Perez-Polo, J. R. (1987) Effect of retinoic acid on nerve growth factor receptors. Cell. Tiss. Res. 247, 67-73.

Hatten, M. E., Liem, R. K. H., Shelanski, M. L. and Mason, C. A. (1991) Astroglia in CNS injury. Glia 4, 233-243.

Hayes, R., Yang, K., Raghupathi, R. and McIntosh, T. K. (1995) Changes in gene expression follwoing traumatic brain injury in the rat. J. Neurotrauma 12, 779-790.

Hefti, F. (1986) Nerve growth factor promotes survival of septal cholinergic neurons after fimbrial transections. J. Neurosci. 6, 2155-2162.

Hefti, F., Hartikka, J. and Bolger, M. B. (1986) Effect of thyroid hormone analogs on the activity of choline acetyltransferase in cultures of dissociated septal cells. Brain Res. 375, 413-416.

Herdegen, T., Skene, P. and Bähr, M. (1997) The c-jun transcription factor-bipotential mediator of neuronal death, survival and regeneration. TINS 20, 227-231.

Hermanns, S., Wunderlich, G., Rosenbaum, C., Hanemann, C. O, Müller, H. W. and Stichel, C. C. (1997) Lack of immune responses to immediate or delayed implanted allogeneic and xenogeneic Schwann cell suspensions. Glia 21, 299-314.

Hermens, W. T. J. M. C., Giger, R. J., Holtmaat, A. J. G. D. Dijkhuizen, P. A., Houweling, D. and Verhaagen, J. (1997) Transient gene transfer to neurons and glia, analysis of adenoviral vector performance in the CNS and PNS. J. Neurosci. Meth. 71, 85-89.

Hill, S. J., Barbarese, E. and McIntosh, T. K. (1996) Regional heterogeneity in the response of astrocytes following traumatic 
brain injury in the adult rat. J. Neuropath. Exp. Neurol. 55, 1221-1229.

Hilton, G. (1994) Secondary brain injury and the role of neuroprotective agents. J. Neurosci. Nurs. 26, 251-255.

Hinkle, L., McCaig, C. D. and Robinson, K. R. (1981) The direction of growth of differentiating neurones and myoblasts from frog embryos in an applied electric field. J. Physiol. 314, 121135 .

Hodgson, C. P. (1995) The vector void in gene therapy. Can viral vectors and transfection be combined to permit safe, efficacious and targeted gene therapy? BioTechn. 13, 222-225.

Hoffman, D., Breakefield, X. O., Short, M. P. and Aebischer, P. (1993) Transplantation of polymer-encapsulated cell line genetically engineered to release NGF. Exp. Neurol. 122, 100-106.

Holt, C. E. and Harris, W. A. (1993) Position, guidance, and mapping in the developing visual system. J. Neurobiol. 24, 14001422

Holtmaat, A. J. G. D., Hermens, W. T. J. M. C., Oestreicher, A. B., Gispen, W.-H., Kaplitt, M. G. and Verhaagen, J. (1996) Efficient adenoviral ector-directed expression of a foreign gene to neurons and sustentacular cells in the mouse olfactory neuroepithelium. Mol. Brain Res. 41, 148-156.

Holtmaat, A. J. G. D., Hermens, W. T. J. M. C., Sonnemans, M. A. F., Giger, R. J., Van Leeuwen, F. W., Kaplitt, M. G., Oestreicher, A. B., Gispen, W.-H. and Verhaagen, J. (1997) Adenoviral vector-mediated expression of B-50/GAP-43 induces alterations in the membrane organization of olfactory axon terminals in vivo. J. Neurosci. 17, 6575-6586.

Holtzman, D. M., Kilbrige, J., Li, Y., Cunningham, E. T., Jr, Lenn, N. J., Clary, D. O., Reichardt, L. F. and Mobley, W. C. (1995) TrkA expression in the CNS: evidence for the existence of several novel NGF-responsive CNS neurons. J. Neurosci. 15, $1567-1576$.

Honkaniemi, J., Sagar, S. M., Pyykonen, I., Hicks, K. J. and Sharp, F. R. (1995) Focal brain injury induces multiple immediate early genes encoding zinc finger transcription factors. Mol. Brain Res. 28, 157-163.

Honmou, O., Felts, P. A., Waxman, S. G. and Kocsis, J. D. (1996) Restoration of normal conduction properties in demyelinated spinal cord axons in the adult rat by transplantation of exogenous Schwann cells. J. Neurosci. 16, 3199-3208.

Horvat, J. C. (1992) Neural transplants in spinal cord injury. Paraplegia 30, 23-26.

Houle, J. D. (1991) Demonstration of the potential for chronically injured neurons to regenerate axons into intraspinal peripheral nerve grafts. Exp. Neurol. 113, 1-9.

Houle, J. D. and Ziegler, M. K. (1994) Bridging a complete transection lesion of adult rat spinal cord with growth factor-teated nitrocellulose implants. J. Neural. Transpl. Plast. 5, 115-124.

Huber, L. J. and Chao, M. V. (1995) Mesenchymal and neuronal cell expression of the p75 neurotrophin receptor gene occur by different mechanisms. Dev. Biol. 167, 227-238.

Hüll, M. and Bähr, M. (1994) Regulation of immediate-early gene expression in rat retinal ganglion cells after axotomy and during regeneration through a peripheral nerve graft. J. Neurobiol. 25, $92-105$.

Hyman, C., Hofer, M., Barde, Y. A., Juhasz, M., Yancopoulos, G. D., Squinto, S. P. and Lindsay, R. M. (1991) BDNF is a neurotrophic factor for dopaminergic neurons of the substantia nigra. Nature 350, 230-232.

Hyman, C., Juhasz, M., Jackson, C., Wright, P., Ip, N. Y. and Lindsay, R. M. (1994) Overlapping and distinct actions of the neurotrophins BDNF, NT-3, and NT-4/5 on cultured dopaminergic and GABAergic neurons of the ventral mesencephalon. $J$. Neurosci. 14, 335-347.

Hynes, M. A., Poulsen, K., Armanini, M., Berkemeier, L., Phillips, H. and Roenthal, A. (1994) Neurotrophin- $4 / 5$ is a survival factor for embryonic midbrain dopaminergic neurons enriched cultures. J. Neurosci. Res. 37, 144-154.

Iozzo, R. V. (1997) The family of the small leucine-rich proteoglycans, key regulators of matrix assembly and cellular growth. Crit. Rev. Biochem. Mol. Biol. 32, 141-174.

Ip, N. Y., Yancopoulos, G. D. and Lindsay, R. M. (1993a) Cultured hippocampal neurons show responses to BDNF, NT3, and NT-4, but not NGF. J. Neurosci. 13, 3394-3405.

Ip, N. Y., Wiegand, S. J., Morse, J. and Rudge, J. S. (1993b) Injury-induced regulation of ciliary neurotrophic factor mRNA in the adult rat brain. Eur. J. Neurosci. 5, 25-33.

Isacson, O. and Deacon, T. (1997) Neural transplantation studies reveal the brain's capacity for continuous reconstruction. TINS 20, 477-482.
Isacson, O., Deacon, T. W., Pakzaban, P., Galpern, W. R., Dinsmore, J. and Burns, L. H. (1995) Transplanted xenogeneic neural cells in neurodegenerative disease models exhibit remarkable axonal target specificity and distinct growth patterns of glial and axonal fibers. Nature Med. 1, 1189-1194.

Isono, M., Geller, H. M., Poltorak, M. and Freed, W. J. (1992) Intracerebral transplantation of the A7 immortalized astrocytic cell line. Rest. Neurol. Neurosci. 4, 301-309.

Iwashita, Y., Kawaguchi, S. and Murata, M. (1994) Restoration of function by replacement of spinal cord segments in the rat. Nature 367, 167-170.

Jaeger, C. B. and Blight, A. R. (1997) Spinal compression injury in guinea pigs, structural changes of endothelium and its perivascular cell associations after blood-brain barrier breakdown and repair. Exp. Neurol. 144, 381-399.

Jaffe, L. F. and Poo, M.-M. (1979) Neurites grow faster toward the cathode than the anode in a steady field. J. Exp. Zool. 209, $115-127$.

Jenkins, R., Tetzlaff, W. and Hunt, S. P. (1993) Differential expression of immediate early genes in rubrospinal neuron following axotomy in the rat. Eur. J. Neurosci. 5, 203-209.

Johnson-Green, P. C., Dow, K. E. and Riopelle, R. J. (1992) Neurite growth modulation associated with astrocyte proteoglycans, influence of activators of inflammation. Glia 5, 33-42.

Joosten, E. A. J., Bär, P. R. and Gispen, W. H. (1995) Collagen implants and cortico-spinal axonal growth after mid-thoracic spinal cord lesion in the adult rat. J. Neurosci. Res. 41, 481490.

Junger, H. and Varon, S. (1997) Neurotrophin-4 (NT-4) and glial cell line-derived neurotrophic factor (GDNF) promote the survival of corticospinal motor neurons of neonatal rats in vitro. Brain Res. 762, 56-60.

Kalderon, N. and Fuks, Z. (1996a) Structural recovery in lesioned adult mammalian spinal cord by X-irradiation of the lesion site. Proc. Natl Acad. Sci. U.S.A. 93, 11179-11184.

Kalderon, N. and Fuks, Z. (1996b) Severed corticospinal axons recover electrophysiologic control of muscle activity after X-ray therapy in lesioned adult spinal cord. Proc. Natl Acad. Sci. U.S.A. 93, 11185-11190.

Kalderon, N., Ahonen, K. and Fedoroff, S. (1990a) Developmental transition in plasticity properties of differentiating astrocytes, age related biochemical profile of plasminogen activators in astroglial cultures. Glia 3, 413-426.

Kalderon, N., Alfieri, A. A. and Fuks, Z. (1990b) Beneficial effects of X-irradiation on recovery of lesioned mammalian central nervous tissue. Proc. Natl Acad. Sci. U.S.A. 87, 10058-10062.

Kapfhammer, J. P. and Schwab, M. E. (1994) Inverse patterns of myelination and GAP-43 expression in the adult CNS, neurite growth inhibitors as regulators of neuronal plasticity? J. Comp. Neurol. 340, 194-206.

Kaplitt, M. G., Leone, P., Samulski, R. J., Xiao, X., Pfaff, D. W., O'Malley, K. L. and During, M. J. (1994) Long-term gene expression and phenotypic correction using adeno-associated virus vectors in the mammalian brain. Nature Genetics 8, 148-154.

Kater, S. B. and Lipton, S. A. (1995) Neurotransmitter regulation of neuronal outgrowth, plasticity and survival in the year 2001. TINS 18, 71-72

Kater, S. B. and Mills, L. R. (1991) Regulation of growth cone behavior by calcium. J. Neurosci. 11, 891-899.

Kater, S. B., Mattson, M. P., Cohan, C. and Connor, J. (1988) Calcium regulation of the neuronal growth cone. TINS 11, 315 321.

Katoh-Semba, R., Matsuda, M., Kato, K. and Oohira, A. (1995) Chondroitin sulphate proteoglycans in the rat brain, candidates for axon barriers of sensory neurons and the possible modification by laminin of their actions. Eur. J. Neurosci. 7, 613-621.

Keirstead, S. A., Rasminsky, M., Fukuda, Y., Carter, D. A., Aguayo, A. J. and Vidal-Sanz, M. (1989) Electrophysiological responses in hamster superior colliculus evoked by regenerating retinal axons. Science 246, 255-258.

Keirstead, H. S., Hasan, S. J., Muir, G. D and Steeves, J. D. (1992) Suppression of the onset of myelination extends the permissive period for the functional repair of embryonic spinal cord. Proc. Natl Acad. Sci. U.S.A. 89, 11664-11668.

Keynes, R. and Cook, G. M. W. (1995) Axon guidance molecules. Cell 83, 161-169.

Khan, T., Dauzvardis, M. and Sayers, S. (1991) Carbon filament implants promote axonal growth across transected rat spinal cord. Brain Res. 541, 139-145.

Kiernan, J. A. (1979) Hypothesis concerned with axonal regeneration in the mammalian nervous system. Biol. Rev. 54, 155-197. 
Kjellén, L. and Lindahl, U. (1991) Proteoglycans, structures and interactions. Annu. Rev. Biochem. 60, 443-475.

Kliot, M., Smith, G. M., Siegal, J. D. and Silver, J. (1990) Astrocyte-polymer implants promote regeneration of dorsal root fibers into the adult mammalian spinal cord. Exp. Neurol 109, 57-69.

Knusel, B. and Hefti, F. (1991) K-252b is a selective and nontoxic inhibitor of nerve growth factor action on cultured brain neurons. J. Neurochem. 57, 955-962.

Koizumi, S., Contreras, M. L. and Matsuda, Y. (1988) K-252a, A specific inhibitor of the action of nerve growth factor on $\mathrm{PC12}$ cells. J. Neurosci. 8, 715-721.

Koliatsos, V. E., Price, D. L., Gouras, G. K., Cayouette, M. H., Burton, L. E. and Winslow, J. W. (1994) Highly selective effects of nerve growth factor, brain-derived neurotrophic factor, and neurotrophin-3 on intact and injured basal forebrain magnocellular neurons. J. Comp. Neurol. 343, 247-262.

Kononen, J., Soinila, S., Persson, H., Honkaniemi, J., Hokfelt, T. and Pelto-Huikko, M. (1994) Neurotrophins and their receptors in the rat pituitary gland, regulation of BDNF and trkB mRNA levels by adrenal hormones. Mol. Brain Res. 27, 347-354.

Kresse, H., Hausser, H., Schönherr, E. and Bittner, G. D. (1994) Biosynthesis and interactions of small chondroitin/dermatan sulphate proteoglycans. Eur. J. Clin. Chem. Clin. Biochem. 32, 259-264.

Kroemer, G. (1997) The proto-oncogene Bcl-2 and its role in regulating apoptosis. Nature Med. 3, 614-620.

Kromer, L. F. and Cornbrooks, C. J. (1985) Transplants of Schwann cell cultures promote axonal regeneration in the adult mammalian brain. Proc. Natl Acad. Sci. U.S.A. 82, 6330-6334.

Kromer, L. F., Björklund, A. and Stenevi, U. (1981) Regeneration of the septohippocampal pathways in adult rats is promoted by utilizing embryonic hippocampal implants as bridges. Brain Res. 210, 173-200

Kuffler, D. P. (1996) Chemoattraction of sensory neuron growth cones by diffusible concentration gradients of acetylcholine. Mol. Chem. Neuropathol. 28, 199-208.

Kuffler, D. P. and Luethi, T. (1993) Identification of molecules in a muscle extracellular matirx extract that promotes process outgrowth from cultured adult frog motoneurons. J. Neurobiol. 24, $515-527$.

Kuhn, T. B., Schmidt, M. F. and Kater, S. B. (1995) Laminin and fibronectin guideposts signal sustained but opposite effects to passing growth cones. Neuron 14, 275-285.

Kupsch, A., Oertel, W. H., Earl, C. D. and Sautter, J. (1995) Neuronal transplantation and neurotrophic factors in the treatment of Parkinson's disease-update February 1995. J. Neural. Transm. 46, 193-207.

Landis, D. M. D. (1994) The early reactions of non-neuronal cells to brain injury. Annu. Rev. Neurosci. 17, 133-151.

Lang, D. M., Rubin, B. P., Schwab, M. E. and Stürmer, C. A. O. (1995) CNS myelin and oligodendrocytes of the Xenopus spinal cord-but not optic nerve-are nonpermissive for axon growth. J. Neurosci. 15, 99-109.

Lapchak, P. A., Araujo, D. M., Carswell, S. and Hefti, F. (1993) Distribution of [125I] nerve growth factor in the rat brain following a single intraventricular injection, correlation with the topographical distribution of trkA messenger RNA-expressing cells. Neuroscience 54, 445-460.

Laywell, E., Dörries, U., Bartsch, U., Faissner, A., Schachner, M. and Steindler, D. A. (1992) Enhanced expression of the developmentally regulated extracellular matrix molecule tenascin following adult brain injury. Proc. Natl Acad. Sci. U.S.A. 89, 2634 2639

Lazarov-Spiegler, O., Solomon, A. S., Zeev-Brann, A. B., Hirschberg, D. L., Lavie, V. and Schwartz, M. (1996) Transplantation of activated macrophages overcomes central nervous system regrowth failure. FASEB J. 10, 1296-1302.

Le Gal La Salle, G., Robert, J.-L., Berrard, S., Ridoux, V., Stratford-Perricaudet, L. D., Perricaudet, M. and Mallet, J. (1993) An adenovirus vector for gene transfer into neurons and glia in the brain. Science 259, 988-990.

Lee, S. C., Moore, G. R. W., Golenwsky, G. and Raine, C. S. (1990) Multiple sclerosis, a role for astroglia in active demyelination suggested by class II MHC expression and ultrastructural study. J. Neuropath. Exp. Neurol. 49, 122-136.

Lessmann, V., Gottmann, K. and Heumann, R. (1994) BDNF and NT-4/5 enhance glutamatergic synaptic transmission in cultured hippocampal neurones. Neuroreport 6, 21-25.

Levi, A. D. O., Guénard, V., Aebischer, P. and Bunge, R. P. (1994) The functional characteristics of Schwann cells cultured from human peripheral nerve after transplantation into a gap within the sciatic nerve. J. Neurosci. 14, 1309-1319.

Levi-Montalcini, R. (1987) The nerve growth factor. Thirty-five years later. EMBO J. 6, 1145-1154

Levine, J. M. (1996) Increased expression of the NG2 chondroitin sulfate proteoglycan after brain injury. J. Neurosci. 14, 47164730

Levy, W. J., Humphrey, M. F. and Dietrich, D. (1988) A comparison of saline and matrigel as substrates for peripheral nerve regeneration in an in vivo window chamber. Soc. Neurosci. Abstr. 14, 499 .

Lewin, G. R. and Barde, Y. A. (1996) Physiology of the neurotrophins. Annu. Rev. Neurosci. 19, 289-317.

Li, D., Field, P. M. and Raisman, G. (1995) Failure of axon regeneration in postnatal rat entorhinal-hippocampal slice coculture is due to maturation of the axon, not that of the pathway or target. Eur. J. Neurosci. 7, 1164-1171.

Li, M., Shibata, A., Li, C., Braun, P. E., McKerracher, L., Roder, J., Kater, S. B. and David, S. (1996) Myelin-associated glycoprotein inhibits neurite/axon growth and causes growth cone collapse. J. Neurosci. Res. 46, 404-414.

Li, M. S. and David, S. (1996) Topical glucocorticoids modulate the lesion interface after cerebral cortical stab wounds in adult ats. Glia 18, 306-318.

Li, W. W. Y., Yew, D. T. W., Chuah, M. I., Leung, P. C. and Tsang, D. S. C. (1994) Axonal sprouting in the hemisected adult rat spinal cord. Neuroscience 61, 133-139.

Li, Y. and Raisman, G. (1994) Schwann cells induce sprouting in motor and sensory axons in the adult rat spinal cord. $J$. Neurosci. 14, 4050-4063.

Li, Y. and Raisman, G. (1995) Sprouts from cut corticospina axons persist in the presence of astrocytic scarring in long-term lesions of the adult rat spinal cord. Exp. Neurol. 134, 102-111.

Li, Y. and Raisman, G. (1997) Integration of transplanted cultured Schwann cells into the long myelinated fiber tracts of the adult spinal cord. Exp. Neurol. 145, 397-411.

Li, Y., Filed, P. M. and Raisman, G. (1997) Repair of adult rat corticospinal tract by transplants of olfactory ensheathing cells. Science 277, 2000-2002.

Liesi, P. (1985) Laminin-immunoreactive glia distinguish regenerative adult CNS systems from non-regenerative ones. EMBO J. 4, 2505-2511.

Liesi, P., Kaakkola, S., Dahl, D. and Vaheri, A. (1984) Laminin is induced in astrocytes of adult brain by injury. EMBO J. 3, 683686.

Lin, Q., Cunningham, L. A., Estein, L. G., Pechan, P. A., Short, M. P., Fleet, C. and Bohn, M. C. (1997) Human fetal astrocytes as an ex vivo gene therapy vehicle for delivering biologically active nerve growth factor. Hum. Gene. Ther. 8, 331-339.

Lindholm, D., Hengerer, B. and Heumann, R. (1990) Glucocorticoid hormones negatively regulate nerve growth factor expression in vivo and in cultured rat fibroblasts. Eur. J. Neurosci. 2, 795-801.

Lindholm, D., Harikka, J., da Penha Berzaghi, M., Castren, E. Tzimagiorgis, G., Hughes, R. A. and Thoenen, H. (1994) Fibroblast growth factor-5 promotes differentiation of cultured rat septal cholinergic and raphe serotonergic neurons: comparison with the effects of neurotrophins. Eur. J. Neurosci. 6, 244 252

Lindsay, R. M. (1986) Reactive gliosis. In: Astrocytes, pp. 231262. Eds. S. Fedoroff and A. Vernadakis. Academic Press, Orlando, FL.

Lindsay, R. M. (1988) Nerve growth factors (NGF, BDNF) enhance axonal regeneration but are not required for survival of adult sensory neurons. J. Neurosci. 8, 2394-2405.

Lindvall, O. (1991) Prospects of transplantation in human neurodegenerative disease. TINS 14, 376-384.

Lindvall, O., Ernfors, P., Bengzon, J., Kokaia, Z., Smith, M. L. S K. and Persson, H. (1992) Differential regulation of mRNA for nerve growth factor, brain-derived neurotrophic factor, and neurotrophin 3 in the adult rat brain following cerebral ischemia and hypoglycemic coma. Proc. Natl Acad. Sci. U.S.A. 89, 648-652.

Lips, K. Stichel, C. C. and Müller, H. W. (1995) Restricted appearance of tenascin and chondroitin sulfate proteoglycan after transection and sprouting of adult rat postcommissural fornix. J. Neurocytol. 24, 449-464.

Lipton, S. A., Wagner, J. A., Madison, R. D. and D'Amore, P. A. (1988) Acidic fibroblast growth factor enhances regeneration of processes by postnatal mammalian retinal ganglion cells in culture. Proc. Natl Acad. Sci. U.S.A. 85, 2388-2392. 
Lochter, A., Vaughan, L., Kaplony, A., Prochiantz, A., Schachner, M. and Faissner, A. (1991) J1/tenascin in substratebound and soluble form displays contrary effects on neurite outgrowth. J. Cell. Biol 113, 1159-1171.

Logan, A., Frautschy, S. A., Gonzalez, A.-M. and Baird, A. (1992) A time course for the focal elevation of synthesis of basic fibroblast growth factor and one of its high-affinity receptors (flg) following a localized cortical brain injury. J. Neurosci. 12, 3828-3837.

Logan, A., Berry, M., Gonzalez, A. M., Frautschy, S. A., Spron, M. B. and Baird, A. (1994) Effects of transforming growth factor $\beta 1$ on scar production in the injured central nervous system of the rat. Eur. J. Neurosci. 6, 355-363.

Lucidi-Phillipi, C. A., Gage, F. H., Shults, C. W., Jones, K. R., Reichardt, L. F. and Kang, U. J. (1995) Brain-derived neurotrophic factor-transduced fibroblasts, production of BDNF and effects of grafting to the adult rat brain. J. Comp. Neurol. 354, 361-376.

Lundberg, C., Horello, P., Mallet, J. and Björklund, A. (1996) Generation of DOPA-producing astrocytes by retroviral transduction of the human tyrosine hydroxylase gene, in vitro characterization and in vivo effects in the rat Parkinson model. Exp. Neurol. 139, 39-53.

Lustgarten, J. H., Proctor, M., Haroun, R. I., Avellino, M., Pindzola, A. A. and Kliot, M. (1991) Semipermeable polymer tubes provide a microenvironment for in vivo analysis of dorsal root regeneration. J. Biochem. Engl. 113, 184-188.

Maisonpierre, P. C., Belluscio, L., Squinto, S., Ip, N. Y., Furth, M. E., Lindsay, R. M. and Yancopoulos, G. D. (1990) Neurotrophin-3: a neurotrophic factor related to NGF and BDNF. Science 247, 1446-1451.

Mallat, M., Houlgatte, R., Brachet, P. and Prochiantz, A. (1989) Lipopolysaccharide-stimulated rat brain macrophages release NGF in vitro. Dev. Biol. 113, 309-311.

Mansour-Robaey, S., Clarke, D. B., Wang, Y. C., Bray, G. M. and Aguayo, A. J. (1994) Effects of ocular injury and administration of brain-derived neurotrophic factor on survival and regrowth of axotomized retinal ganglion cells. Proc. Natl Acad. Sci. U.S.A. 91, 1632-1636.

Marchand, R. and Woerly, S. (1990) Transsected spinal cords grafted with in-situ self assembled collagen matrices. Neuroscience 36, 45-60.

Margolis, R. U. and Margolis, R. K. (1989) Nervous tissue proteoglycans. Dev. Neurosci. 11, 276-288.

Marsh, G. and Beams, H. W. (1946) In vitro control of growing chick nerve fibers by applied electric currents. J. Cell. Comp. Physiol. 27, 139-157.

Martin, D., Schoenen, J., Delrée, P., Leprince, P., Rogister, B. and Moonen, G. (1991) Grafts of syngeneic cultured, adult dorsal root ganglion-derived Schwann cells to the injured spinal cord of adult rats, preliminary morphological studies. Neurosci. Lett. 124, $44-48$.

Martin, D. L. (1992) Synthesis and release of neuroactive substances by glial cells. Glia $\mathbf{5}, 81-94$.

Martini, R. (1994) Expression and functional roles of neural cell surface molecules and extracellular matrix components during development and regeneration of peripheral nerves. $J$. Neurocytol. 23, 1-28.

Martini, R., Schachner, M. and Faissner, A. (1990) Enhanced expression of the extracellular matrix molecule $\mathrm{J} 1 /$ tenascin in the regenerating adult mouse sciatic nerve. J. Neurocytol. 19, 601616.

Marton, L. S., Gulcher, J. R. and Stefansson, K. (1989) Binding of hexabrachions to heparin and DNA. J. Biol. Chem. 264, 13145-13149.

Matsumoto, Y., Ohmori, K. and Fujiwara, M. (1992) Microglial and astroglial reactions to inflammatory lesions of experimental autoimmune encephalomyelitis in the rat central nervous system. J. Neuroimmunol. 37, 23-33.

Maxwell, W. L., Duance, V. C., Lehto, M., Ashhurst, D. E. and Berry, M. (1984) The distribution of types I, III, IV and V collagens in penetrant lesions of the central nervous system of the rat. Histochem. J. 16, 1219-1229.

Maxwell, W. L., Follows, R., Ashhurst, D. E. and Berry, M. (1990a) The response of the cerebral hemisphere of the rat to injury. I. The mature rat. Phil. Trans. R. Soc. Lond. B. 328, 36500

Maxwell, W. L., Follows, R., Ashhurst, D. E. and Berry, M. (1990b) The response of the cerebral hemisphere of the rat to injury. II. The neonatal rat. Phil. Trans. R. Soc. Lond. B. 32, $501-513$
McCaig, C. D. (1986) Dynamic aspects of amphibian neurite growth and the effects of an applied electric field. J. Physiol. 375, 55-69.

McCaig, C. D. (1987) Spinal neurite reabsorption and regrowth in vitro depend on the polarity of an applied electric field Development 100, 1-41

McCaig, C. D. (1990a) Nerve growth in a small applied electric field and the effects of pharmacological agents on rate and orientation. J. Cell. Sci. 95, 617-622.

McCaig, C. D. (1990b) Nerve branching is induced and oriented by a small applied electric field. J. Cell. Sci. 95, 605-615.

McFarlane, S. and Holt, C. E. (1997) Growth factors: a role in guiding axons. Trends Cell Biol, 7, 424-430.

McIntosh, T. K. (1994) Neurochemical sequelae of traumatic brain injury, therapeutic implications. Cerebrovasc. Brain Metabol. Rev. 6, 109-162.

McKeon, R. J., Schreiber, R. C., Rudge, J. S. and Silver, J. (1991) Reduction of neurite outgrowth in a model of glial scarring following CNS injury is correlated with the expression of inhibitory molecules on reactive astrocytes. J. Neurosci. 11, 33983411 .

McKeon, R. J., Höke, A. and Silver, J. (1995) Injury-induced proteoglycans inhibit the potential for laminin-mediated axon growth on astrocytic scars. Exp. Neurol. 136, 32-43.

McKerracher, L., David, S., Jackson, D. L., Kottis, V., Dunn, R. J. and Braun, P. E. (1994) Identification of myelin-associated glycoprotein as a major myelin-derived inhibitor of neurite growth. Neuron 13, 805-811.

McMahon, S. B. and Kett-White, R. (1991) Sprouting of peripherally regenerating primary sensory neurons in the adult centra nervous system. J. Comp. Neurol. 304, 307-315.

Menei, P., Montero-Menei, C. N., Whittemore, S. R., Bunge, R. P. and Bunge, M. B. (1998) Schwann cells genetically modified to secrete human BDNF promote enhanced axonal regrowth across transected adult rat spinal cord. Eur. J. Neurosci. 10, 607-621.

Miklossy, J. and Van der Loos, H. (1991) The long-distance effects of brain lesions, visualization of myelinated pathways in the human brain using polarizing and fluorescence microscopy. $J$. Neuropathol. Exp. Neurol. 50, 1-15.

Milligan, C. E., Levitt, P. and Cunningham, T. J. (1991) Brain macrophages and microglia respond differently to lesions of the developing and adult visual system. J. Comp. Neurol. 314, 136146.

Mitrovic, N., Dörries, U. and Schachner, M. (1994) Expression of the extracellular matrix glycoprotein tenascin in the somatosensory cortex of the mouse during postnatal development, an immunocytochemical and in situ hybridization analysis. $J$. Neurocytol. 23, 364-378.

Monschau, B., Kremoser, C., Ohta, K., Tanaka, H., Kaneko, T. Yamada, T., Handwerker, C., Hornberger, M. R., Loschinger, J., Pasquale, E. B., Siever, D. A., Verderame, M. F., Muller, B. K., Bonhoeffer, F. and Drescher, U. (1997) Shared and distinct functions of RAGS and ELF-1 in guiding retinal axons. EMBO J. 16, 1258-1267.

Montero-Menei, C. N., Pouplard-Barthelaix, A., Gumpel, M. and Baron-Van Evercooren, A. (1992) Pure Schwann cell suspension grafts promote regeneration of the lesioned septo-hippocampal cholinergic pathway. Brain Res. 570, 198-208.

Montgomery, C. T. and Robson, J. A. (1993) Implants of cultured Schwann cells support axonal growth in the central nervous system of adult rats. Exp. Neurol. 122, 107-124.

Montgomery, C. T., Tenaglia, E. A. and Robson, J. A. (1996) Axonal growth into tubes implanted within lesions in the spinal cords of adult rats. Exp. Neurol. 137, 277-290.

Moore, S. and Thanos, S. (1996) The concept of microglia in relation to central nervous system disease and regeneration. Prog. Neurobiol. 48, 441-460.

Morrissey, T. K., Bunge, R. P. and Kleitman, N. (1995) Human Schwann cells in vitro. I. Failure to differentiate and support neuronal health under coculture conditions that promote full function of rodent cells. J. Neurobiol. 28, 171-189.

Mukhopadhyay, G., Doherty, P., Walsh, F. S., Crocker, P. R. and Filbin, M. T. (1994) A novel role for myelin-associated glycoprotein as an inhibitor of axonal regeneration. Neuron 13, 757 767.

Müller, H. W. (1993) Adhesion Factors. In: Neurotrophic Factors, pp. 509-526. Eds. J. H. Fallon and S. E. Loughlin. Academic Press, San Diego, CA

Müller, H. W., Junghans, U. and Kappler, J. (1996) Astroglial neurotrophic and neurite-promoting factors. In: Chemical Factors in Neural Growth, Degeneration and Repair, Vol. 15, pp. 377-397. Ed. C. Bell. Elsevier Science, Amsterdam. 
Nagata, K., Takei, N., Nakajima, K., Saito, H. and Kohsaka, S. (1993) Microglial conditioned medium promotes survival and development of cultured mesencephalic neurons from embryonic rat brain. J. Neurosci. Res. 34, 357-363.

Nait Oumesmar, B., Vignais, L., Duhamel-Clerin, E., AvellanaAdalid, V., Rougon, G. and Baron-Van Evercooren, A. (1995) Expression of the highly polysialyated neural cell adhesion molecule during postnatal myelination and following chemically induced demyelination of the adult mouse spinal cord. Eur. J. Neurosci. 7, 480-491.

Nakahara, Y., Gage, F. H. and Tuszynski, M. H. (1996) Grafts of fibroblasts genetically modified to secrete NGF, BDNF, NT-3, or basic FGF elicit differential responses in the adult spinal cord. Cell. Transplantation 5, 191-204.

Nakamoto, M., Cheng, H. J., Friedman, G. C., McLaughlin, T., Hansen, M. J., Yoon, C. H., O'Leary, D. D. and Flanagan, J. C. (1996) Topographically specific effects of ELF-1 on retinal axon guidance in vitro and retinal axon mapping in vivo. Cell 86, 755-766.

Naldini, L., Blömer, U., Gallay, P., Ory, D., Mulligan, R., Gage, F. H., Verma, I. M. and Trono, D. (1996) In vivo gene delivery and stable transduction of nondividing cells by a lentiviral vector. Science 272, 263-267.

Nathan, C. F. (1987) Secretory products of macrophages. J. Clin. Invest. 79, 319-326.

Needels, D. L., Nieto-Sampedro, N. and Cotman, C. W. (1986) Induction of a neurite-promoting factor in rat brain following injury or deafferentation. Neuroscience 18, 517-526.

Neuberger, T. J., Cornbrooks, C. J. and Kromer, L. F. (1992) Effects of delayed transplantation of cultured Schwann cells on axonal regeneration from central nervous system cholinergic neurons. J. Comp. Neurol. 315, 16-33.

Neumann, H., Boncraut, J., Hahnel, C., Misgeld, T. and Wekerle, H. (1996) Neuronal control of MHC class II inducibility in rat astrocytes and microglia. Eur. J. Neurosci. 8, 2582-2590.

Nieto-Sampedro, N., Lewis, E. R., Cotman, C. W., Manthorpe, M., Skaper, S. D., Barbin, G., Longo, F. M. and Varon, S. (1982) Brain injury causes a time-dependent increase in neuronotrophic activity at the lesion site. Science 2217, 860-861.

Nieto-Sampedro, N., Manthorpe, M., Barbin, G., Varon, S. and Cotman, C. W. (1983) Injury-induced neuronotrophic activity in adult rat brain, correlation with survival of delayed implants in the wound cavity. J. Neurosci. 3, 2219-2229.

Nonomura, T., Kubo, T., Oka, T., Shimoke, K., Yamada, M., Enokido, Y. and Hatanaka, H. (1996) Signaling pathways and survival effects of BDNF and NT-3 on cultured cerebellar granule cells. Dev. Brain Res. 97, 42-50.

Norenberg, M. D. (1994) Astrocyte response to CNS injury. $J$. Neuropathol. Exp. Neurol. 53, 213-220.

Noske, W., Lentzen, H., Lange, K. and Keller, K. (1982) Phagocytic activity of glial cells in culture. Exp. Cell. Res. 142, 437-445.

Olanow, C. W., Kordower, J. H. and Freeman, T. B. (1996) Fetal nigral transplantation as a therapy for Parkinson's disease. TINS 19, 102-109.

Orida, N. and Poo, M.-M. (1978) Electrophoretic movement and localization of acetylcholine receptors in the embryonic muscle cell membrane. Nature $\mathbf{2 7 5}, 31-35$.

Oueda, M. and Hagg, T. (1996) Nerve growth factor promotes regeneration of sensory axons into the adult rat spinal cord. Exp. Neurol. 140, 218-229.

Paino, C. L. and Bunge, M. B. (1991) Induction of axon growth into Schwann cell implants grafted into lesioned adult rat spinal cord. Exp. Neurol. 114, 254-257.

Paino, C. L., Fernandez-Valle, C., Bates, M. L. and Bunge, M. B. (1994) Regrowth of axons in lesioned adult rat spinal cord, promotion by implants of cultured Schwann cells. J. Neurocytol. 23, 433-452.

Patel, N. and Poo, M. (1982) Orientation of neurite growth by extracellular electric fields. J. Neurosci. 2, 483-496.

Patterson, S. L., Grover, L. M., Schwartzkroin, P. A. and Bothwell, M. (1992) Neurotrophin expression in rat hippocampal slices: a stimulus paradigm inducing LTP in CA1 evokes increases in BDNF and NT-3 mRNAs. Neuron 9, 1081-1088.

Perry, V. H. and Gordon, S. (1988) Macrophages and microglia in the nervous system. TINS 11, 273-277.

Perry, V. H., Brown, M. C. and Gordon, S. (1987) The macrophage response to central and peripheral nerve injury. J. Exp. Med. 165, 1218-1223.

Perry, V. H., Andersson, P.-B. and Gordon, S. (1993) Macrophages and inflammation in the central nervous system. TINS 16, 268-273.
Phillips, L. L. and Turner, J. E. (1991) Biphasic cellular response to transection in the newt optic nerve, glial reactivity precedes axonal regeneration. J. Neurocytol. 20, 51-64.

Pindzola, R. R., Doller, C. and Silver, J. (1993) Putative inhibitory extracellular matrix molecules at the dorsal root entry zone of the spinal cord during development and after root and sciatic nerve lesions. Dev. Biol. 156, 34-48.

Pizzorusso, T., Fagiolini, M., Fabris, M., Ferrari, G. and Maffei, L. (1994) Schwann cells transplanted in the lateral ventricles prevent the functional and anatomical effects of monocular deprivation in the rat. Proc. Natl Acad. Sci. U.S.A. 91, 25722576

Plant, G. W., Harvey, A. R. and Chirila, T. V. (1995) Axonal growth within poly(2-hydroxyethyl methacrylate) sponges infiltrated with Schwann cells and implanted into the lesioned rat optic tract. Brain Res. 671, 119-130.

Poo, M.-M. and Robinson, K. R. (1977) Electrophoresis of concanavalin A receptors along embryonic muscle cell membrane. Nature 265, 602-605.

Povlishock, J. T. and Christman, C. W. (1995) The pathobiology of traumatically induced axonal injury in animals and humans, a review of current thoughts. J. Neurotrauma 12, 555-564.

Povlishock, J. T., Erb, D. E. and Astruc, J. (1992) Axonal response to traumatic brain injury, reactive axonal change, deafferentation, and neuroplasticity. J. Neurotrauma 9(Suppl. 1), S189-S200.

Powell, E. M., Sobarzo, M. R. and Saltzman, W. M. (1990) Controlled release of nerve growth factor from a polymeric implant. Brain Res. 515, 309-311.

Prewitt, C. M. F., Niesman, I. R., Kane, C. J. M. and Houle, J. D. (1997) Activated macrophage/microglial cells can promote the regeneration of sensory axons into the injured spinal cord. Exp. Neurol. 148, 433-443.

Puchala, E. and Windle, W. F. (1977) The possibility of structural and functional restitution after spinal cord injury: a review. Exp. Neurol. 55, 1-42.

Pundt, L. L., Kondoh, T., Conrad, J. A. and Low, W. C. (1996) Transplantation of human striatal tissue into a rodent model of Huntington's disease, phenotypic expression of transplanted neurons and host-to-graft innervation. Brain Res. Bull. 39, 23 32

Rabchevsky, A. G. and Streit, W. J. (1997) Grafting of cultured microglial cells into the lesioned spinal cord of adult rats enhances neurite outgrowth. J. Neurosci. Res. 47, 34-48.

Rabin, S. J. and Mocchetti, I. (1995) GM1 ganglioside activates the high-affinity nerve growth factor receptor trkA. $J$. Neurochem. 65, 347-354.

Raisman, G. and Field, P. M. (1973) A quantitative investigation of the development of collateral reinnervation after partial deafferentation of the septal nuclei. Brain Res. 50, 251-264.

Raisman, G., Lawrence, J. M. and Brook, G. A. (1993) Schwann cells transplanted into the CNS. Int. J. Dev. Neurosci. 11, 651669.

Ramon-Cuéto, A. and Nieto-Sampedro, N. (1992) Glial cells from rat olfactory bulb, immunocytochemical properties of pure cultures of ensheathing cells. Neuroscience 47, 213-220.

Ramon-Cuéto, A. and Nieto-Sampedro, N. (1994) Regeneration into the spinal cord of transected dorsal root axons is promoted by ensheathing glia transplants. Exp. Neurol. 127, 232-244.

Ramon-Cuéto, A., Perez, J. and Nieto-Sampedro, N. (1993) In vitro enfolding of olfactory neurites by $\mathrm{p} 75 \mathrm{NGF}$ receptor positive ensheathing cells from adult rat olfactory bulb. Eur. J. Neurosci. 5, 1172-1180.

Ramón y Cajal, S. (1928) Degeneration and Regeneration of the Nervous System. Hafner, New York.

Ray, J., Hogg, J., Beutler, A. S., Takayama, H., Baird, A. and Gage, F. H. (1995) Expression of biologically active basic fibroblast growth factor by genetically modified rat primary skin fibroblasts. J. Neurochem. 64, 503-513.

Reier, P. J. and Houle, J. D. (1988) The glial scar, its bearing on axonal elongation and transplantation approaches to CNS repair. In: Functional Recovery in Neurological Disease, pp. 87138. Ed. S. G. Waxmann. Raven Press, New York.

Reier, P. J., Stensaas, L. J. and Guth, L. (1983) The astrocytic scar as an impediment to regeneration in the central nervous system. In: Spinal Cord Reconstruction, pp. 163-196. Eds. C. C. Kao, R. P. Bunge and P. J. Reier. Raven Press, New York.

Rende, M., Muir, D., Ruoslathi, E., Hagg, T., Varon, S. and Manthorpe, M. (1992) Immunolocalization of ciliary neuronotrophic factor in adult rat sciatic nerve. Glia 5, 25-32. 
Richardson, P. M., Issa, V. M. K. and Shemie, S. (1982) Regeneration and retrograde degeneration of axons in the rat optic nerve. J. Neurocytol. 11, 949-966.

Ridet, J. L., Malhotra, S. K., Privat, A. and Gage, F. H. (1997) Reactive astrocytes: cellular and molecular cues to biological function. TINS 20, 570-577.

Risling, M., Fried, K., Linda, H., Carlstedt, T. and Cullheim, S. (1993) Regrowth of motor axons following spinal cord lesions, distribution of laminin and collagen in the CNS scar tissue. Brain Res. Bull. 30, 405-414.

Robinson, R. A. (1994) Immediate early gene expression in axotomized and regenerating retinal ganglion cells of the adult rat. Mol. Brain Res. 24, 43-54.

Rocamora, N., Massieu, L., Boddeke, H. W., Palacios, J. M. and Mengod, G. (1994) Differential regulation of the expression of nerve growth factor, brain-derived neurotrophic factor and neurotrophin-3 mRNAs in adult rat brain after intrahippocampal injection of quinolinic acid. Mol. Brain Res. 26, 89-98.

Roederer, E., Goldberg, N. H. and Cohen, M. J. (1983) Modification of retrograde degeneration in transected spinal axons of the lamprey by applied DC current. J. Neurosci. 3, 153-160.

Rosenberg, M. B., Friedman, T., Robertson, R. C., Tuszynski, M. H., Wolff, J. A., Breakefield, X. O. and Gage, F. H. (1988) Grafting genetically modified cells to the brain. Restorative effects of NGF expression. Science 242, 1575-1578.

Rossi, F., Wiklund, L., van der Want, J. J. L. and Strata, P. (1991) Reinnervation of cerebellar Purkinje cells by climbing fibers surviving a subtotal lesion of the inferior olive in the adult rat. I. Development of new collateral branches and terminal plexuses. J. Comp. Neurol. 308, 513-535.

Rossi, F., Jankovski, A. and Sotelo, C. (1995) Differential regenerative response of Purkinje cell and inferior olivary axons confronted with embryonic grafts: environmental cues versus intrinsic neuronal determinants. J. Comp. Neurol. 359, 663-677.

Rutkowski, J. L., Kirk, C. J., Lerner, M. A. and Tennekoon, G. I. (1995) Purification and expansion of human Schwann cells in vitro. Nature Med. 1, 80-83.

Saffran, B. N., Woo, J. E., Mobley, W. C. and Crutcher, K. A. (1989) Intraventricular NGF infusion in the mature rat brain enhances sympathetic innervation of cerebrovascular targets but fails to elicit sympathetic ingrowth. Brain Res. 492, 245-254.

Salonen, V., Peltonen, J., Royatta, M. and Virtanen, I. (1987) Laminin in traumatized peripheral nerve, basement membrane changes during degeneration and regeneration. J. Neurocytol. 16, 713-720.

Savio, T. and Schwab, M. E. (1990) Lesioned corticospinal tract axons regenerate in myelin-free rat spinal cord. Proc. Natl Acad. Sci. U.S.A. 87, 4130-4133.

Sawai, H., Clarke, D. B., Bray, G. M. and Aguayo, A. J. (1996) Brain-derived neurotrophic factor and neurotrophin-4/5 stimulate growth of axonal branches from regenerating retinal ganglion cells. J. Neurosci. 16, 3887-3894.

Schaaf, M. J., Hoetelmans, R. W., de Kloet, E. R. and Vreugdenhil, E. (1997) Corticosterone regulates expression of BDNF and trkB but not NT-3 and trkC mRNA in the rat hippocampus. J. Neurosci. Res. 48, 334-341.

Schachner, M. (1990) Functional implications of glial cell recognition molecules. Sem. Neurosci. 2, 497-507.

Schaden, H., Stürmer, C. A. O. and Bähr, M. (1994) GAP-43 immunoreactivity and axon regeneration in retinal ganglion cells of the rat. $J$. Neurobiol. 25, 1570-1578.

Schauwecker, P. E. and McNeill, T. H. (1995) Enhanced but delayed axonal sprouting of the commissural/associational pathway following a combined entorhinal cortex/fimbria fornix lesion. J. Comp. Neurol. 351, 453-464.

Schiffer, D., Giordana, M. T., Migheli, A., Giaccone, G., Pezzotta, S. and Mauro, A. (1986) Glial fibrillary acidic protein and vimentin in the experimental glial reaction of the rat brain. Brain Res. 374, 110-118.

Schmidt, R. A., Björklund, A. and Stenevi, U. (1981) Intracerebral grafting of dissociated CNS tissue suspensions, a new approach for neuronal transplantation to deep brain sites. Brain Res. 218, 347-356.

Schmidt-Kastner, R., Szymas, J. and Hossmann, K.-A. (1990) Immunohistochemical study of glial reaction and serum-protein extravasation in relation to neuronal damage in rat hippocampus after ischemia. Neurosci. 38, 527-540.

Schnell, L. and Schwab, M. E. (1990) Axonal regeneration in the rat spinal cord produced by an antibody against myelin-associated neurite growth inhibitors. Nature 343, 269-272.
Schnell, L. and Schwab, M. E. (1993) Sprouting and regeneration of lesioned corticospinal tract fibres in the adult rat spinal cord. Eur. J. Neurosci. 5, 1156-1171.

Schnell, L., Schneider, R., Kolbeck, R., Barde, Y.-A. and Schwab, M. E. (1994) Neurotrophin-3 enhances sprouting of corticospinal tract during development and after adult spinal cord lesion. Nature 367, 170-173.

Schreyer, D. J. and Jones, E. G. (1987) Growth of corticospinal axons on prosthetic substrates introduced into the spinal cord of neonatal rats. Dev. Brain Res. 35, 291-299.

Schwab, M. E. and Bartholdi, D. (1996) Degeneration and regeneration of axons in the lesioned spinal cord. Physiol. Rev. 76, 319-370.

Schwab, M. E. and Caroni, P. (1988) Oligodendrocytes and CNS myelin are nonpermissive substrates for neurite growth and fibroblast spreading in vitro. J. Neurosci. 8, 2381-2393.

Schwab, M. E. and Thoenen, H. (1985) Dissociated neurons regenerate into sciatic but not optic nerve explants in culture irrespective of neurotrophic factors. J. Neurosci. 5, 2415-2423.

Sendtner, M., Holtmann, B., Kolbeck, R., Thoenen, H. and Barde, Y. A. (1992) Brain-derived neurotrophic factor prevents the death of motoneurons in newborn rats after nerve section. Nature 360, 757-759.

Sendtner, M., Holtmann, B. and Highes, R. A. (1996) The response of motoneurons to neurotrophins. Neurochem. Res. 21, $831-841$.

Senut, M. C., Tuszynski, M. H., Raymon, H. K., Suhr, S. T., Liou, N. H., Jones, K. R., Reichardt, L. F. and Gage, F. H. (1995) Regional differences in responsiveness of adult CNS axons to grafts of cells expressing neurotrophin-3. Exp. Neurol. 135, 36-55.

Sharma, S. C., Jadhao, A. G. and Prasada, R. P. D. (1993) Regeneration of supraspinal projection neurons in the adult goldfish. Brain Res. 620, 221-228.

Shigematsu, K., Kamo, H., Akiguchi, I., Kimura, J., Kamemyama, M. and Kimura, H. (1989) Neovascularization in kainic acid-induced lesions of rat striatum. An immunohistochemical study with laminin. Brain Res. 501, 215-222.

Shine, H. D., Harcourt, P. G. and Sidman, R. L. (1985) Cultured peripheral nervous system cells support peripheral nerve regeneration through tubes in the absence of distal nerve stump. $J$. Neurosci. Res. 14, 393-401.

Sievers, J., Bamberger, C., Debus, O. M. and Lucius, R. (1995) Regeneration in the optic nerve of adult rats, influences of cultured astrocytes and optic nerve grafts of different ontogenetic stages. J. Neurocytol. 24, 783-793.

Skene, J. H. P. (1989) Axonal growth-associated proteins. Аnпи. Rev. Neurosci. 12, 127-156.

Sladek, J. R. and Shoulson, I. (1988) Neural transplantation, a call for patience rather than patients. Science 240, 1386-1388.

Smale, K. A., Doucette, R. and Kawaja, M. D. (1996) Implantation of olfactory ensheating cells in the adult rat brain following fimbria-fornix transection. Exp. Neurol. 137, 225-233.

Smith, G. M. and Miller, R. H. (1991) Immature type-1 astrocytes suppress glial scar formation, are motile and interact with blood vessels. Brain Res. 543, 111-122.

Smith, G. M. and Silver, J. (1996) Transplantation of Immature and Mature Astrocytes and Their Effect on Scar Formation in the Lesioned Central Nervous System, pp. 353-361. Elsevier Science, Amsterdam.

Smith, G. V. and Stevenson, J. A. (1988) Peripheral nerve grafts lacking viable Schwann cells fail to support central nervous system axonal regeneration. Exp. Brain Res. 69, 299-306.

Smith, G. M., Miller, R. H. and Silver, J. (1986) Changing role of forebrain astrocytes during development, regenerative failure, and induced regeneration upon transplantation. J. Comp. Neurol. 251, 23-43.

Smith, G. M., Rutishauser, U., Silver, J. and Miller, R. H. (1990) Maturation of astrocytes in vitro alters the extent and molecula basis of neurite outgrowth. Dev. Biol. 138, 377-390.

Snow, A. D., Lemmon, V., Carrino, D. A., Caplan, A. I. and Silver, J. (1990) Sulfated proteoglycans in astroglial barriers inhibit neurite outgrowth in vitro. Exp. Neurol. 109, 111-130.

Snow, D. M. and Letourneau, P. C. (1992) Neurite outgrowth on a step gradient of chondroitin sulfate proteoglycan (CS-PG). $J$. Neurobiol. 23, 322-336

Snyder, E. Y. and Senut, M.-C. (1997) The use of noneuronal cells for gene delivery. Neurobiol. Dis. 4, 69-102.

So, K.-F. and Aguayo, A. J. (1985) Lengthy regrowth of cut axons from ganglion cells after peripheral nerve transplantation into the retina of adult rats. Brain Res. 32, 349-354. 
Sosale, A., Robson, J. A. and Stelzner, D. J. (1988) Laminin distribution during corticospinal tract development and after spinal cord injury. Exp. Neurol. 102, 14-22.

Steward, O., Lynch, G. and Cotman, C. (1973) Histochemical detection of orthograde degeneration in the central nervous system of the rat. Brain Res. 54, 65-73.

Stichel, C. C. and Müller, H. W. (1994a) Extensive and long-lasting changes of glial cells following transection of the postcommissural fornix in the adult rat. Glia 10, 89-100

Stichel, C. C. and Müller, H. W. (1994b) Relationship between injury-induced astrogliosis, laminin expression and axonal sprouting in the adult rat brain. J. Neurocytol. 23, 615-630.

Stichel, C. C., Kappler, J., Junghans, U., Koops, A., Kresse, H. and Müller, H. W. (1995a) Differential expression of the small chondroitin/dermatan sulfate proteoglycans decorin and bíglycan after injury of the adult rat brain. Brain Res. 704, 263274.

Stichel, C. C., Wunderlich, G., Schwab, M. E. and Müller, H. W. (1995b) Clearance of myelin constituents and axonal sprouting in the transected postcommissural fornix of the adult rat. Eur. J. Neurosci. 7, 401-411.

Stichel, C. C., Lips, K., Wunderlich, G. and Müller, H. W. (1996) Reconstruction of transected postcommissural fornix in adult rat by Schwann cell suspension grafts. Exp. Neurol. 140, 21-36.

Stichel, C. C., Lips, K., Wunderlich, G. and Müller, H. W. (1997) Schwann cell suspension grafts promote reconstruction of transected postcommissural fornix in the adult rat. In: Molecular Signaling and Regulation in Glial Cells, pp. 357-366. Eds. G. Jeserich, H. H. Althaus, C. Richter-Landsberg and R. Heumann. Springer, Berlin.

Stichel, C. C., Niermann, H., Lausberg, F., Hermanns, S., d'Urso, D., Servos and Müller, H. W. (1998) Axonal regeneration through a modified CNS lesion scar. Soc. Neurosci Abstr. Abstr. 24 (in press)

Stoll, G., Trapp, B. D. and Griffin, J. W. (1989) Macrophage function during Wallerian degeneration of rat optic nerve, clearance of degenerating myelin and Ia expression. J. Neurosci. 9, 2327 2335.

Streit, W. J., Graeber, M. B. and Kreutzberg, G. W. (1988) Functional plasticity of microglia, a review. Glia 1, 301-307.

Stürmer, C. A. O., Bastmeyer, M., Bähr, M., Strobel, G. and Paschke, K. (1992) Trying to understand axonal regeneration in the CNS of fish. J. Neurobiol. 23, 537-559.

Szele, F. G., Alexander, C. and Chesselet, M.-F. (1995) Expression of molecules associated with neuronal plasticity in the striatum after aspiration and thermocoagulatory lesions of the cerebral cortex in adult rats. J. Neurosci. 15, 4429-4448.

Takamiya, Y., Kohsaka, S., Toya, S. Otani, M and Tsukada, Y. (1988) Immunohistochemical studies on the proliferation of reactive astrocytes and the expression of cytoskeletal proteins following brain injury in rats. Dev. Brain Res. 38, 201-210.

Taylor, J., Pesheva, P. and Schachner, M. (1993) Influence of janusin and tenascin on growth cone behavior in vitro. J. Neurosci. Res 35, 347-362.

Tello, F. (1911) La influencia del neurotropismo en la regeneracion de los centros nerviosos. Trab. Lab. Invest. Biol. 9, 123-159.

Thanos, S. (1992) Adult retinofugal axons regenerating through peripheral nerve grafts can restore the light-induced pupilloconstriction reflex. Eur. J. Neurosci. 4, 691-699.

Thanos, S. and Vanselow, J. (1989) Adult retinal ganglion cells retain the ability to regenerate their axons up to several weeks after axotomy. $J$. Neurosci. Res. 22, 144-149.

Thanos, S., Mey, J. and Wild, M. (1993) Treatment of the adult retina with microglia-suppressing factors retards axotomyinduced neuronal degradation and enhances axonal regeneration in vivo and in vitro. J. Neurosci. 13, 455-466.

Thanos, S., Naskar, R. and Heiduschka, P. (1997) Regenerating ganglion cell axons in the adult rat establish retinofugal topography and restore visual function. Exp. Brain Res. 114, 483491.

Thomas, W. E. (1992) Brain macrophages, evaluation of microglia and their function. Brain Res. Rev. 17, 61-74.

Timmusk, T. and Metsis, M. (1994) Regulation of BDNF promoters in the rat hippocampus. Neurochem. Int. 25, 11-15.

Timpl, R. and Brown, J. (1996) Supramolecular assembly of basement membranes. Curr. Opin. Cell. Biol. 8, 618-624.

Trimmer, P. A. and Wunderlich, R. E. (1990) Changes in astroglial scar formation in rat optic nerve as a function of development. J. Comp. Neurol. 296, 359-378.

Tuszynski, M. H., Gabriel, K., Gage, F. H., Suhr, S., Meyer, S. and Rosetti, A. (1996) Nerve growth factor delivery by gene transfer induces differential outgrowth of sensory, motor, and noradrenergic neurites after adult spinal cord injury. Exp. Neurol. 137, 157-173.

Tuszynski, M. H., Peterson, D. A., Ray, J., Baird, A., Nakahara, Y. and Gage, F. H. (1994) Fibroblasts genetically modified to produce nerve growth factor induce robust neuritic ingrowth after grafting to the spinal cord. Exp. Neurol. 126, 1-14.

Tymianski, M. and Tator, C. H. (1996) Normal and abnormal calcium homeostasis in neurons, a basis for the pathophysiology of traumatic and ischemic central nervous system injury. Neurosurgery 38, 1176-1195.

Van den Berg, L. H., Bär, P. R., Sodaar, P., Mollee, I., Wokke, J. J. H. and Logtenberg, T. (1995) Selective expansion and longterm culture of human Schwann cells from sural nerve biopsies. Ann. Neurol. 38, 674-678.

Varon, S. and Conner, J. M. (1994) Nerve growth factor in CNS repair. J. Neurotrauma 11, 473-487.

Vaudano, E., Campbell, G., Anderson, P. N., Davies, A. P. Woolhead, C., Schreyer, D. J. and Lieberman, A. R. (1995) The effects of a lesion or a peripheral nerve graft on GAP43 upregulation in the adult rat brain, an in situ hybridization and immunocytochemical study. J. Neurosci. 15, 3594-3611.

Verhaagen, J., Hermens, W. T. J. M. C., Dijkhuizen, P. A., Holtmaat, A. J. G. D. and Gispen, W. H. (1996) Use of viral vectros to promote neuroregeneration. Clin. Neurosci. 3, 275283.

Vidal-Sanz, M., Bray, G. M., Villegas-Pérez, M. P., Thanos, S. and Aguayo, A. J. (1987) Axonal regeneration and synapse formation in the superior colliculus by retinal ganglion cells in the adult rat. J. Neurosci. 7, 2894-2909.

Vinores, S. A and Herman, M. M. (1993) Phagocytosis of myelin by astrocytes in explants of adult rabbit cerebral white matter maintained on Gelfoam matrix. J. Neuroimmunol. 43, 169-176.

Wang, J. J., Chuah, M. I., Yew, D. T. W., Leung, P. C. and Tsang, D. S. C. (1995a) Effects of astrocyte implantation into the hemisected adult rat spinal cord. Neuroscience 65, 973-981.

Wang, M. J., Friedmann, T. and Johnson, P. A. (1995b) Differentiation of PC12 cells by infection with an HSV-1 vector expressing nerve growth factor. Gene Ther. 2, 323-335.

Watanabe, M. and Fukuda, Y. (1997) Proportions of ON-center versus OFF-center cells in retinal ganglion cells with regenerated axons of adult cats. Exp. Neurol. 143, 117-123.

Watanabe, E., Aono, S., Matsui, F., Yamada, Y., Naruse, I. and Oohira, A. (1995) Distribution of brain-specific proteoglycan, neurocan, and the corresponding mRNA during the formation of barrels in the rat somatosensory cortex. Eur. J. Neurosci. 7, 547-554.

Weibel, D., Cadelli, D. and Schwab, M. E. (1994) Regeneration of lesioned rat optic nerve fibers is improved after neutralization of myelin-associated neurite growth inhibitors. Brain Res. 642 , 259-266.

Wells, M. R., Kraus, K., Batter, D. K., Blunt, D. G., Weremowitz, J., Lynch, S. E., Antoniades, H. N. and Hansson, H.-A. (1997) Gel matrix vehicles for growth factor application in nerve gap injuries repaired with tubes, a comparison of biomatrix, collagen and methylcellulose. Exp. Neurol. 146, 395402.

Wendt, J. S. and Ayyad, K. A. (1987) Is there regeneration of cholinergic axons through traumatic scar tissue in adult mammalian brain? Exp. Neurol. 95, 65-75.

Wichmann, T., Vitek, J. L. and DeLong, M. R. (1996) Parkinson's disease and the basal ganglia, lessons from the laboratory and from neurosurgery. The Neuroscientist 1, 236-244.

Wictorin, K., Brundin, P., Sauer, H., Lindvall, O. and Björklund, A. (1992) Long distance directed axonal growth from human dopaminergic neuroblasts implanted along the nigrostriatal pathway in 6-hydroxydopamine lesioned adult rats. J. Comp. Neurol. 323, 475-494.

Wilkin, G. P., Marriott, D. R. and Cholewinski, A. J. (1990) Astrocyte heterogeneity. TINS 13, 43-46.

Williams, L. R. (1991) Hypophagia is induced by intracerebroventricular administration of nerve growth factor. Exp. Neurol. 113, 31-37.

Windle, W. F., Clemente, C. D. and Chambers, W. W. (1951) Regeneration in the spinal cord of the cat and dog. Arch. Neurol. Psychiat. 65, 261-262.

Winn, S. R., Lindner, M. D., Lee, A., Haggett, G., Francis, J. M. and Emerich, D. F. (1996) Polymer-encapsulated genetically modified cells continue to secrete human nerve growth factor for over one year in rat ventricles, behavioral and anatomical consequences. Exp. Neurol. 140, 126-138.

Wizenmann, A., Thies, E., Klostermann, S., Bonhoeffer, F. and Bähr, M. (1993) Appearance of target-specific guidance infor- 
mation for regenerating axons after CNS lesions. Neuron 11, 975-983.

Wolburg, H. and Kästner, R. (1984) Is the architecture of astrocytic membrane crucial for axonal regeneration in the central nervous system? Naturwissenschaften 71, 484-485.

$\mathrm{Wu}, \mathrm{W}$. (1996) Potential roles of gene expression change in adult rat spinal motoneurons following axonal injury, a comparison among c-jun, low-affinity nerve growth factor receptor (LNGFR) and nitric oxide synthase (NOS). Exp. Neurol. 141, 190-200.

Wunderlich, G., Stichel, C. C., Schroeder, W. O. and Müller, H. W. (1994) Transplants of immature astrocytes promote axonal regeneration in the adult rat brain. Glia 10,49-58.

Xu, X. M., Guénard, V., Kleitman, N., Aebischer, P. and Bunge, M. B. (1995a) A combination of BDNF and NT-3 promotes supraspinal axonal regeneration into Schwann cell grafts in adult thoracic spinal cord. Exp. Neurol. 134, 261-272.

Xu, X. M., Guénard, V., Kleitman, N. and Bunge, M. B. (1995b) Axonal regeneration into Schwann cell-seeded guidance channels grafted into transected adult rat spinal cord. J. Comp. Neurol. 351, 145-160.

Yan, Q., Radeke, M. J., Matheson, C. R., Talvenheimo, J., Welcher, A. A. and Feinstein, S. C. (1997)
Immunocytochemical localization of TrkB in the central nervous system of the adult rat. J. Comp. Neurol. 378, 135-157.

Yen, L. and Kalb, R. G. (1995) Recovery from spinal cord injury, new approaches. The Neuroscientist 1, 321-327.

Zafra, F., Castren, E., Thoenen, H. and Lindholm, D. (1991) Interplay between glutamate and gamma-aminobutyric acid transmitter systems in the physiological regulation of brain-derived neurotrophic factor and nerve growth factor synthesis in hippocampal neurons. Proc. Natl Acad. Sci. U.S.A. 88, 1003710041.

Zhang, Y., Anderson, P. N., Campbell, G., Mohajeri, H., Schachner, M. and Lieberman, A. R. (1995) Tenascin-C expression by neurons and glial cells in the rat spinal cord, changes during postnatal development and after dorsal root or sciatic nerve injury. J. Neurocytol. 24, 585-601.

Zhou, X. F. and Rush, R. A. (1994) Localization of neurotrophin3-like immunoreactivity in the rat central nervous system. Brain Res. 643, 162-172.

Zwimpfer, T., Aguayo, A. J. and Bray, G. M. (1992) Synapse formation and preferential distribution in the granule cell layer by regenerating retinal ganglion cell axons guided to the cerebellum of adult hamsters. J. Neurosci. 12, 1144-1159. 